\title{
Mental health outcomes in times of economic recession: a systematic literature review
}

\author{
Diana Frasquilho ${ }^{1}$, Margarida Gaspar Matos ${ }^{2}$, Ferdinand Salonna ${ }^{3 *}$, Diogo Guerreiro ${ }^{4}$, Cláudia C. Storti ${ }^{5}$,
} Tânia Gaspar ${ }^{6}$ and José M. Caldas-de-Almeida ${ }^{7}$

\begin{abstract}
Background: Countries in recession experience high unemployment rates and a decline in living conditions, which, it has been suggested, negatively influences their populations' health. The present review examines the recent evidence of the possible association between economic recessions and mental health outcomes.

Methods: Literature review of records identified through Medline, PsycINFO, SciELO, and EBSCO Host. Only original research papers, published between 2004 and 2014, peer-reviewed, non-qualitative research, and reporting on associations between economic factors and proxies of mental health were considered.

Results: One-hundred-one papers met the inclusion criteria. The evidence was consistent that economic recessions and mediators such as unemployment, income decline, and unmanageable debts are significantly associated with poor mental wellbeing, increased rates of common mental disorders, substance-related disorders, and suicidal behaviours.

Conclusion: On the basis of a thorough analysis of the selected investigations, we conclude that periods of economic recession are possibly associated with a higher prevalence of mental health problems, including common mental disorders, substance disorders, and ultimately suicidal behaviour. Most of the research is based on cross-sectional studies, which seriously limits causality inferences. Conclusions are summarised, taking into account international policy recommendations concerning the cost-effective measures that can possibly reduce the occurrence of negative mental health outcomes in populations during periods of economic recession.
\end{abstract}

Keywords: Economic recession, Mental disorders, Mental health, Substance-related disorders, Suicide, Unemployment

\section{Background}

Economic recessions have been estimated to significantly affect the population's health and wellbeing, which applies, in particular, to vulnerable groups of people [1-5]. In countries that have been hardest hit by the latest recession, which started in 2007, the living and working conditions have substantially worsened [6]. Work became more precarious and unemployment rates increased as a result of the slowdown in global growth and consequent deterioration of the labour markets [7]. For instance,

\footnotetext{
* Correspondence: ferdinand.salonna@upol.cz

${ }^{3}$ Institute of Active Lifestyle, Faculty of Physical Culture, Palacky University

Olomouc, Olomouc, Czech Republic

Full list of author information is available at the end of the article
}

almost half of the citizens of Europe reported knowing someone who had lost his/her job as a direct result of the crisis [8]. Rates of involuntary part-time employment have also been rising since the beginning of the recession [9]. Overall, people are more fearful about losing their employment [8] since competition for jobs is rising and finding work quickly is perceived as unlikely. It is estimated that labour markets will take time to improve even though there are prospects for economic recovery [6]. Levels of poverty and social exclusion have worsened, mainly in groups that were already at risk [10]. During this recession, more people have been reporting being at risk of being unable to cope with unexpected expenses and even facing 
difficulties with paying ordinary bills or buying food over the coming year [8].

It is known that the health of populations is shaped by the socioeconomic context, welfare systems, labour markets, public policies, and demographic characteristics of countries [4]. There are strong reasons to believe that changes in these key determinants may be reflected in the mental wellbeing of populations [11]. Therefore, mental health should be a health area regarded as possibly vulnerable during a recession [12], especially if mental disorders were already highly prevalent even before the crisis began [13]. Nonethless, some authors have argued that associations between contracting economies and levels of well-being may show mixed patterns of both positive and negative impacts [14]. However, this current recession is likely to aggravate and boost mental health problems through growing socioeconomic risk factors such as unemployment, financial strain, debts, and job-related problems [3]. People facing these major life changes are more prone to mental ill-health [15-18]. It has also been theorised that economic pressure and unemployment have a devastating impact on families, in particular children, since the family is the most important context for their healthy development $[19,20]$.

This paper intends to cover the main sources and types of recent evidence on populations' mental health outcomes in times of economic recession. Specifically to summarize the mental health outcomes and the socioeconomic determinants most frequently addressed by the literature on economic recessions, which groups of people seem to be the most vulnerable, and to determine possible research needs.

\section{Methods}

\section{Search strategy and definition of terms}

A systematic search was performed in Medline, PsycINFO, SciELO, and EBSCO Host. The keywords used for reference tracing were derived from Medical Subject Headings $(\mathrm{MeSH})$ in combination with key terms used in other reviews $[2,3,5,21,22]$.

Two sets of keywords were then used and combined: 1) Recession and socioeconomic terms - "Economic recession" OR "Financial crisis" OR "Recession" OR "Unemployment" OR "Socioeconomic deprivation"; combined with 2) Mental health outcomes - "Mental health" OR "Mental disorders" OR "Suicide" OR "Substance-Related Disorders".

Regarding the recession and socioeconomic terms, besides the logical use of the words "economic recession" and its synonyms, the word "unemployment" was used as it is a widely recognised countercyclical variable, i.e. a phenomenon that increases in recessions [23]. The term "socioeconomic deprivation" was used, on one hand because it is a broad term that includes the characteristics of both social and economic vulnerability that are expected to increase in periods of recession [24], and on the other hand, because of its indisputable negative effect on health $[5,11]$. Concerning the mental health outcomes, in addition to "mental health", the term "mental disorders" was used because it is a MeSH term that encompasses "all psychiatric illness or diseases manifested by breakdowns in the adaptational process expressed primarily as abnormalities of thought, feeling, and behaviour producing either distress or impairment of function". Although "mental disorders" is a broad term, it does not include suicide, which is known to be associated with major mental health problems [25]. Therefore a specific keyword for that was entered. The term "substance-related disorders" was also included, because using the broad term "mental disorders" did not retrieve papers with clear specific results and this was a MeSH term used in other reference works [26].

\section{Eligibility criteria and data extraction}

Two reviewers independently screened all the titles and abstracts. The final articles in this review are a consensual reflection of both reviewers. They only considered studies for inclusion that were original research papers, peer-reviewed, published between 2004 and 2014, written in English or Portuguese, and showing associated results between recession or socioeconomic terms and mental health outcomes. Moreover, the authors excluded all duplicates, small sample investigations $(<1000$ except for casecontrol studies) for precision reasons and strength of effect sizes [27], research that did not employ validated instruments or used an inappropriate methodology regarding the associations under consideration (e.g. ambiguous variables under study, poor construct validity, and drawing of conclusions without statistical support), and qualitative research. The data extraction from each study was based on the following variables: the setting and country, the sample ( $\mathrm{N}$ and age), the years examined, the mental health outcome(s) and the socioeconomic determinant(s), and the key associations or effects found. In general, we found significant disparities in the methods, data collection procedures, analyses, and contexts of existing studies that complicated direct comparison of results among studies. Because of this diversity of metrics and outcome variables, it was impossible to apply statistical criteria to the studies and for that reason it was not appropriate to perform meta-analysis of the results.

\section{Mental health outcomes associated with economic recessions}

We organised the main results by mental health outcomes and the socioeconomic determinants most frequently addressed by the literature, based on the quality of study design (cohort, case-control, cross-sectional and ecological). The mental health outcomes were clustered into four main groups: 1) psychological wellbeing (measured 
by continuous variables of mental health distress, selfrated health, and wellbeing or quality of life variables); 2) common mental disorders (assessed by caseness for depression, anxiety, and somatoform disorders); 3) problems related to substance-related disorders (reports on smoking, patterns of alcohol consumption, drug use, and substancerelated harms), and 4) reports on suicidal behaviours (suicide mortality, parasuicidal behaviour, suicidal ideation, and attempts). The socioeconomic determinants retrieved were clustered into three groups by: 1 ) inter-time variables (preand post-economic recession changes); 2) macroeconomic indicators (rates of unemployment, GDP, home foreclosure rates), and 3) individual-level indicators (employment status, psychosocial job quality and security, household income, perceived financial strain or security, perceived economy/recession stress, deprivation, indebtedness, housing payment problems, socioeconomic status).

\section{Results}

\section{Study selection results}

At the beginning, 20,502 studies were identified and were first filtered on the basis of being original peer-reviewed research papers and published between 2004 and 2014. The remaining 7351 papers were then screened by two independent reviewers through their titles and abstracts, and the subsequent filtering was performed on the basis of the following inclusion criteria: not being duplicates, written in English or Portuguese, were non-qualitative research, and reported associations between recession or socioeconomic terms and mental health outcomes. The full texts of 183 studies were then analysed. The number of papers excluded was a consequence of combinations of search keywords such as "crisis" and "mental health" or "suicide" that resulted in papers not relevant to the study objective. From the analysis of the 183 full texts, the investigators further excluded studies that used an inappropriate methodology regarding the associations between economic recession and mental health outcomes, including non-validated instruments, or used small samples $(<1000$, with the exception of case-control studies). After the previously described multistep selection method, 101 papers were used for the present review. Figure 1 shows the progress of selection for the study and the number of articles at each selection stage.

\section{Research designs}

Table 1 summarizes the main features of the retrieved studies. Two studies used case-control design, 30 were cohort studies, 40 were cross-sectional studies or repeated cross-sectional studies, one used a mixed cross-sectional and case-control design, and 28 were ecological studies.

\section{Samples and geographical allocation}

More than half (66) of the total of 101 studies used national population samples. Out of these 66,58 were general population samples and the rest were focusing on specific populations. Two used working populations, two used unemployed populations, two used samples of adolescents, one used a sample of patients attending primary care centres, and one used a sample of older adults. Furthermore, 16 studies used crossnational population samples, of which 11 were general population samples and 5 focused only specific populations. Two studies were samples of children and adolescents; one was a sample of working population; one used a sample of patients attending primary care centres, and one used samples of older adults. An additional 19 studies used community or regional samples. Out of these 19, 10 studies used general population, 3 used samples of workers, 1 used a sample of unemployed adults, 2 used samples of adolescents, 1 used a sample of children and parents, 1 used a sample of older adults, and 1 used a sample of hospital patients.

In terms of geographical allocation, 61 studies were conducted in Europe (7 studies were cross-European, 2 studies used samples from both Greece and Poland, and both Denmark and Sweden, 15 used samples from the UK, 8 from Greece, 7 from Sweden, 7 from Spain, 4 from Italy, 3 from Finland, 2 from Iceland, and 1 population sample each from France, Germany, Hungary, Portugal, Slovakia, and Slovenia). Eighteen studies have North American population samples (15 from USA and 3 from Canada); 7 studies were from Australasia countries (five Australian and two from New Zealand). Two studies were South American, one from Argentina and Brazil, and six studies were from Asian countries (three from South Korea, two from Japan, and one study from Hong Kong). In addition, there were seven multicentre studies that used cross continent population samples from various countries.

\section{Pre and post-economic recession changes in psychological wellbeing}

Studies comparing the data to pre-recession periods show a consistent aggravation of the mental health status of the populations involved (Table 2).

A longitudinal study from Greece showed that mental health and self-rated health were negatively affected by unemployment during the economic recession (2008-2013), especially among unemployed individuals [28]. A similar result was found in Italy, where the inequalities regarding self-reported health between workers and unemployed individuals were amplified after the onset of the recession [29].

Repeated cross-sectional studies from Greece also showed that the recession period was associated with a significant deterioration of the population's self-reported health and increased odds of poor health when compared 


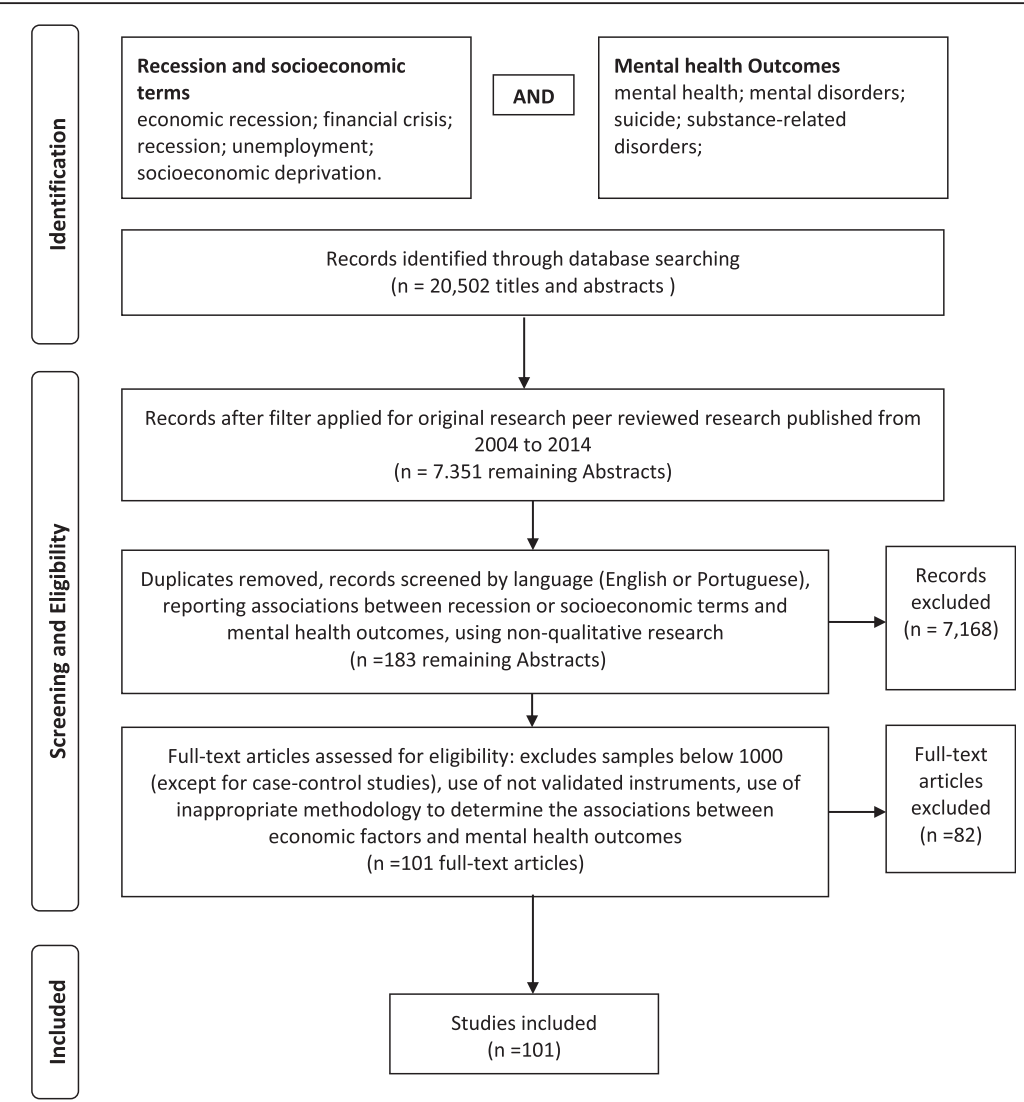

Fig. 1 Flow diagram of the multistep selection method

Table 1 Summary of the main features of retrieved studies

\begin{tabular}{ll}
\hline Studies research design & 2 \\
Case-control & 30 \\
Cohort & 41 \\
Cross-sectional & 28 \\
Ecological & \\
Samples & 16 \\
Cross-national population samples & 66 \\
National population samples & 19 \\
Regional/community samples & \\
Geographical allocation of studies' samples & 61 \\
EU & 18 \\
North America (USA and Canada) & 7 \\
Australasia (Australia and New Zealand) & 6 \\
Asia (China, Japan, South Korea) & 2 \\
South America (Argentina and Brazil) & 7 \\
Multicentre &
\end{tabular}

to control populations [30, 31]. English and Spanish repeated cross-sectional studies indicated that the prevalence of psychological distress significantly increased during the recession period, with a greater impact on men compared to women [32, 33]. However, women also reported increased mental distress during the recession, according to a repeated cross-sectional survey from Sweden [34]. In Japan, comparable surveys before and after the economic recession period showed reports of an increase in poor health across people of all socioeconomic ranks [35].

\section{Pre and post-economic recession changes in rates of common mental disorders}

Regarding morbidity rates for common mental disorders, longitudinal data from Iceland presented aggravated stress levels among the population, though only significant for women and especially if unemployed [36].

Greek comparable data from before and after the recession exhibited a statistically significant rise in the prevalence of depression [37, 38]. In Spain, evidence displayed a risk of suffering from depression during a recession that was almost three times higher than before [39]. Similar evidence was also found in Canada and Hong Kong [40, 41]. The same Spanish study also showed an increase in the 
Table 2 Characteristics of studies included in the review comparing the data to pre-recession periods and mental health outcomes, 2004-2014

\begin{tabular}{|c|c|c|c|c|c|c|c|c|}
\hline Study & Setting & Study design & $\begin{array}{l}\mathrm{N} \\
\text { Year } \\
\text { Age }\end{array}$ & $\begin{array}{l}\text { Socioeconomic } \\
\text { determinants }\end{array}$ & $\begin{array}{l}\text { Mental health } \\
\text { outcomes }\end{array}$ & Associations/Effects & Strengths & Limitations \\
\hline [28] & $\begin{array}{l}\text { National population } \\
\text { sample, Greece }\end{array}$ & Cohort & $\begin{array}{l}17,713 \\
(2008-2013) \\
\text { Mean age } \\
39.41 y \\
(S D=8.83)\end{array}$ & $\begin{array}{l}\text { Inter-time Variables } \\
\text { Psychosocial/economic } \\
\text { indicators } \\
\text { Pre- and post- recession } \\
\text { period } \\
\text { Employment Status }\end{array}$ & $\begin{array}{l}\text { Psychological } \\
\text { Well-being } \\
\text { Mental health } \\
\text { (CES-D scale) } \\
\text { Self-rated health }\end{array}$ & $\begin{array}{l}\text { In the period 2008-2013 } \\
\text { unemployed people } \\
\text { faced more impaired } \\
\text { health }(3.21 \text { vs } 2.48, \\
\mathrm{t}=8.34, p=0.00) \text { and } \\
\text { mental health than } \\
\text { did employed people } \\
(12.67 \text { vs } 9.39, \mathrm{t}=12.28, \\
p=0.00) \text {. These health } \\
\text { differences between } \\
\text { unemployed and } \\
\text { employed individuals } \\
\text { were smaller in 2008-2009 } \\
\text { than in 2010-2013. }\end{array}$ & $\begin{array}{l}\text { Temporal order } \\
\text { of exposures, } \\
\text { confounders, and } \\
\text { the outcome under } \\
\text { consideration affected } \\
\text { all participants at the } \\
\text { same time, producing } \\
\text { stronger causal } \\
\text { conclusions. The } \\
\text { results indicate a } \\
\text { relationship between } \\
\text { unemployment and } \\
\text { health/mental health. }\end{array}$ & $\begin{array}{l}\text { The impact of economic } \\
\text { recessions varies across } \\
\text { cultures and time } \\
\text { periods; thus, the } \\
\text { generalisability of the } \\
\text { findings may be } \\
\text { considerably limited } \\
\text { by the uniqueness of } \\
\text { the Greek situation. }\end{array}$ \\
\hline [29] & $\begin{array}{l}\text { National population } \\
\text { sample, Italy }\end{array}$ & Cohort & $\begin{array}{l}37,782 \\
(2006-2010) \\
15-64 y\end{array}$ & $\begin{array}{l}\text { Inter-time Variables } \\
\text { Psychosocial/economic } \\
\text { indicators } \\
\text { Pre- and post- recession } \\
\text { period } \\
\text { Employment Status }\end{array}$ & $\begin{array}{l}\text { Psychological } \\
\text { Well-being } \\
\text { Self-rated health }\end{array}$ & $\begin{array}{l}\text { Temporary workers, } \\
\text { first job seekers and } \\
\text { unemployed individuals } \\
\text { all perceive their health } \\
\text { as being worse than } \\
\text { permanent workers } \\
\text { do.The health inequalities } \\
\text { between permanent } \\
\text { workers and the } \\
\text { unemployed rose, } \\
\text { especially for males } \\
\text { and young people, } \\
\text { after the economic } \\
\text { recession. }\end{array}$ & $\begin{array}{l}\text { The temporal order } \\
\text { of the exposures, } \\
\text { confounders, and } \\
\text { the outcome under } \\
\text { consideration affected } \\
\text { all the participants at } \\
\text { the same time, } \\
\text { producing stronger } \\
\text { causal conclusions. }\end{array}$ & $\begin{array}{l}\text { The impact of economic } \\
\text { recessions varies across } \\
\text { cultures and time } \\
\text { periods; thus, } \\
\text { generalising findings } \\
\text { may be reasonably } \\
\text { limited by the } \\
\text { uniqueness of the } \\
\text { Italian social system. }\end{array}$ \\
\hline [31] & $\begin{array}{l}\text { National population } \\
\text { samples from Greece } \\
\text { and Poland }\end{array}$ & $\begin{array}{l}\text { Repeated } \\
\text { cross-sectional } \\
\text { Case-control }\end{array}$ & $\begin{array}{l}54,120 \text { cases } \\
136,952 \\
\text { controls } \\
(2006-2009)\end{array}$ & $\begin{array}{l}\text { Inter-time Variables } \\
\text { Pre- and post-recession } \\
\text { period }\end{array}$ & $\begin{array}{l}\text { Psychological } \\
\text { Well-being } \\
\text { Self-reported } \\
\text { health }\end{array}$ & $\begin{array}{l}\text { Relative to the control } \\
\text { population (Poland), } \\
\text { Greece experienced } \\
\text { a significantly bigger } \\
\text { increase in the odds } \\
\text { of poor health after } \\
\text { the crisis (OR }=1.16 \text {; } \\
95 \% \mathrm{Cl} 1.04-1.29 \text { ) }\end{array}$ & $\begin{array}{l}\text { This study benefits } \\
\text { from having a control } \\
\text { group and cross- } \\
\text { national design.The } \\
\text { study is composed of } \\
\text { comparable surveys } \\
\text { across two time points, } \\
\text { before and after the } \\
\text { onset of the recession. }\end{array}$ & $\begin{array}{l}\text { Its cross-sectional } \\
\text { design removes the } \\
\text { possibility of causal } \\
\text { inference.Data is } \\
\text { derived from 2006- } \\
2009 \text { and the crisis } \\
\text { started in } 2008 \text { so } \\
\text { the long-term effects } \\
\text { of the recession could } \\
\text { not be investigated. }\end{array}$ \\
\hline [30] & $\begin{array}{l}\text { National population } \\
\text { sample, Greece }\end{array}$ & $\begin{array}{l}\text { Repeated } \\
\text { cross-sectional }\end{array}$ & $\begin{array}{l}10,572 \\
(2006) \\
(2011) \\
>18 \text { years }\end{array}$ & $\begin{array}{l}\text { Inter-time Variables } \\
\text { Pre- and post- recession } \\
\text { period }\end{array}$ & $\begin{array}{l}\text { Psychological } \\
\text { Well-being } \\
\text { Self-reported } \\
\text { health }\end{array}$ & $\begin{array}{l}\text { Self-reported good } \\
\text { health deteriorated } \\
\text { from } 71 \% \text { in } 2006 \\
\text { to } 68.8 \% \text { in } 2011 \\
(P<0.05) \text {. }\end{array}$ & $\begin{array}{l}\text { The study is composed } \\
\text { of comparable surveys } \\
\text { across two time } \\
\text { periods (pre- and post- } \\
\text { recession). }\end{array}$ & $\begin{array}{l}\text { Its cross-sectional } \\
\text { design removes the } \\
\text { possibility of causal } \\
\text { inference. It is limited } \\
\text { to } 2011 \text {. }\end{array}$ \\
\hline
\end{tabular}


Table 2 Characteristics of studies included in the review comparing the data to pre-recession periods and mental health outcomes, 2004-2014 (Continued)

[32] National population

sample, England,

UK

$\begin{array}{ll}\text { cross-sectional } & (199) \\ & (2010)\end{array}$

106,985

(2010)

ter-time Variables

Pre- and post- recession

period$$
\text { 25-64 y }
$$

[33] National population sample, Spain

Repeated

16,616

(2012)

Psychosocial/economic

indicators

period

Employment Status
[34] Regional population sample, Working-age Sweden

$\begin{array}{ll}\text { Repeated } & 27,994 \\ \text { cross-sectional } & (2006) \\ & 22,639 \\ & (2010) \\ & 18-64 \text { y }\end{array}$

Inter-time Variables

Psychosocial/economic

indicators

Pre- and post- recession

period

Employment Status

\section{Pychological \\ Nell-being \\ distress (GHQ-12)}

Age-sex adj GHQ-12 caseness increased $13.7 \%(95 \%$ C $12.9-14.5 \%$ ) in 2008 to $16.4 \%(95 \% \mathrm{Cl}$ : 14.9-17.9\%) in 2009 and $15.5 \%(95 \% \mathrm{Cl}$ : 14.4-16.7\%) in 2010. Women only had a greater prevalence from 1991 until the recession, but men showed an increase over the period.

Psychological Well-being Mental health distress (GHQ-12)

Results found a

increase in the

prevalence of poor

mental health among

men (prevalence

ratio $=1.15,95 \% \mathrm{Cl}$

1.04-1.26], especially

among those aged

35-54 years, and a

slight decrease for

women between
2006/07 and 2011/12

There was a larger

impact among the

unemployed.

Psychological

Well-being

Mental health

distress (GHQ-12)

Mental distress increased

among women of all

types of employment

status between 2006

and 2010, but more

so among unemployed

women, OR 2.65 (CI $95 \%$

$2.17-3.23$ ) in 2006 and
OR 2.81 (Cl $95 \% 2.20-3.58$ )

in 2010.
Uses a continuous

symptoms.Large possibily of causal

nationally period of time; the

representative dataset long-term effects

surveyed two times. of the recession

could not be

investigated.

The study is

composed of

design removes the

comparable surveys possibility of causa

across two time inference.Limited

points before and period of time (2012)

after the economic the long-term effects

recession

of the recession could

period.Representative not be investigated.

sample
The study is

composed of

comparable surveys

across multiple time

points before and

after the economic

recession period.

Its cross-sectional inference.Data is

derived from 2006-

2010 and the crisis

the long term effects

of the recession could

not be investigated.

The sample is composed

only of women. 
Table 2 Characteristics of studies included in the review comparing the data to pre-recession periods and mental health outcomes, 2004-2014 (Continued)

[35] National population sample, Japan

\section{Repeated} Inter-time Variables

[36]

$\begin{array}{lll}\text { National population } & \text { Cohort } & 9807 \\ \text { sample, lceland } & & (2007) \\ & 5439 \\ & (2009)\end{array}$

[37] National population sample, Greece

$\begin{array}{ll}\text { Repeated } & 2197 \\ \text { cross-sectional } & (2008) \\ & 2256 \\ & (2011) \\ & 18-69 y\end{array}$
(1986-198 150,016 20-60 y Psychosocial/economic indicators period Employment status/Income

9807

(2007)

(2009)

Psychosocial/economic

indicators

Pre- and post-recession

period

Employment Status

Sychological
Well-being
Self-reported
health

sychological

Self-reported

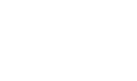

common

Mental

Disorders

Psychological

stress (PSS-4)

Inter-time Variables

Psychosocial/economic

indicators

$18-69 y$ post- recession

Perceived financial strain
The OR for poor self-rated

health (95\% CI) among

middle-class people

compared with the

highest class was 1.02

(0.92-1.14) before the

crisis and increased to

$1.14(1.02-1.29)$ after

the crisis $(p=0.02)$. The

association was stronger

among males. Unemployed

people were twice as likely

to report poor health.

Age-adj stress levels

increased between 2007

and $2009(P=0.004)$, only

for women $(P=0.003)$.

The OR for high stress

levels increased only

among women $(\mathrm{OR}=$

1.37), especially those

who were unemployed

$(\mathrm{OR}=3.38)$, students

$(\mathrm{OR}=2.01)$, with middle

levels of education

$(\mathrm{OR}=1.65)$, or in the

middle income bracket

$(\mathrm{OR}=1.59)$.

The odds of major

depression were greate

in 2011 than in 2008

$(\mathrm{OR}=2.6,95 \% \mathrm{Cl}=$

1.97-3.43).Financial

strain independently

and significantly predicts

the presence of major

depression $(\mathrm{OR}=1.2$
$95 \% \mathrm{Cl}=1.13-1.24)$.

\begin{tabular}{|c|c|}
\hline $\begin{array}{l}\text { udy is } \\
\text { osed of } \\
\text { arable surveys } \\
\text { multiple time } \\
\text { before and } \\
\text { he economic } \\
\text { ion period, } \\
\text { ng reports of } \\
\text { sed poor } \\
\text { across all } \\
\text { conomic }\end{array}$ & $\begin{array}{l}\text { Its cross-sectional } \\
\text { design removes the } \\
\text { possibility of causal } \\
\text { inference.The study } \\
\text { lacks individual-level } \\
\text { information on job } \\
\text { insecurity, work overload, } \\
\text { or pay cuts that can } \\
\text { work as confounders. } \\
\text { The outcome was self- } \\
\text { reported. }\end{array}$ \\
\hline
\end{tabular}

statuses.

This study examines The impact of economic

the longitudinal recessions varies across

interrelations between cultures and time

employment status and periods; thus, the

socio-demographic in generalisability of the

psychological stress findings may be

levels during a period reasonably limited by

of extensive macroeco- the uniqueness of

nomic changes.

Icelandic culture as

well as the nature as

well as the nature of

collapse in Iceland.

The study is composed Its cross-sectional

of comparable surveys design removes the

across two time points possibility of causal

before and after the inference.Limited

period of the

period of time; the

economic recession. long-term effects of

the recession could

not be investigated

Telephone survey. 
Table 2 Characteristics of studies included in the review comparing the data to pre-recession periods and mental health outcomes, 2004-2014 (Continued)

\begin{tabular}{|c|c|c|c|c|c|c|c|c|}
\hline [38] & $\begin{array}{l}\text { National population } \\
\text { sample, Greece }\end{array}$ & $\begin{array}{l}\text { Repeated } \\
\text { cross-sectional }\end{array}$ & $\begin{array}{l}2197 \\
(2008) \\
2192 \\
(2009) \\
18-69 y\end{array}$ & $\begin{array}{l}\text { Inter-time Variables } \\
\text { Psychosocial/economic } \\
\text { indicators } \\
\text { Pre- and post- recession } \\
\text { period } \\
\text { Financial strain }\end{array}$ & $\begin{array}{l}\text { Common } \\
\text { Mental } \\
\text { Disorders } \\
\text { Major depressive } \\
\text { episode-MDE } \\
\text { (SCID-I) }\end{array}$ & $\begin{array}{l}\text { The one-month prevalence } \\
\text { of MDE in } 2009 \text { was found } \\
\text { to be } 6.8 \% \text {, compared to } \\
\text { rates of } 3.3 \% \text { in } 2008 \\
(p<0.0001) \text {. Respondents } \\
\text { facing serious economic } \\
\text { hardship were at higher } \\
\text { risk of developing an MDE. }\end{array}$ & $\begin{array}{l}\text { Representative samples } \\
\text { and comparable } \\
\text { surveys across two } \\
\text { time points before and } \\
\text { during the period of } \\
\text { the economic } \\
\text { recession in Greece. }\end{array}$ & $\begin{array}{l}\text { No causal inference } \\
\text { can be made because } \\
\text { of the cross-sectional } \\
\text { nature of the study. } \\
\text { The generalisability } \\
\text { of the findings is } \\
\text { limited by the } \\
\text { uniqueness of the } \\
2008 \text { economic } \\
\text { collapse in Greece. } \\
\text { Limited period of time; } \\
\text { the long-term effects } \\
\text { of the recession could } \\
\text { not be investigated. }\end{array}$ \\
\hline [39] & $\begin{array}{l}\text { National population } \\
\text { sample, patients } \\
\text { attending primary } \\
\text { care centres, Spain }\end{array}$ & $\begin{array}{l}\text { Repeated } \\
\text { cross-sectional }\end{array}$ & $\begin{array}{l}7640 \\
(2006-07) \\
5876 \\
(2010-11)\end{array}$ & $\begin{array}{l}\text { Inter-time Variables } \\
\text { Psychosocial/economic } \\
\text { indicators } \\
\text { Pre- and post-recession } \\
\text { period } \\
\text { Employment status, } \\
\text { Mortgage payments }\end{array}$ & $\begin{array}{l}\text { Common } \\
\text { Mental } \\
\text { Disorders } \\
\text { Substance } \\
\text { Disorders } \\
\text { Depression } \\
\text { Anxiety } \\
\text { Somatoform } \\
\text { Alcohol-related } \\
\text { disorders }\end{array}$ & $\begin{array}{l}\text { Since the pre-crisis period } \\
\text { (2006), major depression } \\
\text { increased by } 19.4 \% \text {, anxiety } \\
\text { by } 8.4 \% \text {, somatoform } \\
\text { disorders by } 7.3 \% \text {, and } \\
\text { alcohol-related disorders } \\
\text { by } 4.6 \% \text {. The risk of } \\
\text { depression when } \\
\text { unemployed was } \mathrm{OR}=2.12 \text {, } \\
p<0.001 \text {. The risk of } \\
\text { depression resulting from } \\
\text { mortgage payment } \\
\text { difficulties was OR }=2.95 \text {, } \\
p<0.001 \text {. }\end{array}$ & $\begin{array}{l}\text { The study is composed } \\
\text { of comparable surveys } \\
\text { across multiple time } \\
\text { points before and after } \\
\text { the economic } \\
\text { recession period. }\end{array}$ & $\begin{array}{l}\text { Its cross-sectional } \\
\text { design removes the } \\
\text { possibility of causal } \\
\text { inference. Limited } \\
\text { period of time; the } \\
\text { long-term effects of } \\
\text { the recession could } \\
\text { not be investigated. } \\
\text { Only patients attending } \\
\text { and able to access } \\
\text { primary care were } \\
\text { investigated. }\end{array}$ \\
\hline [40] & $\begin{array}{l}\text { Regional working } \\
\text { population sample, } \\
\text { Alberta, Canada }\end{array}$ & $\begin{array}{l}\text { Repeated } \\
\text { cross-sectional }\end{array}$ & $\begin{array}{l}3579 \\
(2008-2009)\end{array}$ & $\begin{array}{l}\text { Inter-time Variables } \\
\text { Psychosocial/economic } \\
\text { indicators } \\
\text { Pre- and post-recession } \\
\text { period }\end{array}$ & $\begin{array}{l}\text { Common } \\
\text { Mental } \\
\text { Disorders } \\
\text { Major depressive } \\
\text { disorder (MDD) } \\
\text { Dysthymia } \\
\text { Anxiety (CIDI) }\end{array}$ & $\begin{array}{l}\text { The 12-month prevalence } \\
\text { of major depressive } \\
\text { disorder (MDD) before } \\
\text { September 1, 2008; } \\
\text { between September 1, } \\
\text { 2008, and March 1, 2009; } \\
\text { and between March 1, } \\
2009 \text {, and October 30, } \\
2009 \text {, was } 5.1,6.8 \text {, and } \\
7.6 \% \text { ( } P=0.03) \text {, respectively. } \\
\text { The lifetime prevalence of } \\
\text { dysthymia reported during } \\
\text { the } 3 \text { periods was } 0.4,0.7 \text {, } \\
\text { and } 1.5 \% \text { ( } P=0.006) \text {, re } \\
\text { spectively. No changes in } \\
\text { the } 12 \text {-month prevalence } \\
\text { of social phobia, panic } \\
\text { disorder, and generalized } \\
\text { anxiety disorder were } \\
\text { found over time. }\end{array}$ & $\begin{array}{l}\text { This study examines } \\
\text { changes in the } \\
\text { population } \\
\text { prevalence of } \\
\text { common mental } \\
\text { disorders before and } \\
\text { during the period of } \\
\text { the economic } \\
\text { recession. }\end{array}$ & $\begin{array}{l}\text { No causal inference } \\
\text { can be made because } \\
\text { of the cross-sectional } \\
\text { nature of the study. } \\
\text { The effects of } \\
\text { socioeconomic variables } \\
\text { were not adjusted.The } \\
\text { long-term effects of the } \\
\text { recession could not } \\
\text { be investigated. }\end{array}$ \\
\hline
\end{tabular}


Table 2 Characteristics of studies included in the review comparing the data to pre-recession periods and mental health outcomes, 2004-2014 (Continued)

[41] National population

sample, Hong Kon

China

$\begin{array}{ll}\text { Repeated } & 3016 \\ \text { cross-sectional } & (2007) \\ & 2011 \\ & (2009) \\ & 15-65 \text { y }\end{array}$

Inter-time Variables

Psychosocial/economic

Common

indicators

Pre- and post-economic

crisis period

Socioeconomic/Employment

Status

[42] National population Cohort sample, USA

2,050,431 Inter-time Variables

(2006-2007; Psychosocial/economic

2008-2009) indicators

$>18$ y Pre- and post-recession

period

Employment status

[43] Community sample, Crossprovince and city of sectional Buenos Aires, Argentina

1000 (2002) Inter-time Variables

18-65 y During recession period

Major depressive

episode (MDE)
Substance-

Disorders

Alcohol use

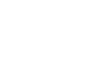

The 12-month prevalence
of MDE was significantly
higher in $2009(/ 12.5 \%)$
than $2007(8.5 \%)$. The
prevalence of MDE in the
unemployed group
increased from 2007
(14.6\%) to 2009 (17.8\%).

The prevalence of any alcohol use significantly declined from $52.0 \%$ in 2006-2007 to $51.6 \%$ in 2008-2009. There was

an increase in the

prevalence of frequent

bingeing, from $4.8 \%$

in 2006-2007 to $5.1 \%$

in 2006-2007 to $5.1 \%$

in 2008-2009 $(P<0.01)$

Unmarried non-Black
men under 30 years who

recently became unemployed

were at the greatest risk of

frequent bingeing.

Substance-Disorders During the economic crisis Patterns of drinking behaviour

Drinking-related

problems
(Genacis) people drank more at home

or at friends' homes. A large

number of respondents also

reported that people had

changed to cheaper or

lower-quality alcoholic drinks.

The study is
composed of
comparable surveys
across two time
points before and
after the period of
the economic
recession.

recession.

Because of population characteristics and cultural norms

concerning response

to economic adversity,

the findings may not

generalise to other

societies.lts cross-

sectional design

removes the possibility

of causal inference.

The long-term effects

of the recession could

not be investigated.

Large representative The generalisability

sample.Longitudinal of the findings may

measures on changes be reasonably limited

of alcohol use

to the country's own

prevalence during a policy regarding

period of economic

alcohol use and the

recession.

social welfare system.

Limited period of time;

the long-term effects

of the recession could

not be investigated.

\section{Brings evidence on} how the economic crisis is possibly

No causal inference can be made because of the cross-sectional resulting in increased design. The validity of drinking of cheaper self-reports of sensitive or lower-quality alcoholic drinks. 
Table 2 Characteristics of studies included in the review comparing the data to pre-recession periods and mental health outcomes, 2004-2014 (Continued)

\begin{tabular}{|c|c|c|c|c|c|c|c|c|}
\hline [44] & $\begin{array}{l}\text { National population } \\
\text { sample, Sweden }\end{array}$ & Cohort & $\begin{array}{l}4,224,210 \\
(1992-1996)\end{array}$ & $\begin{array}{l}\text { Inter-time Variables } \\
\text { Psychosocial/economic } \\
\text { indicators } \\
\text { Pre- and post-recession } \\
\text { period } \\
\text { Employment status }\end{array}$ & $\begin{array}{l}\text { Suicidal Behaviours } \\
\text { Excess mortality effects } \\
\text { (suicide) }\end{array}$ & $\begin{array}{l}\text { During the recession there } \\
\text { was no additional risk of } \\
\text { mortality as a result of suicide. } \\
\text { During the post-recession } \\
\text { period, there was an additional } \\
\text { risk of mortality through suicide } \\
\text { for unemployed men ( } \mathrm{HR}=1.43 \text {; } \\
95 \% \mathrm{Cl}=1.31,1.56 \text { ) but not } \\
\text { unemployed women. }\end{array}$ & $\begin{array}{l}\text { This study examines } \\
\text { longitudinal changes } \\
\text { in suicide mortality } \\
\text { during a period of } \\
\text { mass unemployment } \\
\text { in Sweden.Reports } \\
\text { post-recessionary in- } \\
\text { creases on suicide } \\
\text { among unemployed } \\
\text { men, considering } \\
\text { possible time-lagged } \\
\text { effects. }\end{array}$ & $\begin{array}{l}\text { This research study } \\
\text { fails to determine if } \\
\text { mental health declined } \\
\text { as a result of } \\
\text { unemployment, or } \\
\text { loss of benefits or } \\
\text { income over time. } \\
\text { The generalisability } \\
\text { of the findings may } \\
\text { be limited by the } \\
\text { uniqueness of the } \\
\text { Swedish welfare } \\
\text { system and its } \\
\text { economic recession. }\end{array}$ \\
\hline [45] & $\begin{array}{l}\text { National population } \\
\text { sample, Greece }\end{array}$ & $\begin{array}{l}\text { Repeated } \\
\text { cross-sectional }\end{array}$ & $\begin{array}{l}2192(2009) \\
2256(2011)\end{array}$ & $\begin{array}{l}\text { Inter-time Variables } \\
\text { Psychosocial/economic } \\
\text { indicators } \\
\text { Pre- and post-recession } \\
\text { period } \\
\text { Financial strain (Index } \\
\text { of Personal Economic } \\
\text { Distress) }\end{array}$ & $\begin{array}{l}\text { Suicidal Behaviours } \\
\text { Suicidal ideation } \\
\text { Suicide attempts }\end{array}$ & $\begin{array}{l}\text { The rate of suicidal ideation } \\
\text { increased from } 5.2 \% \text { in } \\
2009 \text { to } 6.7 \% \text { in } 2011 \\
\left(x^{2}=3.92, \mathrm{df}=1, p=0.04\right) \text {. } \\
\text { The increase was significant } \\
\text { in men }\left(7.1 \text { vs. } 4.4 \%, x^{2}=\right. \\
6.41, \mathrm{df}=1, p=0.011) \text { and } \\
\text { those aged } 55-64 \text { years } \\
\left(7.2 \text { vs. } 1.9 \%, x^{2}=14.41 \text {, }\right. \\
\mathrm{df}=1, p<0.001) \text {, while it } \\
\text { decreased in those younger } \\
\text { than } 24 \text { years }(4.9 \text { vs. } 13.9 \% \text {, } \\
\left.x^{2}=15.83, \mathrm{df}=1, p<0.001\right) . \\
\text { Suicidal ideation increased } \\
\text { among psychotropic medication } \\
\text { users }\left(22.7 \text { vs. } 4.5 \%, x^{2}=11.10,\right. \\
\mathrm{df}=1, p<0.001) \text { and those } \\
\text { asking for mental healthcare } \\
\left(17.3 \text { vs. } 8.3 \%, x^{2}=13.36, \mathrm{df}=1 \text {, }\right. \\
p<0.001) . \text { No unemployed } \\
\text { respondent reported a suicide } \\
\text { attempt in } 2009, \text { while the } \\
\text { proportion was } 4.4 \% \text { in } 2011 \\
\left(x^{2}=4.12 . \mathrm{df}=1, p=0.042\right) \text {. }\end{array}$ & $\begin{array}{l}\text { Representative } \\
\text { sample.This study } \\
\text { provides evidence on } \\
\text { the increase in the } \\
\text { prevalence of suicidal } \\
\text { ideation and reported } \\
\text { suicide attempts in a } \\
\text { country facing a deep } \\
\text { economic recession. }\end{array}$ & $\begin{array}{l}\text { Reported suicidal } \\
\text { ideation and suicide } \\
\text { attempts can be } \\
\text { susceptible to recall } \\
\text { bias or to reluctance } \\
\text { on the part of } \\
\text { respondents to } \\
\text { disclose such sensitive } \\
\text { information. No causal } \\
\text { inference can be made } \\
\text { because of the cross- } \\
\text { sectional nature of } \\
\text { the study. Limited } \\
\text { period of time; the } \\
\text { long-term effects of } \\
\text { the recession could } \\
\text { not be investigated. } \\
\text { The generalisability of } \\
\text { the findings may be } \\
\text { reasonably limited by } \\
\text { the uniqueness of the } \\
2008 \text { economic } \\
\text { collapse in Greece. }\end{array}$ \\
\hline
\end{tabular}


Table 2 Characteristics of studies included in the review comparing the data to pre-recession periods and mental health outcomes, 2004-2014 (Continued)

[46] National population

sample, South Korea

(1)

$\begin{array}{ll}\text { Repeated } & 27,745(1998) \\ \text { cross-sectional } & 27,413(2001) \\ & 25,487(2005) \\ & 3335(2007) \\ & >19 y\end{array}$

Inter-time Variables
Psychosocial/economic
indicators
Pre- and post-recession
period

Socioeconomic inequalities

[47] National Population sample, Spain

Ecological study
(2005-2010) Inter-time Variables

Pre- and post-recession

period
Mental

Disorders

Suicidal

Depression

(doctor-diagnosed)

Suicidal ideation

Suicide attempts
Suicidal Behaviours National suicide rates
The pro-rich inequalities in the prevalence of depression, suicidal ideation and suicide suicidal ideation and suicide 1998 and 2007. The Cl for depression decreased from -0.126 (SE: 0.068) in 1998 to -0.278 (SE: 0.068) in 2001 and stayed constant. The $\mathrm{Cl}$ for suicidal ideation fell gradually: -0.138 (SE: 0.012 ) in 1998 and -0.250 (SE: 0.028) in 2007. The $\mathrm{Cl}$ for suicide attempts increased from -0.22 (SE: 0.062 ) in 1998 to -0.175 (SE: 0.075) in 2001 and -0.179 (SE: 0.089) in 2005, and in 2007 to -0.400 (SE: 0.116).

An $8.0 \%$ increase was found in the suicide rate above the trend since the financial crisis (95\% Cl: 1.009-1.156; $P=0.03$ ). Stratified analyses suggested that the association between the crisis and suicide rates is greatest in males and those of working age.

uicidal Behaviours Hospital records on suicide attempts $\begin{array}{ll}\text { [48] Regional population } & \text { Ecological } \\ \text { sample, Andalusia, } & \text { study }\end{array}$ Spain
24,380

period
Compared to the historical trends prior tothe onset of the crisis, between 2008 and 2012 there were 4989 more suicide attempts $(95 \% \mathrm{Cl}$ : 1985-8013): 2017 (95 \% Cl: 87-3987) in men and 2972 women. In men, an association between unemployment and suicidal behaviour was found.

\section{Nationally}

Reported suicidal data setsThe study is attempts can be composed of comparable surveys across several time points before and after the period of

the economic

recession.

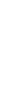

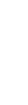

Uses stratified for seasonal

fluctuations.

on the part of

help.No causal

inference can be

made as it is a

Because of its

ecological nature,

the quality of the analyses and adjusted

susceptible to recall

bias or to reluctance

disclose such sensitive

information.Depressed

individuals in lower

income groups might

have been under-

represented because

of financial difficulties

in seeking professional

cross-sectional study.

data is not assessable

and no implications

can be drawn

regarding causality.

The results should

be interpreted with

caution as other

variables, independent

of economic conditions,

may be involved in

the precipitation of

suicide.

First ad hoc study of Because of its ecological the impact of the recession on suicide attempts in Spain based on hospita records in a large population sample. nature, the quality of the data is not assessable and no implications can be drawn regarding causality. The results should be interpreted with caution as other variables, independent of economic conditions, may be involved in the
precipitation of suicide. 
Table 2 Characteristics of studies included in the review comparing the data to pre-recession periods and mental health outcomes, 2004-2014 (Continued)

[49] Regional population sample, Andalusia Spain study $1975-2012$

\section{nter-time Variables}

Pre- and post-recession period study $(1980-20$ er-time Variables sample, Italy $>15$ y Pre- and post-recession period

Ecological
study

2008-2010 sample, England, UK
Inter-time Variables

Macroeconomic

indicators

Pre- and post-recession

period

Regional unemployment

rate

Suicidal Behaviours
Regional suicide rates
Sucide rates have increased an upward trend has been observed in young people (15 to $44 \mathrm{y}$ ), an annual percentage rate change of 1.21 (95\%Cl: 0.7-1.7) for men and 0.93 (95\% Cl: 0.4-1.4) for women.

Suicidal Behaviours National suicide rates

Regional trend analysis of the variation in suicide rates.

Because of its ecologica Because of its ecologica data is not assessable and no implications and no implications can be drawn regarding causality. The results should be interpreted with caution as other variables, independent of economic conditions, may be involved in the precipitation of suicide.

The suicide rate for men involved in the labour force increased by $12 \%$ in 2010 compared with that in 2006. The suicide rate declined for women of all ages and for men younger than 25 and older than 65 years of age.

Examined trends in

the total official ecological nature, the

Because of its suicide rate before quality of the data is

and after the onset of not assessable and no

the recession. implications can be

drawn regarding

causality. The results

should be interpreted

with caution as other

of economic conditions,

may be involved in

the precipitation of

suicide. There were

no economic variables

involved in the analyses.

Examined trends in

Because of its

Suicidal Behaviours During 2008 and 2010,

National suicide rates

there were 846 more

(95 \% Cl: 818-877)

suicides among men

and 155 (121-189)

more suicides among

women than would

have been expected

on the basis of historical

trends. The $10 \%$ increase

in men's unemployment

was significantly associated

with an increase of $1.4 \%$

$(0.5-2.3 \%)$ in suicides. before and after the quality of the data is onset of the recession not assessable and no

and in relation to

unemployment rates.

drawn regarding

causality. The results should be interpreted with caution as other variables, independent of economic conditions, may be involved in the precipitation of suicide. the total suicide rate ecological nature, the 
Table 2 Characteristics of studies included in the review comparing the data to pre-recession periods and mental health outcomes, 2004-2014 (Continued)

\begin{tabular}{|c|c|c|c|c|c|c|c|c|}
\hline [52] & $\begin{array}{l}\text { National population } \\
\text { sample, England and } \\
\text { Wales, UK }\end{array}$ & $\begin{array}{l}\text { Ecological } \\
\text { study }\end{array}$ & $\begin{array}{l}(2001-2011) \\
16-64 y\end{array}$ & $\begin{array}{l}\text { Inter-time Variables } \\
\text { Pre- and post-recession } \\
\text { period }\end{array}$ & $\begin{array}{l}\text { Suicidal Behaviours } \\
\text { National Suicide Rates }\end{array}$ & $\begin{array}{l}\text { The downward trend in } \\
\text { the suicide rate for men } \\
\text { stopped for men aged } \\
\text { 16-34 years in } 2006 \\
\text { (95\% Cl Quarter } 3 \text { (Q3) } \\
2004 \text {, Q3 } 2007 \text { for 16- } \\
24-\text { year-olds \& Q1 2005, } \\
\text { Q4 2006 for 25-34-year-olds). } \\
\text { The suicide rate in 35- } \\
\text { 44-year-old men reversed } \\
\text { from a downward to an } \\
\text { upward trend in early } 2010 \\
\text { (95\% CI Q4 2008, Q2 2011). } \\
\text { No clear evidence of an } \\
\text { association between trends } \\
\text { in female suicide rates and } \\
\text { indicators of economic } \\
\text { recession was found. }\end{array}$ & $\begin{array}{l}\text { Used age- and sex- } \\
\text { specific trends in sui- } \\
\text { cide in the years be- } \\
\text { fore and after the } \\
\text { economic recession } \\
\text { of } 2008 \text { in relation to } \\
\text { a variety of indicators } \\
\text { of recession effects. } \\
\text { Excluded accidental } \\
\text { deaths }\end{array}$ & $\begin{array}{l}\text { Because of its ecological } \\
\text { nature, the quality of } \\
\text { the data is not assessable } \\
\text { and no implications can } \\
\text { be drawn regarding } \\
\text { causality. The results } \\
\text { should be interpreted } \\
\text { with caution as other } \\
\text { variables, independent } \\
\text { of economic conditions, } \\
\text { may be involved in the } \\
\text { precipitation of suicide. }\end{array}$ \\
\hline [53] & $\begin{array}{l}\text { Cross-national } \\
\text { population samples, } \\
\text { EU, Canada and USA }\end{array}$ & $\begin{array}{l}\text { Ecological } \\
\text { study }\end{array}$ & $2001-2011$ & $\begin{array}{l}\text { Inter-time Variables } \\
\text { Pre- and post-recession } \\
\text { period }\end{array}$ & $\begin{array}{l}\text { Suicidal Behaviours } \\
\text { National suicide rates }\end{array}$ & $\begin{array}{l}\text { In the EU, there was a rise } \\
\text { in the suicide rate of } 6.5 \% \\
\text { above past trends in } 2009 \text {. } \\
\text { In Canada, suicides rose } \\
\text { by } 4.5 \% \text { between } 2007 \\
\text { and } 2009 \text {. In the USA, } \\
\text { suicides rose by } 4.8 \% \\
\text { between } 2007 \text { and } 2010 \text {. }\end{array}$ & $\begin{array}{l}\text { Cross-national } \\
\text { analysis. Examined } \\
\text { trends in the total } \\
\text { official suicide rate } \\
\text { before and after the } \\
\text { onset of the } \\
\text { recession. }\end{array}$ & $\begin{array}{l}\text { Because of its ecological } \\
\text { nature, the quality of } \\
\text { the data is not assessable } \\
\text { and no implications can } \\
\text { be drawn regarding } \\
\text { causality. The results } \\
\text { should be interpreted } \\
\text { with caution as other } \\
\text { variables, independent } \\
\text { of economic conditions, } \\
\text { may be involved in the } \\
\text { precipitation of suicide. } \\
\text { Suicide rates may vary } \\
\text { across nations for } \\
\text { cultural reasons. }\end{array}$ \\
\hline [54] & $\begin{array}{l}\text { National population } \\
\text { sample, USA }\end{array}$ & $\begin{array}{l}\text { Ecological } \\
\text { study }\end{array}$ & 1999-2010 & $\begin{array}{l}\text { Inter-time Variables } \\
\text { Macroeconomic } \\
\text { indicators } \\
\text { Pre- and post-recession } \\
\text { period } \\
\text { State-level unemployment } \\
\text { rate }\end{array}$ & $\begin{array}{l}\text { Suicidal Behaviours } \\
\text { National suicide rate }\end{array}$ & $\begin{array}{l}\text { The suicide rate accelerated } \\
\text { after the onset of the recession. } \\
\text { There were an additional } 0.51 \\
\text { deaths per } 100,000 \text { per year } \\
(95 \% \mathrm{Cl} 0 \cdot 28-0 \cdot 75) \text { in } 2008- \\
10 \text { - an additional } 1580 \\
\text { suicides per year }(95 \% \mathrm{Cl} \\
860-2300) \text {. A } 1 \% \text { rise in } \\
\text { unemployment is associated } \\
\text { with a } 0.99 \% \text { increase in } \\
\text { the suicide rate } \\
(95 \% \mathrm{Cl} 0 \cdot 60-1 \cdot 38 \text {, } \\
p<0 \cdot 0001)\end{array}$ & $\begin{array}{l}\text { Examined trends in } \\
\text { the total suicide rate } \\
\text { before and after the } \\
\text { onset of the recession } \\
\text { and in relation to } \\
\text { unemployment rates. }\end{array}$ & $\begin{array}{l}\text { Because of its ecological } \\
\text { nature, the quality of } \\
\text { the data is not assessable } \\
\text { and no implications can } \\
\text { be drawn regarding } \\
\text { causality. The results } \\
\text { should be interpreted } \\
\text { with caution as other } \\
\text { variables, independent } \\
\text { of economic conditions, } \\
\text { may be involved in the } \\
\text { precipitation of suicide. }\end{array}$ \\
\hline
\end{tabular}


prevalence of anxiety disorders [39]. Nevertheless, no changes in the prevalence of anxiety were found in the Canadian working population sample [40].

\section{Pre and post-economic recession changes in substance- related disorders}

A cohort study from the USA stated that the overall prevalence of any alcohol use significantly declined during the recession but, conversely, binge-drinking became more frequent [42]. Spanish repeated cross-sectional evidence shows that this recession may have triggered alcoholrelated disorders, since a noteworthy rise of $4.6 \%$ in the abuse of alcohol and dependence on it was observed [39]. Furthermore, available data from Argentina also revealed that people may tend to increase their intake of lowerquality alcohol, which is known to pose additional threats to health [43].

\section{Pre and post-economic recession changes in suicidal behaviours}

Longitudinal evidence during the Swedish recession reported a post-recessionary increase in suicide rates among unemployed men [44] suggesting possible delayed effects of the recession on suicidal behaviours. Similarly, Greek cross-sectional data, from before and after the onset of the recession, indicated that the rate of suicidal ideation increased significantly in men [45]. Moreover, in South Korea data from comparable surveys also showed that income gradient-related suicide behaviour was found to have increased in the years after the recession period [46].

Several ecological studies from Spain have reported a substantial growth of suicidal ideation and suicide attempts [47-49]. In Italy, an ecological study showed an evident increase in suicide rates among Italian men involved in the labour force after 2007 [50]. Similar evidence comes from the UK, where time-trends analysis displayed an increase in the suicide rate, especially among working-age men [51, 52]. In an ecological analysis, Reeves et al. found that most of the European countries experienced a significant rise $(6.5 \%)$ in suicide rates after the onset of the recession in 2009 [53]. The same was found in Canada (a rise of $4.5 \%$ ) and in the USA (a rise of $4.8 \%)$ [54].

\section{Macroeconomic indicators associated with mental health outcomes}

Data from cohort studies focusing on unemployment rates (Table 3) have shown that high unemployment rates are linked to individuals' worsened mental wellbeing and higher mental distress levels [55-57]. Similar evidence was found in a cross-sectional study from the USA $[58,59]$.
A large cross-national ecological study has shown that rises in unemployment among the population are also associated with lower life satisfaction levels, especially among unemployed individuals [58]. Despite this evidence, however, there is a recent ecological study from Spain that suggests that rises in unemployment rates were associated with a decrease in the demand for mental healthcare [60].

Recent ecological studies provide evidence of a strong positive association between unemployment rates and suicidal behaviour. A study that covered 30 countries (European, North American, and Australia) demonstrates that increases in the unemployment rate related to the recession period have a negative impact on suicide, especially in those Eastern and Southern European countries with the least developed social protection systems [61]. Similar evidence has been found in studies focusing solely on European countries [62-66] and studies performed in the USA [67-69], as well as in South Korea [70]. In Greece two studies also found strong correlations between unemployment rates and suicide [71, 72], though there is one study reporting no correlation and no increase in suicide behaviours [73]. In England, these correlations were only statistically significant at the regional level [74], and in Hungary the correlations were only strong 3 to 5 years after the onset of the recession [75]. Using other macroeconomic indicators, Houle et al. found that the state-level foreclosure rate also correlated to suicide rates in the USA [76] and an Italian study found that the decrease in GDP per person was associated with male suicide [77].

\section{Individual-level indicators associated with mental health outcomes \\ Unemployment}

Studies demonstrate that people who lose their job during a recession are more vulnerable to the economic recession. For instance, during the Japanese economic crisis unemployed people were twice as likely to report poor health compared to controls [35]. In Hong Kong the prevalence of a major depression episode increased among the unemployed [41]. In addition, research dealing with the European recession shows a significantly higher risk of depression and mental distress among this group of people compared to the general population $[28,29,33,39]$, although Icelandic and Swedish data showed increased stress levels only for unemployed women $[34,36]$. When variations in macroeconomic indicators are considered, the unemployed were also more vulnerable to mental health problems and suicidal behaviour $[56,57,70]$.

Several individual-level cohort studies (Table 4) found an association between job loss and poor mental health 
Table 3 Characteristics of studies included in review relating macroeconomic indicators and mental health outcomes, 2004-2014

\begin{tabular}{|c|c|c|c|c|c|c|c|c|}
\hline Study & Setting & $\begin{array}{l}\text { Study } \\
\text { design }\end{array}$ & $\begin{array}{l}\mathrm{N} \\
\text { Year } \\
\text { Age }\end{array}$ & $\begin{array}{l}\text { Socioeconomic } \\
\text { determinants }\end{array}$ & $\begin{array}{l}\text { Mental health } \\
\text { outcomes }\end{array}$ & Associations/Effects & Strengths & Limitations \\
\hline [55] & $\begin{array}{l}\text { National population } \\
\text { sample, USA }\end{array}$ & Cohort & $\begin{array}{l}26,313 \\
18-59 y\end{array}$ & $\begin{array}{l}\text { Macroeconomic } \\
\text { indicators } \\
\text { State level } \\
\text { unemployment rate }\end{array}$ & $\begin{array}{l}\text { Psychological } \\
\text { Well-being } \\
\text { Health Related } \\
\text { Quality of Life, } \\
\text { Mental Health } \\
\text { Component } \\
\text { Summary } \\
\text { Scale - (SF-12 } \\
\text { Health Survey) }\end{array}$ & $\begin{array}{l}\text { Increases in average state } \\
\text { unemployment rate worsen } \\
\text { individual's HRQL. During } \\
\text { hard economic times } \\
\text { mental health decreases } \\
\text { more than physical health }\end{array}$ & $\begin{array}{l}\text { Temporal order of } \\
\text { exposures under } \\
\text { consideration affected } \\
\text { all participants at the } \\
\text { same time producing } \\
\text { stronger causal } \\
\text { conclusions. }\end{array}$ & $\begin{array}{l}\text { The effect sizes are relatively } \\
\text { small in magnitude.The results } \\
\text { and recommendations should } \\
\text { not be generalized to } \\
\text { other cohorts. }\end{array}$ \\
\hline$[56]$ & $\begin{array}{l}\text { National population } \\
\text { sample, Britain, UK }\end{array}$ & Cohort & $\begin{array}{l}10,264 \\
(1991-2008) \\
16-65 y\end{array}$ & $\begin{array}{l}\text { Macroeconomic } \\
\text { indicators } \\
\text { Local area } \\
\text { unemployment rate }\end{array}$ & $\begin{array}{l}\text { Psychological } \\
\text { Well-being } \\
\text { Mental health } \\
\text { distress (GHQ-12) }\end{array}$ & $\begin{array}{l}\text { Mental distress levels } \\
\text { among unemployed } \\
\text { people are significantly } \\
\text { higher than among their } \\
\text { securely employed } \\
\text { counterparts (2.20; } 95 \% \\
\text { Cl:1.98-2.42). Residence } \\
\text { in a high-unemployment } \\
\text { area protects against } \\
\text { distress if unemployed. }\end{array}$ & $\begin{array}{l}\text { Annual data collected } \\
\text { over a } 17 \text { year period. } \\
\text { Temporal order of } \\
\text { exposures, confounders, } \\
\text { and the outcome under } \\
\text { consideration affected } \\
\text { all participants at the } \\
\text { same time producing } \\
\text { stronger causal } \\
\text { conclusions. }\end{array}$ & $\begin{array}{l}\text { Possible bias due to selection } \\
\text { effects threat causal inference } \\
\text { since those with poor mental } \\
\text { health are more likely to } \\
\text { subsequently become } \\
\text { unemployed. }\end{array}$ \\
\hline$[57]$ & $\begin{array}{l}\text { National } \\
\text { unemployed } \\
\text { population sample, } \\
\text { Sweden }\end{array}$ & Cohort & $\begin{array}{l}1806 \\
(1996) \\
1415 \\
(1997) \\
19-64 y\end{array}$ & $\begin{array}{l}\text { Macroeconomic } \\
\text { indicators } \\
\text { Regional } \\
\text { unemployment } \\
\text { and vacancy rate }\end{array}$ & $\begin{array}{l}\text { Psychological } \\
\text { Well-being } \\
\text { Mental health } \\
\text { distress (GHQ-12) }\end{array}$ & $\begin{array}{l}\text { Significant negative effects } \\
\text { of both unemployment } \\
\text { rate }(-0.22) \text { and vacancy } \\
\text { rate }(-5.29) \text { on the level } \\
\text { of mental health among } \\
\text { the unemployed. }\end{array}$ & $\begin{array}{l}\text { Dataset surveyed in two } \\
\text { times and shows that } \\
\text { higher municipal } \\
\text { vacancy rates improved } \\
\text { mental health among } \\
\text { the unemployed }\end{array}$ & $\begin{array}{l}\text { The cross-sectional result of } \\
\text { vacancy rates by longitudinal } \\
\text { analysis of change gives some } \\
\text { information on this being } \\
\text { an effect of ecological } \\
\text { modification and not } \\
\text { differential health-based } \\
\text { selection. }\end{array}$ \\
\hline [59] & $\begin{array}{l}\text { National population } \\
\text { sample of working- } \\
\text { age men, USA }\end{array}$ & $\begin{array}{l}\text { Repeated } \\
\text { cross- } \\
\text { sectional }\end{array}$ & $\begin{array}{l}30,000 \\
(1997) \\
35,000 \\
(2001)\end{array}$ & $\begin{array}{l}\text { Macroeconomic } \\
\text { indicators } \\
\text { Local area } \\
\text { unemployment rate }\end{array}$ & $\begin{array}{l}\text { Psychological } \\
\text { Well-being } \\
\text { Mental health } \\
\text { distress caseness } \\
\text { (K6) }\end{array}$ & $\begin{array}{l}1 \text { percentage point increase } \\
\text { in the local unemployment } \\
\text { rate leads to } 3.4,3.3,2.5,3.5, \\
3.5 \text { and } 3.8 \text { percentage point } \\
\text { increases in responding } \\
\text { affirmatively to sadness, } \\
\text { hopelessness, worthlessness, } \\
\text { restlessness, nervousness, and } \\
\text { feelings of effort, respectively. }\end{array}$ & $\begin{array}{l}\text { Gives systematic } \\
\text { evidence of the } \\
\text { procyclical nature of } \\
\text { mental health, in } \\
\text { several clusters. }\end{array}$ & $\begin{array}{l}\text { Does not take into account } \\
\text { the lagged effect of } \\
\text { macroeconomic conditions } \\
\text { on mental health.ts cross- } \\
\text { sectional design removes the } \\
\text { possibility of causal inference. }\end{array}$ \\
\hline [58] & $\begin{array}{l}\text { Cross-national,40 } \\
\text { European and } \\
\text { Anglo-Saxon } \\
\text { societies }\end{array}$ & $\begin{array}{l}\text { Ecological } \\
\text { study }\end{array}$ & $\begin{array}{l}42,275 \\
(2000-2004) \\
(2005-2007)\end{array}$ & $\begin{array}{l}\text { Macroeconomic } \\
\text { indicators } \\
\text { Employment } \\
\text { status, GDP, } \\
\text { income inequality }\end{array}$ & $\begin{array}{l}\text { Psychological } \\
\text { Well-being } \\
\text { Life satisfaction }\end{array}$ & $\begin{array}{l}\text { Unemployment lowers } \\
\text { substantially the level of } \\
\text { life-satisfaction (-0.761 } \\
\text { to }-0.785 \text { points lower than } \\
\text { those employed). GDP per } \\
\text { capita and income inequality }\end{array}$ & $\begin{array}{l}\text { Large cross-national sam- } \\
\text { ple with attention to the } \\
\text { macroeconomic variables } \\
\text { of countries. }\end{array}$ & $\begin{array}{l}\text { Not all contexts that affect } \\
\text { the relationship between } \\
\text { unemployment and life- } \\
\text { satisfaction may be placed } \\
\text { at the national level. }\end{array}$ \\
\hline
\end{tabular}


Table 3 Characteristics of studies included in review relating macroeconomic indicators and mental health outcomes, 2004-2014 (Continued)

[60] Regionalpopulation sample, Asturias, Spain

study

2000-2010

Macroeconomic

indicators

National

unemployment

Psychologic

Well-being

hospital records

rate, GDP

and prevalence

of mental illness

[61] Cross-national

samples of 30

countries EU, North

American and

Australia
Found a negative correlation of unemployment rate with mental health care demand. Unemployment rate was associated with a decrease in both new and prevalen mental health demand.

Unemployment rate increase has a detrimental impact on suicide, especially in country groups with the least developed unemployment protection (eastern and southern Europe).

A $1 \%$ increase in unemployment rates, suicide rates increase by 0.09 . Male suicides increase by 0.21 (per 100,000 male inhabitants). The relationship is positive for women but not statistically significant.

$\%$ increase in unemployment increases suicide at $0.79 \%$ in ages younger than 65 years $(95 \% \mathrm{Cl} 0 \cdot 16-1 \cdot 42 ; 60-550$ potential excess deaths [mean 310]).A more than $3 \%$ increase in unemployment increases suicide in $4.45 \%$ at ages

younger than 65 years $(95 \% \mathrm{C}$ $0 \cdot 65-8 \cdot 24 ; 250-3220$ potential excess deaths [mean 1740]) an $28 \%$ deaths from alcohol $(12$. 30-43 - 70; 1550-5490 potentia excess deaths [mean 3500]
Regionally analysis of The series studied ended in the association 2010, just before the inten

2010 just before the intense care demand and the of its ecological nature, the variation of the unemployment rate quality of data is no assessable and no implications on causality can be drawn. Results should be interpreted with caution.

Large cross-national sample covering a

Because of its ecological nature, the quality of data is not assessable and no implications on causality can be drawn. Results should be interpreted with caution as other variables, independent of economic conditions, may be involved in the precipitation of suicide.

Cross-national level Because of its ecological trends analysis covering nature, the quality of data is the period of recession. not assessable and no implications on causality can be drawn. Results should be interpreted with caution as other variables, independent of economic conditions, may be involved in the precipitation of suicide.

Large cross-national sample covering a period of 37 years.

It is limited to 2007. Because of its ecological nature, the quality of data is not assessable and no implications on causality can be drawn. Results should be interpreted with caution as other variables, independent of economic conditions, may be involved in the precipitation of suicide. 
Table 3 Characteristics of studies included in review relating macroeconomic indicators and mental health outcomes, $2004-2014$ (Continued)

\begin{tabular}{|c|c|c|c|c|c|c|c|c|}
\hline$[64]$ & $\begin{array}{l}\text { Cross-national } \\
\text { samples of } 23 \mathrm{EU} \\
\text { countries }\end{array}$ & $\begin{array}{l}\text { Ecological } \\
\text { study }\end{array}$ & $2000-2010$ & $\begin{array}{l}\text { Macroeconomic } \\
\text { indicators } \\
\text { National } \\
\text { unemployment rate }\end{array}$ & $\begin{array}{l}\text { Suicidal Behaviours } \\
\text { National suicide rates }\end{array}$ & $\begin{array}{l}\text { A } 1 \% \text { increase in unemployment } \\
\text { rates, suicide rates increase by } 34.1 \% \text {. }\end{array}$ & $\begin{array}{l}\text { Cross-national level } \\
\text { trends analysis covering } \\
\text { the period of recession. }\end{array}$ & $\begin{array}{l}\text { Because of its ecological } \\
\text { nature, the quality of data is } \\
\text { not assessable and no } \\
\text { implications on causality } \\
\text { can be drawn. Results } \\
\text { should be interpreted with } \\
\text { caution as other variables, } \\
\text { independent of economic } \\
\text { conditions, may be involved } \\
\text { in the precipitation of } \\
\text { suicide. The time series is } \\
\text { limited to a decade. }\end{array}$ \\
\hline$[65]$ & $\begin{array}{l}\text { Cross-national } \\
\text { samples of } 20 \mathrm{EU} \\
\text { countries }\end{array}$ & $\begin{array}{l}\text { Ecological } \\
\text { study }\end{array}$ & $1981-2011$ & $\begin{array}{l}\text { Macroeconomic } \\
\text { indicators } \\
\text { National } \\
\text { unemployment rate }\end{array}$ & $\begin{array}{l}\text { Suicidal Behaviours } \\
\text { National male suicide } \\
\text { rates }\end{array}$ & $\begin{array}{l}\text { Male suicide increases significantly } \\
0.94 \% \text { with each rise in male } \\
\text { unemployment ( } 95 \% \mathrm{Cl}: 0.51-1.36 \%)\end{array}$ & $\begin{array}{l}\text { Large cross-national } \\
\text { sample covering a } \\
\text { period of } 30 \text { years. }\end{array}$ & $\begin{array}{l}\text { Focus only in male suicide. } \\
\text { Because of its ecological } \\
\text { nature, the quality of data is } \\
\text { not assessable and no } \\
\text { implications on causality } \\
\text { can be drawn. Results } \\
\text { should be interpreted with } \\
\text { caution as other variables, } \\
\text { independent of economic } \\
\text { conditions, may be involved } \\
\text { in the precipitation of } \\
\text { suicide. }\end{array}$ \\
\hline$[66]$ & $\begin{array}{l}\text { Cross-national } \\
\text { samples of } 8 \mathrm{EU} \\
\text { countries }\end{array}$ & $\begin{array}{l}\text { Ecological } \\
\text { study }\end{array}$ & 2000-2010 & $\begin{array}{l}\text { Macroeconomic } \\
\text { indicators } \\
\text { Unemployment } \\
\text { rate and GDP }\end{array}$ & $\begin{array}{l}\text { Suicidal Behaviours } \\
\text { National suicide rates }\end{array}$ & $\begin{array}{l}\text { Rise on unemployment rates } \\
\text { and decline GDP incresed } \\
\text { suicide mortality (Germany }+5.3 \% \text {, } \\
\text { Portugal }+5.2 \% \text {, Czech Republic }+7.6 \% \text {, } \\
\text { Slovakia }+22.7 \% \text { and Poland }+19.3 \% \text { ). } \\
\text { In low social spending countries, } \\
\text { unemployment rate has a stronger } \\
\text { effect on suicide. }\end{array}$ & $\begin{array}{l}\text { Cross-national level } \\
\text { trends analysis covering } \\
\text { the period of recession. }\end{array}$ & $\begin{array}{l}\text { The time series is limited to } \\
\text { a decade. The ecological } \\
\text { design does not allow for } \\
\text { control of potential } \\
\text { confounders or effect } \\
\text { modifiers. Results should be } \\
\text { interpreted with caution as } \\
\text { other variables, independent } \\
\text { of economic conditions, } \\
\text { may be involved in the } \\
\text { precipitation of suicide. }\end{array}$ \\
\hline$[67]$ & $\begin{array}{l}\text { National Population } \\
\text { sample, USA }\end{array}$ & $\begin{array}{l}\text { Ecological } \\
\text { study }\end{array}$ & 1979-2004 & $\begin{array}{l}\text { Macroeconomic } \\
\text { indicators } \\
\text { Unemployment } \\
\text { rate and GDP }\end{array}$ & $\begin{array}{l}\text { Suicidal Behaviours } \\
\text { National suicide rates }\end{array}$ & $\begin{array}{l}\text { Higher unemployment rates } \\
\text { for prime working-age ( } 35-64) \\
\text { men and women are positively } \\
\text { correlated with their higher } \\
\text { suicide rates }\end{array}$ & $\begin{array}{l}\text { Cross-state level trends } \\
\text { analysis }\end{array}$ & $\begin{array}{l}\text { The time series is limited to } \\
\text { 2004, higher effects are } \\
\text { expected afterwards. The } \\
\text { ecological design does not } \\
\text { allow for control of } \\
\text { potential confounders or } \\
\text { effect modifiers. Results } \\
\text { should be interpreted with } \\
\text { caution as other variables, } \\
\text { independent of economic } \\
\text { conditions, may be involved } \\
\text { in the precipitation of } \\
\text { suicide. }\end{array}$ \\
\hline
\end{tabular}


Table 3 Characteristics of studies included in review relating macroeconomic indicators and mental health outcomes, $2004-2014$ (Continued)

[68] National Population Ecological 1997-2010 sample, USA
Macroeconomic

indicators

Employment Rate

Suicidal Behaviours

Strong positive association

between unemployment

rates and total suicide rates

over time. Strong explanation

among the middle-aged suicides

but cannot explain temporal

variation in suicide rates among

the young and elderly.

[69] National population Ecological 1968-2008 sample, USA

$$
\text { study }
$$

$$
\begin{gathered}
\text { indicators } \\
\text { State level }
\end{gathered}
$$

unemployment rate

[70] National population sample, South

study

cal 2003-2011

Korea

study

indicators

unemployment rate

Suicidal Behaviours

National suicide rates

Suicidal Behaviours A 1-percentage-point increase in

State level suicide rates the state unemployment rate was

associated with $0.16(95 \% \mathrm{Cl}$ :

$0.08,0.24$ ) more suicide deaths

per 100,000 population. The

presence of generous state

unemployment benefit

programs buffer the impact of

unemployment rates on suicide.

National unemployment rate

was positively and significantly

associated with the unemployed and employed suicide rate.

Examined trends in the Because of its ecological total suicide rate and in nature, the quality of data is the rate disaggregated not assessable and no by sex, age group and implications on causality time period and include can be drawn. Results a number of important should be interpreted with confounding factors in caution as other variables,

a multivariate analysis. independent of economic conditions, may be involved in the precipitation of suicide.

State fixed-effect analysis covering 1968

2008 on suicide rates

Because of its ecological

nature, the quality of data is

not assessable and no implications on causality

can be drawn. Results

should be interpreted with caution as other variables, independent of economic conditions, may be involved in the precipitation of suicide.

National level trends analysis covering the period of recession.

Because of its ecological

nature, the quality of data is

not assessable and no implications on causality can be drawn. Results should be interpreted with caution as other variables, independent of economic conditions, may be involved in the precipitation of suicide. The time series is limited to 8 years.

Suicidal Behaviours National suicide rates indicators National unemployment rate, government expenditure
Unemployment rates and suicide rates were highly correlated $(0.45)$

$1 \%$ increase in unemployment of males (25-44y), increases suicide rates in $4.5 \%$. Austerity measures and negative economic growth also significantly increase male suicide rates.
Evaluates specific Because of its ecological effects of fiscal austerity, nature, the quality of data is among other socio- not assessable and no economic variables, on implications on causality suicide rates over reces- can be drawn. Results sion period. should be interpreted with caution as other variables, independent of economic conditions, may be involved in the precipitation of suicide. 
Table 3 Characteristics of studies included in review relating macroeconomic indicators and mental health outcomes, 2004-2014 (Continued)

\begin{tabular}{|c|c|c|c|c|c|c|c|c|}
\hline [72] & $\begin{array}{l}\text { National population } \\
\text { sample, Greece }\end{array}$ & $\begin{array}{l}\text { Ecological } \\
\text { study }\end{array}$ & 1991-2011 & $\begin{array}{l}\text { Macroeconomic } \\
\text { indicators } \\
\text { Unemployment } \\
\text { rate and GDP }\end{array}$ & $\begin{array}{l}\text { Suicidal Behaviours } \\
\text { National suicide rates }\end{array}$ & $\begin{array}{l}\text { Suicide rates are positively and } \\
\text { significantly correlated with } \\
\text { percentage of public debt in } \\
\text { GDP and unemployment. }\end{array}$ & $\begin{array}{l}\text { National level trends } \\
\text { analysis covering the } \\
\text { period of recession and } \\
\text { macroeconomic } \\
\text { fluctuations }\end{array}$ & $\begin{array}{l}\text { Because of its ecological } \\
\text { nature, the quality of data is } \\
\text { not assessable and no } \\
\text { implications on causality } \\
\text { can be drawn. Results } \\
\text { should be interpreted with } \\
\text { caution as other variables, } \\
\text { independent of economic } \\
\text { conditions, may be involved } \\
\text { in the precipitation of } \\
\text { suicide. The time series is } \\
\text { limited to } 10 \text { years }\end{array}$ \\
\hline [73] & $\begin{array}{l}\text { National population } \\
\text { sample, Greece }\end{array}$ & $\begin{array}{l}\text { Ecological } \\
\text { study }\end{array}$ & 2000-2010 & $\begin{array}{l}\text { Macroeconomic } \\
\text { indicators } \\
\text { National } \\
\text { unemployment rate, } \\
\text { growth rate }\end{array}$ & $\begin{array}{l}\text { Suicidal Behaviours } \\
\text { National suicide rates }\end{array}$ & $\begin{array}{l}\text { The correlations between suicidal rates } \\
\text { and unemployment and growth rate } \\
\text { were about zero. Found no increase in } \\
\text { suicidality in Greece during the recession } \\
\text { and no relationship of suicidal rates with } \\
\text { unemployment rates or growth rate. }\end{array}$ & $\begin{array}{l}\text { Evaluates specific } \\
\text { effects of } \\
\text { unemployment and } \\
\text { growth rates, on suicide } \\
\text { rates over recession } \\
\text { period. }\end{array}$ & $\begin{array}{l}\text { Because of its ecological } \\
\text { nature, the quality of data is } \\
\text { not assessable and no } \\
\text { implications on causality } \\
\text { can be drawn. Results } \\
\text { should be interpreted with } \\
\text { caution as other variables, } \\
\text { independent of economic } \\
\text { conditions, may be involved } \\
\text { in the precipitation of } \\
\text { suicide. The time series is } \\
\text { limited to a decade. }\end{array}$ \\
\hline [74] & $\begin{array}{l}\text { National population } \\
\text { sample, England, } \\
\text { UK }\end{array}$ & $\begin{array}{l}\text { Ecological } \\
\text { study }\end{array}$ & 1993-2010 & $\begin{array}{l}\text { Macroeconomic } \\
\text { indicators } \\
\text { National } \\
\text { unemployment rate }\end{array}$ & $\begin{array}{l}\text { Suicidal Behaviours } \\
\text { National suicide rates }\end{array}$ & $\begin{array}{l}\text { The associations between unemployment } \\
\text { rate and suicide rates were only } \\
\text { statistically significant associations at } \\
\text { regional level between } 2008 \text { and } 2010 \text {. }\end{array}$ & $\begin{array}{l}\text { National and regional } \\
\text { level trends analysis } \\
\text { covering the period of } \\
\text { recession. }\end{array}$ & $\begin{array}{l}\text { Because of its ecological } \\
\text { nature, the quality of data is } \\
\text { not assessable and no } \\
\text { implications on causality } \\
\text { can be drawn. Results } \\
\text { should be interpreted with } \\
\text { caution as other variables, } \\
\text { independent of economic } \\
\text { conditions, may be involved } \\
\text { in the precipitation of } \\
\text { suicide. }\end{array}$ \\
\hline [75] & $\begin{array}{l}\text { National population } \\
\text { sample, Hungary }\end{array}$ & $\begin{array}{l}\text { Ecological } \\
\text { study }\end{array}$ & 2000-2011 & $\begin{array}{l}\text { Macroeconomic } \\
\text { indicators } \\
\text { National } \\
\text { unemployment rate }\end{array}$ & $\begin{array}{l}\text { Suicidal Behaviours } \\
\text { National suicide rates }\end{array}$ & $\begin{array}{l}\text { Unemployment rates might } \\
\text { be associated with suicidality } \\
\text { in the general population after } \\
3-5 \text { years after the onset of } \\
\text { recession (strong positive } \\
\text { correlation at } 5 \text { years for the } \\
\text { general population }(0.78) \text { ) }\end{array}$ & $\begin{array}{l}\text { National level trends } \\
\text { analysis covering the } \\
\text { period of recession and } \\
\text { suggesting that there is } \\
\text { a time lag in the } \\
\text { increase of suicide rates. }\end{array}$ & $\begin{array}{l}\text { The time series is limited to } \\
\text { a decade Because of its } \\
\text { ecological nature, the } \\
\text { quality of data is not } \\
\text { assessable and no } \\
\text { implications on causality } \\
\text { can be drawn. Results } \\
\text { should be interpreted with } \\
\text { caution as other variables, } \\
\text { independent of economic } \\
\text { conditions, may be involved } \\
\text { in the precipitation of } \\
\text { suicide. }\end{array}$ \\
\hline
\end{tabular}


Table 3 Characteristics of studies included in review relating macroeconomic indicators and mental health outcomes, $2004-2014$ (Continued)

\begin{tabular}{|c|c|c|c|c|c|c|c|c|}
\hline [76] & $\begin{array}{l}\text { National population } \\
\text { sample, USA }\end{array}$ & $\begin{array}{l}\text { Ecological } \\
\text { study }\end{array}$ & 2005-2010 & $\begin{array}{l}\text { Macroeconomic } \\
\text { indicators } \\
\text { State level } \\
\text { foreclosure rate }\end{array}$ & $\begin{array}{l}\text { Suicidal Behaviours } \\
\text { State level suicide rates }\end{array}$ & $\begin{array}{l}\text { The foreclosure crisis has likely } \\
\text { contributed to increased suicides } \\
(b=0.04 ; P<.1) \text {. the effects were } \\
\text { strongest among the middle- } \\
\text { aged people ( } 46-64 \text { years: total } \\
\text { foreclosure rate, } b=0.21 \text {; } \\
P<.001 \text { ) }\end{array}$ & $\begin{array}{l}\text { State-level analysis } \\
\text { covering 2005-2010 on } \\
\text { suicide state rates. }\end{array}$ & $\begin{array}{l}\text { Because of its ecological } \\
\text { nature, the quality of data is } \\
\text { not assessable and no } \\
\text { implications on causality } \\
\text { can be drawn. Results } \\
\text { should be interpreted with } \\
\text { caution as other variables, } \\
\text { independent of economic } \\
\text { conditions, may be involved } \\
\text { in the precipitation of } \\
\text { suicide. The time series is } \\
\text { limited to } 5 \text { years }\end{array}$ \\
\hline [77] & $\begin{array}{l}\text { National population } \\
\text { sample, Italy }\end{array}$ & $\begin{array}{l}\text { Ecological } \\
\text { study }\end{array}$ & 2000-2010 & $\begin{array}{l}\text { Macroeconomic } \\
\text { indicators } \\
\text { GDP per person }\end{array}$ & $\begin{array}{l}\text { Suicidal Behaviours } \\
\text { National suicide rates }\end{array}$ & $\begin{array}{l}\text { The real GDP was associated } \\
\text { with the percentage of male } \\
\text { completed suicides due to } \\
\text { financial problems } b=0.16 \text {, } \\
p=0.05 \text { ). }\end{array}$ & $\begin{array}{l}\text { National level trends } \\
\text { analysis covering the } \\
\text { period of recession }\end{array}$ & $\begin{array}{l}\text { Only male suicides were } \\
\text { considered. The time series } \\
\text { is limited to a decade. The } \\
\text { ecological design does not } \\
\text { allow for control of } \\
\text { potential confounders or } \\
\text { effect modifiers. Results } \\
\text { should be interpreted with } \\
\text { caution as other variables, } \\
\text { independent of economic } \\
\text { conditions, may be involved } \\
\text { in the precipitation of } \\
\text { suicide. }\end{array}$ \\
\hline
\end{tabular}


Table 4 Characteristics of studies included in review relating unemployment status and mental health outcomes, 2004-2014

\begin{tabular}{|c|c|c|c|c|c|c|c|c|}
\hline Study & Setting & $\begin{array}{l}\text { Study } \\
\text { design }\end{array}$ & $\begin{array}{l}\mathrm{N} \\
\text { Year } \\
\text { Age }\end{array}$ & $\begin{array}{l}\text { Socioeconomic } \\
\text { determinants }\end{array}$ & $\begin{array}{l}\text { Mental health } \\
\text { outcomes }\end{array}$ & Associations/Effects & Strengths & Limitations \\
\hline [78] & $\begin{array}{l}\text { National } \\
\text { population } \\
\text { sample, USA }\end{array}$ & Cohort & $\begin{array}{l}1510 \\
(1986-2002) \\
>25 y\end{array}$ & $\begin{array}{l}\text { Individual-level } \\
\text { indicators } \\
\text { Employment status } \\
\text { Socioeconomic status }\end{array}$ & $\begin{array}{l}\text { Psychological } \\
\text { Well-being } \\
\text { Depressive } \\
\text { symptoms } \\
\text { (CES-D) }\end{array}$ & $\begin{array}{l}\text { Job loss is linked with follow-up } \\
\text { depressive symptoms and, } \\
\text { occupational prestige significantly } \\
\text { heightened this vulnerability. } \\
\text { Unemployment status is significantly } \\
\text { associated with depressive symptoms } \\
\text { (r: } 0.333, \text { S.E: } 0.108)\end{array}$ & $\begin{array}{l}\text { Temporal order of exposures, } \\
\text { confounders, and the outcome } \\
\text { under consideration affected all } \\
\text { participants at the same time } \\
\text { producing stronger causal } \\
\text { conclusions. }\end{array}$ & $\begin{array}{l}\text { Difficult to distinguish } \\
\text { truly involuntary job } \\
\text { losses from health- } \\
\text { related separations. } \\
\text { Did not account for } \\
\text { life course effects, the } \\
\text { role of neighbourhood, } \\
\text { or other such effects by } \\
\text { which inequality may } \\
\text { shape health. }\end{array}$ \\
\hline [79] & $\begin{array}{l}\text { National } \\
\text { population } \\
\text { sample, } \\
\text { Australia }\end{array}$ & Cohort & $\begin{array}{l}7176 \\
2001 \\
20-55 y\end{array}$ & $\begin{array}{l}\text { Individual-level } \\
\text { indicators } \\
\text { Employment status }\end{array}$ & $\begin{array}{l}\text { Psychological } \\
\text { Well-being } \\
\text { Mental health } \\
\text { distress (MHI-5) }\end{array}$ & $\begin{array}{l}\text { Negative correlation ( } r=-0.16) \\
\text { between unemployment and } \\
\text { mental health across waves. } \\
\text { Mental health is both a } \\
\text { consequence of and risk } \\
\text { factor for unemployment. }\end{array}$ & $\begin{array}{l}\text { Uses a continuous measure } \\
\text { of mental health symptoms.lt } \\
\text { simultaneously investigates } \\
\text { the bi-directional effects of } \\
\text { unemployment and mental } \\
\text { health. }\end{array}$ & $\begin{array}{l}\text { The analyses was } \\
\text { restricted to working } \\
\text { age population ( } 20 \text { to } \\
55 \text { years at baseline). } \\
\text { The results and } \\
\text { recommendations } \\
\text { should not be } \\
\text { generalized to other } \\
\text { cohorts. }\end{array}$ \\
\hline [80] & $\begin{array}{l}\text { National } \\
\text { population } \\
\text { sample, } \\
\text { Britain, UK }\end{array}$ & Cohort & $\begin{array}{l}14,686 \\
(1991-2000) \\
\geq 16 y\end{array}$ & $\begin{array}{l}\text { Individual-level } \\
\text { indicators } \\
\text { Employment status } \\
\text { Financial situation }\end{array}$ & $\begin{array}{l}\text { Psychological } \\
\text { Well-being } \\
\text { Mental health } \\
\text { distress caseness } \\
\text { (GHQ-12) }\end{array}$ & $\begin{array}{l}\text { Job loss increased risk of distress } \\
\text { for men (OR }=3.15 ; 95 \% \mathrm{Cl} \text { : } \\
2.50-3.98) \text { and women } \\
\text { (OR=2.60; } 95 \% \mathrm{Cl} \text { : } \\
\text { 1.97-3.43). Moving to paid } \\
\text { work reduced risk of distress } \\
\text { for men (OR }=0.52 ; 95 \% \mathrm{Cl} \text { : } \\
0.41-0.68) \text { and for women } \\
(\mathrm{OR}=0.68 ; 95 \% \mathrm{Cl} \text { : 0.69-1.40). } \\
\text { Worse off unemployed men } \\
\text { are more distressed (OR=4.19; } \\
95 \% \mathrm{Cl}: 3.20-5.50) \text {. }\end{array}$ & $\begin{array}{l}\text { Temporal order of exposures, } \\
\text { confounders, and the outcome } \\
\text { under consideration affected all } \\
\text { participants at the same time } \\
\text { producing stronger causal } \\
\text { conclusions. }\end{array}$ & $\begin{array}{l}\text { Although, subjective } \\
\text { financial difficulty was } \\
\text { associated with } \\
\text { psychological distress, } \\
\text { whether it is causal } \\
\text { or the consequence } \\
\text { of negative affectivity } \\
\text { is not clear. }\end{array}$ \\
\hline [81] & $\begin{array}{l}\text { National } \\
\text { population } \\
\text { sample, New } \\
\text { Zealand }\end{array}$ & Cohort & $\begin{array}{l}15,095 \\
(2004-2009) \\
15-60 y\end{array}$ & $\begin{array}{l}\text { Individual-level } \\
\text { indicators } \\
\text { Employment Status } \\
\text { Deprivation }\end{array}$ & $\begin{array}{l}\text { Psychological } \\
\text { Well-being } \\
\text { Mental health } \\
\text { distress (Kessler-10 } \\
\text { and SF-36) }\end{array}$ & $\begin{array}{l}\text { Job loss decreased MH (SF-36) } \\
\text { in } 1.34 \text { points ( } 95 \% \mathrm{Cl}-1.85 \\
\text { to }-0.82 \text { ) and increased mental } \\
\text { distress in } 0.50 \text { points ( } 95 \% \mathrm{Cl} \\
0.34 \text { to } 0.67) \text {. Deprivation was } \\
\text { associated with a } 1.47 \\
\text { ( } 95 \% \mathrm{Cl}-1.67 \text { to }-1.28 \text { ) } \\
\text { decline in } \mathrm{MH} \text { and a } 0.57 \\
\text { unit }(95 \% \mathrm{Cl} 0.51 \text { to } 0.63 \text { ) } \\
\text { increase in mental distress. }\end{array}$ & $\begin{array}{l}\text { Large sample over } 5 \text { years. } \\
\text { Temporal order of exposures, } \\
\text { confounders, and the outcome } \\
\text { under consideration affected all } \\
\text { participants at the same time } \\
\text { producing stronger causal } \\
\text { conclusions. }\end{array}$ & $\begin{array}{l}\text { Those with poor mental } \\
\text { health are more likely } \\
\text { to subsequently } \\
\text { become unemployed } \\
\text { or experience more } \\
\text { deprivation, so reverse } \\
\text { causation might be } \\
\text { possible. }\end{array}$ \\
\hline
\end{tabular}


Table 4 Characteristics of studies included in review relating unemployment status and mental health outcomes, $2004-2014$ (Continued)

\begin{tabular}{|c|c|c|c|c|c|c|}
\hline [82] & $\begin{array}{l}\text { National } \\
\text { population } \\
\text { sample, } \\
\text { Britain, UK }\end{array}$ & Cohort & $\begin{array}{l}10,300 \\
16-64 y \\
(1991-2009)\end{array}$ & $\begin{array}{l}\text { Individual-level } \\
\text { indicators } \\
\text { Employment Status }\end{array}$ & $\begin{array}{l}\text { Psychological } \\
\text { Well-being } \\
\text { Mental health } \\
\text { distress (GHQ-12) }\end{array}$ & $\begin{array}{l}\text { Moving from unemployment } \\
\text { to employment was strongly } \\
\text { associated with an improvement } \\
\text { in mental health }-2.1 \text { [ } 95 \% \mathrm{Cl}-2.4 \\
\text { to }-1.7] \text {, whereas becoming } \\
\text { unemployed was detrimental } \\
2.5 \text { ( } 95 \% \mathrm{Cl} 2.2-2.7) \text {. }\end{array}$ \\
\hline [83] & $\begin{array}{l}\text { National } \\
\text { population } \\
\text { sample, } \\
\text { Britain, UK }\end{array}$ & Cohort & $\begin{array}{l}10,264 \\
16-65 y \\
(1991-2007)\end{array}$ & $\begin{array}{l}\text { Individual-level } \\
\text { indicators } \\
\text { Employment Status }\end{array}$ & $\begin{array}{l}\text { Psychological } \\
\text { Well-being } \\
\text { Mental health } \\
\text { distress (GHQ-12) }\end{array}$ & $\begin{array}{l}\text { Job loss significantly } \\
\text { predicted } \\
\text { poorer psychological } \\
\text { well-being in comparison to those } \\
\text { employed }(2.21 ; 95 \% ; \mathrm{Cl}: 1.99-2.43)\end{array}$ \\
\hline [84] & $\begin{array}{l}\text { National } \\
\text { population } \\
\text { sample, } \\
\text { Japan }\end{array}$ & Cohort & $\begin{array}{l}4800 \\
(2007-2011) \\
20-40 y\end{array}$ & $\begin{array}{l}\text { Individual-level } \\
\text { indicators } \\
\text { Employment Status }\end{array}$ & $\begin{array}{l}\text { Psychological } \\
\text { Well-being } \\
\text { Mental health } \\
\text { distress (MHI-5) }\end{array}$ & $\begin{array}{l}\text { Job loss decreases mental health } \\
\text { by } 12.0 \text { points (MHI-5) after } \\
\text { controlling for other variables. }\end{array}$ \\
\hline [85] & $\begin{array}{l}\text { National } \\
\text { population } \\
\text { sample, } \\
\text { Australia }\end{array}$ & Cohort & $\begin{array}{l}5846 \\
2007>15 y\end{array}$ & $\begin{array}{l}\text { Individual-level } \\
\text { indicators } \\
\text { Employment } \\
\text { status } \\
\text { Unemployment } \\
\text { duration }\end{array}$ & $\begin{array}{l}\text { Psychological } \\
\text { Well-being } \\
\text { Mental health } \\
\text { distress (MHI-5) }\end{array}$ & $\begin{array}{l}\text { Baseline mental health status } \\
\text { predicts overall time spent } \\
\text { unemployed. } 19.1 \% \text { of those } \\
\text { with poor mental health } \\
\text { experience subsequent } \\
\text { unemployment compared } \\
\text { with } 14.6 \% \text { of those with } \\
\text { better mental health. }\end{array}$ \\
\hline [86] & $\begin{array}{l}\text { National } \\
\text { population } \\
\text { sample, } \\
\text { Australia }\end{array}$ & Cohort & $\begin{array}{l}21,280 \\
(2001-2010) \geq 16 y\end{array}$ & $\begin{array}{l}\text { Individual-level } \\
\text { indicators } \\
\text { Employment } \\
\text { status Number } \\
\text { of unemployment } \\
\text { spells }\end{array}$ & $\begin{array}{l}\text { Psychological } \\
\text { Well-being } \\
\text { Mental well-being } \\
\text { (SF-36) }\end{array}$ & $\begin{array}{l}\text { Compared to employed } \\
\text { people, unemployed people } \\
\text { show a } 1.64 \text { decrease } \\
(95 \% \mathrm{Cl}-2.05 \text { to }-1.23 \text {, } \\
p<0.001) \text { in mental health, } \\
\text { and those who had two or } \\
\text { more spells of unemployment } \\
\text { show a } 2.56 \text { decrease } \\
(95 \% \mathrm{Cl}-3.93 \text { to }-1.19 \text {, } \\
p<0.001) \text {. }\end{array}$ \\
\hline
\end{tabular}

Annual data collected over a 19-year period. Temporal order of exposures,

confounders, and the

outcome under consideration affected all participants at the same time producing

stronger causal conclusions.

Annual data collected over a 16-year period. Temporal orde of exposures, confounders, and

the outcome under

consideration affected all participants at the same time producing stronger causal conclusions.

Temporal order of exposures, confounders, and the outcome under consideration affected all participants at the same time producing stronger causal conclusions.

Temporal order of exposures, confounders, and the outcome under consideration affected all participants at the same time producing stronger causal link.

Large sample. Temporal order of exposures, confounders, and the outcome under consideration affected all participants at the same time producing stronger causal conclusions.
Possible bias due to selection effects threat causal inference since those with poor ment health are more likely to subsequently become unemployed.

Possible bias due to selection effects threat causal inference since

those with poor menta

health are more likely

to subsequently

become unemployed.

Direction of causality even after controlling for individual heterogeneity, is difficult to distinguish.

The analysis was restricted to respondents aging 20-50 years at baseline. The results and recommendations should not be generalized to other cohorts.

Lack of data on voluntarily or involuntary job loss (due to illness) self-reported nature of the data on mental health. 
Table 4 Characteristics of studies included in review relating unemployment status and mental health outcomes, $2004-2014$ (Continued)

\begin{tabular}{|c|c|c|c|c|c|c|c|c|}
\hline [87] & $\begin{array}{l}\text { National } \\
\text { population, } \\
\text { Sweden }\end{array}$ & $\begin{array}{l}\text { Cross- } \\
\text { sectional }\end{array}$ & $\begin{array}{l}20,538 \\
(2008) \\
18-85 y\end{array}$ & $\begin{array}{l}\text { Individual-level } \\
\text { indicators } \\
\text { Employment status }\end{array}$ & $\begin{array}{l}\text { Psychological } \\
\text { Well-being } \\
\text { Mental health } \\
\text { distress (GHQ-12) } \\
\text { psychosomatic } \\
\text { symptoms }\end{array}$ & $\begin{array}{l}\text { Unemployed people had } \\
\text { reduced psychological } \\
\text { well-being }(\mathrm{OR}=2.11 \text {; } \\
95 \% \mathrm{Cl}: 1.79-2.50) \text { and } \\
\text { more psychosomatic } \\
\text { symptoms }(\mathrm{OR}=1.62 ; \\
95 \% \mathrm{Cl} \text { : } 1.37-1.92) \\
\text { compared with individuals } \\
\text { who were employed. }\end{array}$ & $\begin{array}{l}\text { Large sample. The postal } \\
\text { survey reduces the potential } \\
\text { bias introduced by interviewer } \\
\text { and respondents may answer } \\
\text { sensitive questions more } \\
\text { honestly. }\end{array}$ & $\begin{array}{l}\text { Its cross-sectional } \\
\text { design removes the } \\
\text { possibility of causal } \\
\text { inference.Postal } \\
\text { questionnaire surveys } \\
\text { increase non-response } \\
\text { sample bias. }\end{array}$ \\
\hline [88] & $\begin{array}{l}\text { Community } \\
\text { sample, } \\
\text { Scania, } \\
\text { Sweden }\end{array}$ & $\begin{array}{l}\text { Cross- } \\
\text { sectional }\end{array}$ & $\begin{array}{l}5180 \\
18-64 \text { y }\end{array}$ & $\begin{array}{l}\text { Individual-level } \\
\text { indicators } \\
\text { Employment } \\
\text { status } \\
\text { Psychosocial } \\
\text { job quality }\end{array}$ & $\begin{array}{l}\text { Psychological } \\
\text { Well-being } \\
\text { Mental health } \\
\text { distress (GHQ-12) }\end{array}$ & $\begin{array}{l}\text { People facing job strain } \\
(\mathrm{OR}=3.01 ; 95 \% \mathrm{Cl}: 2.26-4.02) \\
\text { and unemployment }(\mathrm{OR}=5.81 ; \\
95 \% \mathrm{Cl}: 4.33-7.79) \text { have } \\
\text { significantly higher odds } \\
\text { ratios of psychological distress. }\end{array}$ & $\begin{array}{l}\text { The postal survey reduces } \\
\text { the potential bias introduced } \\
\text { by interviewer and respondents } \\
\text { may answer sensitive questions } \\
\text { more honestly. }\end{array}$ & $\begin{array}{l}\text { Its cross-sectional } \\
\text { design removes the } \\
\text { possibility of causal } \\
\text { inference.Postal } \\
\text { questionnaire surveys } \\
\text { increase non-response } \\
\text { sample bias. }\end{array}$ \\
\hline [89] & $\begin{array}{l}\text { Regional } \\
\text { sample, } \\
\text { North West } \\
\text { of England, } \\
\text { UK }\end{array}$ & $\begin{array}{l}\text { Cross- } \\
\text { sectional }\end{array}$ & $\begin{array}{l}15,228 \\
(2009)\end{array}$ & $\begin{array}{l}\text { Individual-level } \\
\text { indicators } \\
\text { Employment status } \\
\text { Deprivation }\end{array}$ & $\begin{array}{l}\text { Psychological } \\
\text { Well-being } \\
\text { Life satisfaction } \\
\text { Mental well-being }\end{array}$ & $\begin{array}{l}\text { Deprivation strongly linked to } \\
\text { low LS and MWB. } 17.1 \% \text { of } \\
\text { the most deprived tertile have } \\
\text { low LS compared to } 8.9 \% \text { in } \\
\text { the most affluent. }\end{array}$ & $\begin{array}{l}\text { It identifies the characteristics } \\
\text { of individuals most likely to } \\
\text { suffer from poor Well-being }\end{array}$ & $\begin{array}{l}\text { Its cross-sectional design } \\
\text { removes the possibility } \\
\text { of causal inference. }\end{array}$ \\
\hline [90] & $\begin{array}{l}\text { National } \\
\text { population } \\
\text { sample, } \\
\text { Brazil }\end{array}$ & $\begin{array}{l}\text { Cross- } \\
\text { sectional }\end{array}$ & $\begin{array}{l}5000 \\
(2003)>18 y\end{array}$ & $\begin{array}{l}\text { Individual-level } \\
\text { indicators } \\
\text { Employment status }\end{array}$ & $\begin{array}{l}\text { Common Mental } \\
\text { Disorders } \\
\text { State of animus } \\
\text { (World Health } \\
\text { Survey) }\end{array}$ & $\begin{array}{l}\text { Among women, level of } \\
\text { education and unemployment } \\
\text { were associated to feelings of } \\
\text { depression and anxiety. Among } \\
\text { males, feelings of depression } \\
\text { were strongly associated with } \\
\text { unemployment. }\end{array}$ & $\begin{array}{l}\text { This study provides data on } \\
\text { the negative effects of } \\
\text { unemployment on depression } \\
\text { and anxiety, which are } \\
\text { important predictors of } \\
\text { subsequent morbidity. }\end{array}$ & $\begin{array}{l}\text { Its cross-sectional design } \\
\text { removes the possibility } \\
\text { of causal inference. } \\
\text { Generalizing findings } \\
\text { may be reasonably } \\
\text { limited to the } \\
\text { uniqueness of the } \\
\text { Brazilian welfare } \\
\text { system. }\end{array}$ \\
\hline [91] & $\begin{array}{l}\text { Cross- } \\
\text { national } \\
\text { samples of } \\
\text { older adults } \\
\text { from } 13 \text { EU } \\
\text { countries } \\
\text { and USA }\end{array}$ & Cohort & $\begin{array}{l}15,055 \\
(2006-2010) \\
50-64 \text { y }\end{array}$ & $\begin{array}{l}\text { Individual-level } \\
\text { indicators } \\
\text { Employment status }\end{array}$ & $\begin{array}{l}\text { Common } \\
\text { Mental } \\
\text { Disorders } \\
\text { Depressive } \\
\text { symptoms } \\
\text { (EURO-D and } \\
\text { CESD) }\end{array}$ & $\begin{array}{l}\text { Unemployment was associated } \\
\text { with } 4.78 \% \text { [ } 95 \% \text { (CI): } 0.823 \text { to } \\
8.74 \% \text { increase in depressive } \\
\text { symptoms in the USA and } \\
3.35 \% \text { ( } 95 \% \text { Cl: } 0.486 \text { to } \\
6.22 \%) \text { increase in Europe. }\end{array}$ & $\begin{array}{l}\text { Bias due to selection and reverse } \\
\text { causality was lessen because the } \\
\text { study distinguished job loss due } \\
\text { to plant closures, and used } \\
\text { individual fixed effect models. }\end{array}$ & $\begin{array}{l}\text { Used two measures } \\
\text { for depressive } \\
\text { symptoms Euro-D } \\
\text { for Europe and CESD } \\
\text { for USA. However, } \\
\text { these were normalized. } \\
\text { The analysis was } \\
\text { restricted to older } \\
\text { adults (50-64y). }\end{array}$ \\
\hline
\end{tabular}


Table 4 Characteristics of studies included in review relating unemployment status and mental health outcomes, $2004-2014$ (Continued)

\begin{tabular}{|c|c|c|c|c|c|c|c|c|}
\hline [92] & $\begin{array}{l}\text { Cross- } \\
\text { national } \\
\text { sample } \\
\text { ofprimary } \\
\text { care patients } \\
\text { from EU and } \\
\text { Chile }\end{array}$ & Cohort & $\begin{array}{l}10,059 \\
(2003-2004) \\
18-75 y\end{array}$ & $\begin{array}{l}\text { Individual-level } \\
\text { indicators } \\
\text { Employment status }\end{array}$ & $\begin{array}{l}\text { Common } \\
\text { Mental } \\
\text { Disorders } \\
\text { Depression } \\
\text { caseness } \\
\text { Composite } \\
\text { International } \\
\text { Diagnostic } \\
\text { Interview } \\
\text { (CIDI) }\end{array}$ & $\begin{array}{l}\text { Job loss between baseline } \\
\text { and } 6 \text { months compared to } \\
\text { those employed at both } \\
\text { times had an adj relative } \\
\text { risk ratio for } 12 \text {-month } \\
\text { depression of } 1.58 \\
\text { ( } 95 \% \text { Cl:0.76, } 3.27) \text {. } \\
\text { Participants with depression } \\
\text { at baseline and } 6 \text { months } \\
\text { compared to neither time } \\
\text { had an OR for } 6 \text {-month } \\
\text { unemployment of } 1.58 \\
\text { (95\% Cl:0.97, 2.58). }\end{array}$ & $\begin{array}{l}\text { It examines the interrelations } \\
\text { between unemployment and } \\
\text { clinical depression in both } \\
\text { directions across different } \\
\text { countries producing stronger } \\
\text { causal conclusions. }\end{array}$ & $\begin{array}{l}\text { No available data on } \\
\text { whether employment } \\
\text { is full time or part-time } \\
\text { or underemployment. } \\
\text { If unemployed adults } \\
\text { with depression are } \\
\text { less likely to seek } \\
\text { medical treatment } \\
\text { they may be under- } \\
\text { represented in the } \\
\text { GP-based sampling } \\
\text { frame. }\end{array}$ \\
\hline [95] & $\begin{array}{l}\text { Cross- } \\
\text { national } \\
\text { samples of } \\
\text { European } \\
\text { Countries }\end{array}$ & $\begin{array}{l}\text { Cross- } \\
\text { sectional }\end{array}$ & $\begin{array}{l}34,395 \\
(2001-2009)>18 y\end{array}$ & $\begin{array}{l}\text { Individual-level } \\
\text { indicators } \\
\text { Employment } \\
\text { status } \\
\text { Education level } \\
\text { Income and } \\
\text { Occupation }\end{array}$ & $\begin{array}{l}\text { Common } \\
\text { Mental } \\
\text { Disorders } \\
\text { Anxiety } \\
\text { Mood disorder }\end{array}$ & $\begin{array}{l}\text { Unemployed showed the } \\
\text { highest prevalence and } \\
\text { increased risk of 12-month } \\
\text { mental disorders. Mood } \\
\text { disorders and anxiety were } \\
\text { more prevalent among those } \\
\text { receiving a low and a low- } \\
\text { average incomeNorthern Ireland, } \\
\text { Portugal and Belgium were the } \\
\text { countries with the highest risk } \\
\text { for mental disorders. }\end{array}$ & $\begin{array}{l}\text { This study examines the } \\
\text { associations between } \\
\text { employment status and } \\
\text { mental health in a European } \\
\text { representative sample. } \\
\text { Specifies which countries } \\
\text { are at higher risk for mental } \\
\text { disorders. }\end{array}$ & $\begin{array}{l}\text { Since data derives } \\
\text { from different } \\
\text { countries during a } \\
\text { wide time interval } \\
\text { (2001-2009) to } \\
\text { determine the impact } \\
\text { of the adverse } \\
\text { economic conditions } \\
\text { of the past few years } \\
\text { was not possible. } \\
\text { Participants from } \\
\text { different countries } \\
\text { have been exposed } \\
\text { to different economic } \\
\text { scenarios and the } \\
\text { study was unable to } \\
\text { evaluate the impact } \\
\text { of this.No causal } \\
\text { inference can be } \\
\text { made due to the } \\
\text { cross-sectional nature } \\
\text { of the study }\end{array}$ \\
\hline [93] & $\begin{array}{l}\text { National } \\
\text { population } \\
\text { sample, } \\
\text { England, UK }\end{array}$ & $\begin{array}{l}\text { Cross- } \\
\text { sectional }\end{array}$ & $5090 \geq 16 y$ & $\begin{array}{l}\text { Individual-level } \\
\text { indicators } \\
\text { Employment status }\end{array}$ & $\begin{array}{l}\text { Common } \\
\text { Mental } \\
\text { Disorders } \\
\text { CIS-R interview: } \\
\text { Common Mental } \\
\text { Disorders (CMD) }\end{array}$ & $\begin{array}{l}\text { Risk of CMD was significantly greater in } \\
\text { unemployed individuals; economically } \\
\text { inactive; not working due to physical } \\
\text { health reasons; unable to find a suitable } \\
\text { job among others. Individuals } \\
\text { unemployed for less than } 1 \text { year or more } \\
\text { than } 3 \text { years had a higher risk of CMD. }\end{array}$ & $\begin{array}{l}\text { Uses a well validated scale for } \\
\text { detection of common mental } \\
\text { disorders. }\end{array}$ & $\begin{array}{l}\text { Its cross-sectional } \\
\text { design removes the } \\
\text { possibility of causal } \\
\text { inference. }\end{array}$ \\
\hline [94] & $\begin{array}{l}\text { National } \\
\text { population } \\
\text { sample, } \\
\text { Sweden }\end{array}$ & $\begin{array}{l}\text { Cross- } \\
\text { sectional }\end{array}$ & $\begin{array}{l}42,448 \\
(2004) \\
18-84 y\end{array}$ & $\begin{array}{l}\text { Individual-level } \\
\text { indicators } \\
\text { Employment status } \\
\text { Financial strain }\end{array}$ & $\begin{array}{l}\text { Common } \\
\text { Mental } \\
\text { Disorders } \\
\text { Anxiety Depression } \\
\text { (EQ-5D) }\end{array}$ & $\begin{array}{l}\text { Unemployment (OR=2.9; } \\
95 \% ; \mathrm{Cl}: 2.2-4.0) \text {, economic } \\
\text { hardship (OR = 3.1; } 95 \% \text {; Cl: } \\
2.4-3.9 \text { were strongly and } \\
\text { independently related with } \\
\text { anxiety/depression. }\end{array}$ & $\begin{array}{l}\text { Large and population-based } \\
\text { study that uses an internationally } \\
\text { validated scale of quality of life } \\
\text { that measures anxiety and } \\
\text { depression. }\end{array}$ & $\begin{array}{l}\text { No causal inference } \\
\text { can be made due to } \\
\text { the cross-sectional } \\
\text { nature of the study. }\end{array}$ \\
\hline
\end{tabular}


Table 4 Characteristics of studies included in review relating unemployment status and mental health outcomes, $2004-2014$ (Continued)

pross- 1880

of employees

of collapsed

major banks,

Iceland

[97] Nation

Case-

control 74,809

sample,

controls

Finland

indicators

Driving under the

Employment status influence of drugs

Socioeconomic status (DUID)
Low education, unemployment,

disability pension, being divorced

and living alone were the strongest

individual predictors of DUID in

all substance groups.

nemployed people show

Substance-Disorders

Employment status dependence; illicit drug use, illicit drug use, tobacco

use/abuse/dependence use, alcohol abuse or

and tobacco use

dependence, and illicit drug

abuse or dependence then

employed. This was before

at the start of, and during

the 2009-2010 period of

high unemployment.

$\begin{array}{llll}\text { [99] } & \begin{array}{l}\text { National } \\ \text { population }\end{array} & \begin{array}{l}\text { Cross- } \\ \text { sectional }\end{array} & \text { (2009-2010 }\end{array}$ sample, USA $>18 \mathrm{y}$

ndividual-level

indicators

Employment status

Substance-Disorders Alcohol Dependence

Housing payment instability

was associated with experiencing

more negative drinking

consequences and alcoho

dependence symptoms.Job

loss was strongly associated

with alcohol problems in

univariate models, but no

significant associations were

observed in multivariate models.

problems
Nationwide sample and the inclusion of all employees of collapsed major banks in one country highly hit by the economic recession

Large sample size, based on two registers ensuring good coverage and validity, increases reliability of the study.lt shows that disadvantaged social background is related to driving under the influence of drugs.

Nationally representative sample of US adults. Strong association between substance disorders and unemployment.

Nationally representative sample of US adults. Strong association between alcohol drinking patterns and housing instability and unemployment.
No causal inference can be made the cross-sectional design and self-

reported data.This sample was drawn from the collapse of banks in Iceland, so generalizing findings to other countires may be limited

Impaired drivers were over-represented: the cases were suspected and apprehended of DUID by the police.

Not all people driving under the influence are caught (fewer than $10 \%$ ). The direction of causality remains unclear.

Cross-sectional data does not allow tests of causality among the reported associations. Possible bias due to validity of self-reports of sensitive behaviours

Does not preclud the possibility of reverse causation (individuals with existing alcohol problems prior to the study) 
Table 4 Characteristics of studies included in review relating unemployment status and mental health outcomes, $2004-2014$ (Continued)

\begin{tabular}{|c|c|c|c|c|c|c|}
\hline [100] & $\begin{array}{l}\text { Community } \\
\text { sample of } \\
\text { job-seekers, } \\
\text { Germany }\end{array}$ & $\begin{array}{l}\text { Cross- } \\
\text { sectional }\end{array}$ & $\begin{array}{l}7906 \text { (2008-09) } \\
18-64 \text { y }\end{array}$ & $\begin{array}{l}\text { Individual-level } \\
\text { indicators } \\
\text { Employment status } \\
\text { Duration of } \\
\text { unemployment }\end{array}$ & $\begin{array}{l}\text { Substance-Disorders } \\
\text { Smoking, risky drinking, } \\
\text { illicit drug use.Self- } \\
\text { rated health }\end{array}$ & $\begin{array}{l}52.4 \% \text { of the sample ( } 53.4 \% \\
\text { male, } 33.5 \text { years mean age) had } \\
3 \text { or more health risk factors. } \\
84.8 \% \text { of the } 18-24 \text { year old } \\
\text { long-term unemployed men } \\
\text { were smokers. Substance use } \\
\text { risk factors were highest among } \\
\text { the } 18-24 \text { year olds All health } \\
\text { risk factors were associated with } \\
\text { lower self-rated health. }\end{array}$ \\
\hline [101] & $\begin{array}{l}\text { National } \\
\text { population } \\
\text { sample, } \\
\text { South Korea }\end{array}$ & $\begin{array}{l}\text { Ecological } \\
\text { Study }\end{array}$ & 1995-2005 & $\begin{array}{l}\text { Individual-level } \\
\text { indicators } \\
\text { Employment status }\end{array}$ & $\begin{array}{l}\text { Substance-Disorders } \\
\text { Alcohol-attributable } \\
\text { mortality }\end{array}$ & $\begin{array}{l}\text { Found an incidence of } 20 \text { times } \\
\text { higher alcohol-attributable deaths } \\
\text { rate of unemployed compared to } \\
\text { those of non-manual workers } \\
\text { during recession }\end{array}$ \\
\hline [102] & $\begin{array}{l}\text { Community } \\
\text { sample, } \\
\text { emergency } \\
\text { departments } \\
\text { in } \\
\text { Edmonton, } \\
\text { Canada }\end{array}$ & $\begin{array}{l}\text { Case- } \\
\text { control }\end{array}$ & $\begin{array}{l}507 \text { cases } \\
200 \text { controls } \\
(1993-94) \\
>16 y\end{array}$ & $\begin{array}{l}\text { Individual-level } \\
\text { indicators } \\
\text { Employment status }\end{array}$ & $\begin{array}{l}\text { Suicidal Behaviours } \\
\text { Parasuicide }\end{array}$ & $\begin{array}{l}\text { There is an association between } \\
\text { unemployment and parasuicide } \\
(\mathrm{OR}=12.0 ; 95 \% \mathrm{Cl}: 6.0-23.9)\end{array}$ \\
\hline [103] & $\begin{array}{l}\text { Cross- } \\
\text { national } \\
\text { samples from } \\
21 \text { countries } \\
\text { worldwide }\end{array}$ & $\begin{array}{l}\text { Cross- } \\
\text { sectional }\end{array}$ & $\begin{array}{l}108,705 \\
(2001-07) \\
>18 y\end{array}$ & $\begin{array}{l}\text { Individual-level } \\
\text { indicators } \\
\text { Employment status } \\
\text { Educational level }\end{array}$ & $\begin{array}{l}\text { Suicidal Behaviours } \\
\text { Suicidal ideation and } \\
\text { attempts(CIDI) }\end{array}$ & $\begin{array}{l}\text { 12-month prevalence of suicide } \\
\text { ideation, plans and attempts are } \\
2.0,0.6 \text { and } 0.3 \% \text { respectively for } \\
\text { developed countries and } 2.1,0.7 \\
\text { and } 0.4 \% \text { for developing countries. } \\
\text { Risk factors for suicidal behaviours } \\
\text { in both developed and developing } \\
\text { countries included being a woman, } \\
\text { low educated, low income, and } \\
\text { being unemployed (among others). }\end{array}$ \\
\hline
\end{tabular}
with health risk behaviours were found, and associations with sefreun, and associations with selsample of job-seeker individuals.

Brings national evidence on the inequalities in the health effects of economic changes.

Brings strong evidence on the influence of exposure to

unemployment on parasuicida behaviour in comparison to a control group.

\section{Large cross-national}

epidemiological

survey database
No causal inference can be made due to the cross-sectional

design.The validity of self-reports of sensitive behaviours, such as alcohol consumption. Since the research focused job-seekers the sample included both unemployed and employed individuals. This sample was drawn from one area in Germany so generalizing findings may be limited

Did not consider accidental deaths caused directly by alcohol (eg falls). The real magnitude of social disparity in alcohol-attributable death rates may be even greater than that estimated. Social disparity in alcoholattributable mortality cannot be said to be a result of the crisis because this was tested.

There is low response rate for both cases and controls.

No causal inference can be made due to the cross-sectional nature of the study.Reported suicidal ideation and suicide attempts can be susceptible to recall bias or to reluctance on the part of respondents to disclose such a sensitive information. 
Table 4 Characteristics of studies included in review relating unemployment status and mental health outcomes, $2004-2014$ (Continued)

\begin{tabular}{|c|c|c|c|c|c|c|c|c|}
\hline [104] & $\begin{array}{l}\text { National } \\
\text { population } \\
\text { sample, } \\
\text { Australia }\end{array}$ & $\begin{array}{l}\text { Cross- } \\
\text { sectional }\end{array}$ & $\begin{array}{l}4697 \\
(2007-2009) \\
15-64 \text { y }\end{array}$ & $\begin{array}{l}\text { Individual-level } \\
\text { indicators } \\
\text { Employment status }\end{array}$ & $\begin{array}{l}\text { Suicidal Behaviours } \\
\text { Death by Suicide }\end{array}$ & $\begin{array}{l}\text { During } 2001-10 \text { economically inactive/ } \\
\text { unemployed males suicide at } 4.62 \text { times } \\
\text { (RR }=4.62 ; 95 \% \text { Cl: } 4.10,5.19 ; P<0.001) \\
\text { the rate of employed men }(\mathrm{RR}=1.00) \text {. } \\
\text { Economically inactive/unemployed } \\
\text { females had a suicide RR of } 8.44 \\
\text { compared with employed females } \\
(95 \% \mathrm{Cl} 7.38,9.67 ; P<0.001) .\end{array}$ & $\begin{array}{l}\text { Best available national data } \\
\text { and provides information on } \\
\text { the employment status of } \\
\text { individual suicide cases. }\end{array}$ & $\begin{array}{l}\text { Possible under- } \\
\text { reporting of suicide } \\
\text { data and under-report } \\
\text { of the long-term } \\
\text { unemployed that have } \\
\text { given up looking for } \\
\text { work (i.e. discouraged } \\
\text { job seekers).Lack of } \\
\text { available data on } \\
\text { confounding factors. }\end{array}$ \\
\hline [105] & $\begin{array}{l}\text { National } \\
\text { population } \\
\text { sample, } \\
\text { Spain }\end{array}$ & $\begin{array}{l}\text { Cross- } \\
\text { sectional }\end{array}$ & $\begin{array}{l}4583 \\
(2001-2002) \\
>18 y\end{array}$ & $\begin{array}{l}\text { Individual-level } \\
\text { indicators } \\
\text { Employment status }\end{array}$ & $\begin{array}{l}\text { Suicidal Behaviours } \\
\text { Suicidal ideation and } \\
\text { attempts(CIDI) }\end{array}$ & $\begin{array}{l}\text { Being unemployed or having work } \\
\text { disability were also associated with } \\
\text { suicidal ideation in people aged } \\
18-49 \text {. The prevalence of suicidal } \\
\text { ideation and attempts found in } \\
\text { this study is similar to the one } \\
\text { found ten years ago, before the } \\
\text { economic crisis }\end{array}$ & $\begin{array}{l}\text { Representative sample of } \\
\text { the national population } \\
\text { in Spain during the economic } \\
\text { recession. The data was } \\
\text { collected in the same way as } \\
\text { in the ESEMED study, making } \\
\text { it possible to compare current } \\
\text { figures with the prevalence } \\
\text { found before the crisis. }\end{array}$ & $\begin{array}{l}\text { No causal inference } \\
\text { can be made due to } \\
\text { the cross-sectional } \\
\text { nature of the } \\
\text { study.Reported } \\
\text { suicidal ideation and } \\
\text { suicide attempts can } \\
\text { be susceptible to } \\
\text { recall bias or to } \\
\text { reluctance on the } \\
\text { part of respondents } \\
\text { to disclose such a } \\
\text { sensitive information. }\end{array}$ \\
\hline
\end{tabular}


outcomes and low life satisfaction, and suggest that this can be both a risk factor for being unemployed and its consequence [78-86]. In addition, in cross-sectional studies unemployment has also been associated with psychosomatic symptoms and psychological distress [87-90].

Two large cohort studies showed that unemployment was associated with depressive symptoms [91, 92]. The risk of common mental disorders such as depression and anxiety was also found to be significantly greater in unemployed individuals in several cross-sectional studies [93-96].

Furthermore, a case-control study from Finland found that being unemployed was a heavy predictor of risky behaviours such as driving under the influence of drugs [97]. Cross-sectional data from the USA and Germany also discovered that unemployment was significantly related to alcohol and drug use [98-100]. Additionally, alcohol-attributable deaths rate were determined to be higher among the unemployed population during recession, says an ecological study from South Korea [101].

Suicidal behaviours were also linked to unemployment in several studies. A Canadian case control study found that unemployed individuals have a significantly increased risk of parasuicidal behaviour compared to their matched controls [102]. Likewise, in a large cross-national study, being unemployed was discovered to be a strong risk factor for suicidal ideation and attempts [103]. An Australian study also revealed that, in times of recession, unemployed males commit suicide at 4.62 times the rate of employed men and women 8.44 times more compared with employed females [104]. Also in times of recession a Spanish study states that being unemployed was found to be associated with suicidal ideation [105].

\section{Precarious and insecure work}

Working conditions affect mental health (Table 5). Finnish longitudinal data pinpointed mental distress as being stronger among precarious workers with high job insecurity [106]. Nevertheless, there is a Swedish cohort study that found no significant differences in the effects of job insecurity on health between temporary and permanent workers [107]. Cross-sectional data from during the recession in Italy, determined that job stress was significantly related to workers' mental health and fear of the crisis [108]. This was supported by British evidence of an increased risk of depression and anxiety among such employees $[109,110]$.

\section{Debt, deprivation, and financial hardship}

Several studies found socioeconomic status and indebtedness to be related to mental health. In the USA, a cohort study, indicated increased incidence of anxiety and mood disorders, and substance use disorders were strongly associated with drops in household incomes [111]. Strong causal conclusions about this matter can also be drawn on the basis of a cohort study from New Zealand that shows a high level of association between inequalities in wealth and psychological distress, stating that people reporting low levels of wealth have three times greater distress than those reporting higher levels of wealth [112]. Longitudinal data also illustrates that housing payment problems and indebtedness have a detrimental effect on mental health [113] and on the onset of depression and anxiety [114].

Income inequality at a regional level was also significantly associated with poorer mental health in a crosssectional study completed in a community sample from Wales, UK [115]. Additionally, low socioeconomic status was related to higher rates of tobacco smoking and the use of cannabis and other illegal drugs compared to people of higher socioeconomic status in a French community-based cohort [116].

Furthermore, a cohort and a cross-sectional study from England found that people facing debt are also at higher risk of depression [110], and are twice as likely to think about suicide [117].

The previously cited studies show that during recession Greek people with serious economic difficulties had 1.33 times higher odds of developing a major depressive episode during the recession [38], and in South Korea well-off people do better in recessions in terms of the prevalence of depression, suicidal ideation, and suicide attempts [46].

\section{Families, children, and older people}

The literature also stated that families and children affected by socioeconomic factors might face a decline in their mental health (Table 6). Finnish longitudinal research shows that economic stress can lead to deterioration in children's mental health, mainly through changes in family relationships and parenting quality [118]. A large cross-national study with representative data on adolescents from 31 countries found that the countries most hit by the recession (Ireland and Portugal) faced a rise in psychological health complaints (9-17\%), and this was related to the increase in unemployment rates [119].

In fact, adolescents who perceived themselves as being socioeconomically worse off have a four-times higher likelihood of rating low life satisfaction and quality of life, claims a study from Slovenia [120]. In addition, children with unemployed parents have a higher prevalence of depression, higher rates of psychosomatic symptoms, and lower perceptions of psychological well-being [121-123].

Trends in a cohort of Canadian adolescents' total suiciderelated behaviour during periods of recession illustrate that the downward trends in suicidal behaviour stopped after the onset of the recession, though no increase has been reported [124]. Moreover, in the USA, repeated cross- 
Table 5 Characteristics of studies included in review relating job quality and security, deprivation and socioeconomic status and mental health outcomes, 2004-2014

\begin{tabular}{|c|c|c|c|c|c|c|c|c|}
\hline Study & Setting & $\begin{array}{l}\text { Study } \\
\text { design }\end{array}$ & $\begin{array}{l}\text { N } \\
\text { Year } \\
\text { Age }\end{array}$ & $\begin{array}{l}\text { Socioeconomic } \\
\text { determinants }\end{array}$ & $\begin{array}{l}\text { Mental health } \\
\text { outcomes }\end{array}$ & Associations/Effects & Strengths & Limitations \\
\hline [106] & $\begin{array}{l}\text { National } \\
\text { population } \\
\text { sample, } \\
\text { Finland }\end{array}$ & Cohort & $\begin{array}{l}3449 \\
31 \mathrm{y}\end{array}$ & $\begin{array}{l}\text { Individual-level indicators } \\
\text { Psychosocial job quality } \\
\text { and Security }\end{array}$ & $\begin{array}{l}\text { Psychological } \\
\text { Well-being } \\
\text { Mental health } \\
\text { distress caseness } \\
\text { (HSCL-25) } \\
\text { Self-reports of GP }\end{array}$ & $\begin{array}{l}\text { The precarious workers have } \\
\text { more distress symptoms in } \\
\text { comparison with permanent } \\
\text { workers. No differences in } \\
\text { doctor-diagnosed/treated } \\
\text { illnesses between precarious } \\
\text { and permanent workers. }\end{array}$ & $\begin{array}{l}\text { It measures mental } \\
\text { health and correlates } \\
\text { with self-reports of } \\
\text { doctor diagnosed/treated } \\
\text { illnesses.Temporal order } \\
\text { of exposures and } \\
\text { confounders affected all } \\
\text { participants at the same } \\
\text { time producing stronger } \\
\text { causal conclusions. }\end{array}$ & $\begin{array}{l}\text { Cannot make differential } \\
\text { analysis of health-based } \\
\text { selection.The results and } \\
\text { recommendations should } \\
\text { not be generalized to } \\
\text { other cohorts. }\end{array}$ \\
\hline$[107]$ & $\begin{array}{l}\text { Regional } \\
\text { population } \\
\text { sample, } \\
\text { Northern } \\
\text { Sweden }\end{array}$ & Cohort & $\begin{array}{l}1071 \\
30-42 y\end{array}$ & $\begin{array}{l}\text { Individual-level indicators } \\
\text { Psychosocial job security }\end{array}$ & $\begin{array}{l}\text { Psychological } \\
\text { Well-being } \\
\text { Self-rated health, } \\
\text { sleep quality } \\
\text { and mental health }\end{array}$ & $\begin{array}{l}\text { The adverse effects of job } \\
\text { insecurity on health are } \\
\text { present on both permanent } \\
\text { and temporary employees. }\end{array}$ & $\begin{array}{l}\text { The study has a follow-up } \\
\text { design.Temporal order of } \\
\text { exposures affected all } \\
\text { participants at the same } \\
\text { time producing stronger } \\
\text { causal conclusions. }\end{array}$ & $\begin{array}{l}\text { The results and } \\
\text { recommendations should } \\
\text { not be generalized to } \\
\text { other cohorts. }\end{array}$ \\
\hline [108] & $\begin{array}{l}\text { Community } \\
\text { sample of } \\
\text { workers from } \\
\text { private } \\
\text { organization, } \\
\text { Italy }\end{array}$ & $\begin{array}{l}\text { Cross- } \\
\text { sectional }\end{array}$ & $\begin{array}{l}1236 \\
(2010-2011)\end{array}$ & $\begin{array}{l}\text { Individual-level indicators } \\
\text { Psychosocial job quality } \\
\text { and Security }\end{array}$ & $\begin{array}{l}\text { Psychological } \\
\text { Well-being } \\
\text { Mental health } \\
\text { distress (GHQ12) }\end{array}$ & $\begin{array}{l}\text { Job stress fully mediated } \\
\text { the relationship between } \\
\text { fear of the crisis and } \\
\text { mental health of the } \\
\text { workers. }\end{array}$ & $\begin{array}{l}\text { Large sample and uses a } \\
\text { well validated scale for } \\
\text { detection of mental } \\
\text { distress. }\end{array}$ & $\begin{array}{l}\text { Its cross-sectional design } \\
\text { removes the possibility of } \\
\text { causal inference.Possible } \\
\text { response bias since those } \\
\text { with mental distress may } \\
\text { perceive and rate the same } \\
\text { work environment more } \\
\text { stressful than those } \\
\text { without mental distress. }\end{array}$ \\
\hline [109] & $\begin{array}{l}\text { National } \\
\text { Population } \\
\text { sample, } \\
\text { England, UK }\end{array}$ & $\begin{array}{l}\text { Cross- } \\
\text { sectional }\end{array}$ & $\begin{array}{l}2603 \\
20-55 y\end{array}$ & $\begin{array}{l}\text { Individual-level indicators } \\
\text { Employment Status } \\
\text { Psychosocial job quality }\end{array}$ & $\begin{array}{l}\text { Common } \\
\text { Mental } \\
\text { Disorders } \\
\text { CIS-R interview: } \\
\text { Common Mental } \\
\text { Disorders (CMD) }\end{array}$ & $\begin{array}{l}\text { The prevalence of mental } \\
\text { disorders among unemployed } \\
\text { ( } 33.1 \% \text { ) was greater than in } \\
\text { employed }(12.9 \% \text {; OR } 3.34 \text {, } \\
95 \% \mathrm{Cl} 2.06-5.42, p<0.001) \text {. } \\
\text { Results were similar for those } \\
\text { respondents in the poorest } \\
\text { quality jobs. }\end{array}$ & $\begin{array}{l}\text { Uses a well validated scale } \\
\text { for detection of common } \\
\text { mental disorders. }\end{array}$ & $\begin{array}{l}\text { Its cross-sectional design } \\
\text { removes the possibility of } \\
\text { causal inference.Possible } \\
\text { response bias since those } \\
\text { with mental illnesses may } \\
\text { perceive and rate the same } \\
\text { work environment more } \\
\text { negatively than those } \\
\text { without a disorder. }\end{array}$ \\
\hline [110] & $\begin{array}{l}\text { National } \\
\text { working } \\
\text { population } \\
\text { sample, UK }\end{array}$ & $\begin{array}{l}\text { Cross- } \\
\text { sectional }\end{array}$ & $\begin{array}{l}3581 \\
(2007) \\
16-64 y\end{array}$ & $\begin{array}{l}\text { Individual-level indicators } \\
\text { Psychosocial job security } \\
\text { Indebtedness }\end{array}$ & $\begin{array}{l}\text { Common } \\
\text { Mental } \\
\text { Disorders } \\
\text { Depression }\end{array}$ & $\begin{array}{l}\text { Risk of depression is greater } \\
\text { for poor job security (OR }=1.58, \\
95 \% \text {, Cl:1.22-2.06). Adj for age } \\
\text { and sex, job insecurity (OR }=1.86 \text {, } \\
95 \% \text { Cl:1.47-2.35) and debt } \\
\text { (OR }=2.17,95 \% \text { Cl:1.58-2.98) } \\
\text { were independently associated. }\end{array}$ & $\begin{array}{l}\text { Large representative } \\
\text { sample. }\end{array}$ & $\begin{array}{l}\text { Its cross-sectional design } \\
\text { removes the possibility } \\
\text { of causal inference: job } \\
\text { insecurity may be more } \\
\text { frequently reported by } \\
\text { people rendered } \\
\text { pessimistic by a mood } \\
\text { disorder. }\end{array}$ \\
\hline
\end{tabular}


Table 5 Characteristics of studies included in review relating job quality and security, deprivation and socioeconomic status and mental health outcomes, 2004-2014

(Continued)

\begin{tabular}{|c|c|c|c|c|c|c|c|c|}
\hline [111] & $\begin{array}{l}\text { National } \\
\text { population } \\
\text { sample, USA }\end{array}$ & Cohort & $\begin{array}{l}34,653 \\
(2001-02 \\
04-05) \\
\geq 20 y\end{array}$ & $\begin{array}{l}\text { Individual-level indicators } \\
\text { Household income } \\
\text { Socioeconomic inequalities }\end{array}$ & $\begin{array}{l}\text { Common } \\
\text { Mental } \\
\text { Disorders } \\
\text { Substance } \\
\text { use disorders } \\
\text { (AUDADIS-IV) }\end{array}$ & $\begin{array}{l}\text { A decrease in household income } \\
\text { during the } 2 \text { time points was } \\
\text { associated with an increased } \\
\text { risk of incident mood, anxiety, } \\
\text { or substance use disorders } \\
\text { (adj } \mathrm{OR}=1.30 ; 99 \% \text { (l:1.06-1.60) }\end{array}$ & $\begin{array}{l}\text { Nationally representative } \\
\text { sample and strong } \\
\text { associations.Temporal } \\
\text { order of exposures } \\
\text { produces stronger causal } \\
\text { conclusions. }\end{array}$ & $\begin{array}{l}\text { Unable to adjust for } \\
\text { physical health conditions } \\
\text { that may be potential } \\
\text { confounders. }\end{array}$ \\
\hline [112] & $\begin{array}{l}\text { National } \\
\text { population } \\
\text { sample, New } \\
\text { Zealand }\end{array}$ & Cohort & $\begin{array}{l}15,340 \\
(2002-2004 / 05) \\
>25 y\end{array}$ & $\begin{array}{l}\text { Individual-level indicators } \\
\text { Total wealthSocioeconomic } \\
\text { inequalities }\end{array}$ & $\begin{array}{l}\text { Psychological } \\
\text { Well-being } \\
\text { Mental health } \\
\text { distress (Kessler-10) }\end{array}$ & $\begin{array}{l}\text { High psychological distress } \\
\text { linked to lowest wealth } \\
\text { quintile compared with } \\
\text { the highest (OR } 3.06,95 \% \mathrm{Cl} \\
2.68 \text { to } 3.50 \text { ). Adj for age and } \\
\text { sex did not alter the relationship; } \\
\text { adj for income and area } \\
\text { deprivation attenuated the OR } \\
\text { to } 1.73 \text { ( } 95 \% \mathrm{Cl} 1.48 \text { to } 2.04) \text {; } \\
\text { adj baseline health status } \\
\text { reduced the OR to } 1.45 \\
\text { (95\% Cl } 1.23 \text { to } 1.71 \text { ). }\end{array}$ & $\begin{array}{l}\text { Strong associations } \\
\text { between inequalities in } \\
\text { wealth and psychological } \\
\text { distress. Temporal order of } \\
\text { exposures and } \\
\text { confounders affected all } \\
\text { participants at the same } \\
\text { time producing stronger } \\
\text { causal conclusions. }\end{array}$ & $\begin{array}{l}\text { The socioeconomic } \\
\text { position at baseline was } \\
\text { not controlled.The results } \\
\text { and recommendations } \\
\text { should not be generalized } \\
\text { to other cohorts. }\end{array}$ \\
\hline [113] & $\begin{array}{l}\text { National } \\
\text { population } \\
\text { sample, } \\
\text { Britain, UK }\end{array}$ & Cohort & $\begin{array}{l}8185 \\
(1991) \\
(2003)\end{array}$ & $\begin{array}{l}\text { Individual-level indicators } \\
\text { Indebtednesshousing } \\
\text { payment problems }\end{array}$ & $\begin{array}{l}\text { Psychological } \\
\text { Well-being } \\
\text { Mental health } \\
\text { distress caseness } \\
\text { (GHQ-12) }\end{array}$ & $\begin{array}{l}\text { Housing payment problems } \\
\text { and debts have significant } \\
\text { detrimental effects on } \\
\text { mental Well-being. The } \\
\text { sizes of these effects are } \\
\text { in addition to and larger } \\
\text { in magnitude than those } \\
\text { associated with financial } \\
\text { hardship. }\end{array}$ & $\begin{array}{l}\text { Temporal order of } \\
\text { exposures, confounders, } \\
\text { and the outcome under } \\
\text { consideration affected all } \\
\text { participants at the same } \\
\text { time producing stronger } \\
\text { causal conclusions. }\end{array}$ & $\begin{array}{l}\text { Generalizing findings may } \\
\text { be reasonably limited to } \\
\text { the UK's welfare system in } \\
\text { regard to housing payment } \\
\text { problems. The results and } \\
\text { recommendations should } \\
\text { not be generalized to } \\
\text { other cohorts. }\end{array}$ \\
\hline [114] & $\begin{array}{l}\text { Community } \\
\text { sample, } \\
\text { Detroit, USA }\end{array}$ & Cohort & $\begin{array}{l}1547 \\
(2008) \\
(2010)\end{array}$ & $\begin{array}{l}\text { Individual-level indicators } \\
\text { Home foreclosure } \\
\text { Financial hardship }\end{array}$ & $\begin{array}{l}\text { Common } \\
\text { Mental } \\
\text { Disorders } \\
\text { Major depression } \\
\text { (PHQ-9) } \\
\text { Generalized } \\
\text { anxiety disorder } \\
\text { (GAD-7) }\end{array}$ & $\begin{array}{l}\text { Foreclosure was associated } \\
\text { with an increased rate of } \\
\text { major depression [incidence } \\
\text { density ratio (IDR) 2.4, } 95 \% \text {; } \\
\text { Cl:1.6-3.6] and GAD (IDR 1.9, } \\
95 \% \text {; Cl:1.4-2.6) }\end{array}$ & $\begin{array}{l}\text { Establishes longitudinal } \\
\text { associations between } \\
\text { home foreclosure and } \\
\text { common mental disorders } \\
\text { producing stronger causal } \\
\text { conclusions. }\end{array}$ & $\begin{array}{l}\text { The sample is limited to a } \\
\text { longitudinal cohort of } \\
\text { pre-dominantly African- } \\
\text { American adults.Because } \\
\text { mental health problems } \\
\text { are common among } \\
\text { individuals at risk of } \\
\text { foreclosure, the observed } \\
\text { associations may result, } \\
\text { in part, from pre-existing } \\
\text { psychopathology. }\end{array}$ \\
\hline [115] & $\begin{array}{l}\text { Community } \\
\text { sample, } \\
\text { Wales, UK }\end{array}$ & $\begin{array}{l}\text { Cross- } \\
\text { sectional }\end{array}$ & $\begin{array}{l}88,623 \\
(2003 / 04-2010) \\
18-74 y\end{array}$ & $\begin{array}{l}\text { Individual-level indicators } \\
\text { Area income deprivation } \\
\text { Socioeconomic inequalities }\end{array}$ & $\begin{array}{l}\text { Psychological } \\
\text { Well-being } \\
\text { Mental health } \\
\text { distress (MHI-5) }\end{array}$ & $\begin{array}{l}\text { High neighbourhood income } \\
\text { inequality was associated with } \\
\text { better mental health in } \\
\text { low-deprivation neighbourhoods } \\
(P=0.036) \text {. Income inequality } \\
\text { at regional level was significantly }\end{array}$ & $\begin{array}{l}\text { Uses a continuous } \\
\text { measure of mental health } \\
\text { symptoms.Large sampling } \\
\text { fraction. }\end{array}$ & $\begin{array}{l}\text { No data were available } \\
\text { on individual income.lts } \\
\text { cross-sectional design } \\
\text { removes the possibility } \\
\text { of causal inference. }\end{array}$ \\
\hline
\end{tabular}


Table 5 Characteristics of studies included in review relating job quality and security, deprivation and socioeconomic status and mental health outcomes, 2004-2014 (Continued)

\begin{tabular}{|c|c|c|c|c|c|c|c|c|}
\hline [116] & $\begin{array}{l}\text { Community } \\
\text { sample, } \\
\text { France }\end{array}$ & Cohort & $\begin{array}{l}1103 \\
(1991-2009) \\
22-35 y\end{array}$ & $\begin{array}{l}\text { Individual-level indicators } \\
\text { Socioeconomic status } \\
\text { Level of education }\end{array}$ & $\begin{array}{l}\text { Substance- } \\
\text { Disorders } \\
\text { tobacco, } \\
\text { cannabis use, } \\
\text { other illegal } \\
\text { drug use }\end{array}$ & $\begin{array}{l}\text { Low socioeconomic status was } \\
\text { linked with higher rates of tobacco } \\
\text { smoking }[\mathrm{OR}=2.11,95 \% \mathrm{Cl} 1.51-2.96] \text {, } \\
\text { cannabis use }[\mathrm{OR}=1.75,95 \% 1.20-2.55] \text {, } \\
\text { problematic cannabis use [OR }=2.44 \text {, } \\
95 \% \mathrm{Cl} 1.38-4.30] \text { and other illegal } \\
\text { drugs }[\mathrm{OR}=2.27,95 \% \mathrm{Cl} 1.11-4.65] \text {. }\end{array}$ & $\begin{array}{l}\text { Relatively large community } \\
\text { sample of young adults. } \\
\text { Longitudinal measures of } \\
\text { family and juvenile } \\
\text { characteristics obtained } \\
\text { independently of } \\
\text { participants' reports of } \\
\text { substance-use }\end{array}$ & $\begin{array}{l}\text { The research focused } \\
\text { only young adults whose } \\
\text { parents worked in a large } \\
\text { national company and } \\
\text { were part of an ongoing } \\
\text { epidemiological study. } \\
\text { Other variables that can } \\
\text { act as confounders were } \\
\text { not controlled: family and } \\
\text { peer characteristics. }\end{array}$ \\
\hline [117] & $\begin{array}{l}\text { National } \\
\text { population } \\
\text { sample, } \\
\text { England, UK }\end{array}$ & $\begin{array}{l}\text { Cross- } \\
\text { sectional }\end{array}$ & $\begin{array}{l}7461 \\
(2007) \\
35-54 y\end{array}$ & $\begin{array}{l}\text { Individual-level indicators } \\
\text { Indebtedness }\end{array}$ & $\begin{array}{l}\text { Suicidal } \\
\text { Behaviours } \\
\text { Suicidal ideation }\end{array}$ & $\begin{array}{l}\text { Those in debt were twice as likely } \\
\text { to think about suicide after } \\
\text { controlling for socio-demographic, } \\
\text { economic and lifestyle } \\
\text { factors. }\end{array}$ & $\begin{array}{l}\text { Representative } \\
\text { sample.Strong association } \\
\text { between suicidal thoughts } \\
\text { and being in debt. }\end{array}$ & $\begin{array}{l}\text { No causal inference can } \\
\text { be made due to the } \\
\text { cross-sectional nature } \\
\text { of the study. }\end{array}$ \\
\hline
\end{tabular}


Table 6 Characteristics of studies included in review focusing children and adolescents, older adults and people with mental health problems, 2004-2014

\begin{tabular}{|c|c|c|c|c|c|c|c|c|}
\hline Study & Setting & $\begin{array}{l}\text { Study } \\
\text { design }\end{array}$ & $\begin{array}{l}N \\
\text { Year } \\
\text { Age }\end{array}$ & $\begin{array}{l}\text { Socioeconomic } \\
\text { determinants }\end{array}$ & Mental health outcomes & Associations/Effects & Strengths & Limitations \\
\hline [118] & $\begin{array}{l}\text { Regional sample of } \\
\text { parents and } \\
\text { children, Southern } \\
\text { Finland }\end{array}$ & Cohort & $\begin{array}{l}114912 \text { y } \\
843 \text { mothers } \\
30-59 y \\
573 \text { fathers } \\
28-66 \text { y }\end{array}$ & $\begin{array}{l}\text { Individual-level } \\
\text { indicators } \\
\text { Family perceived } \\
\text { financial strain }\end{array}$ & $\begin{array}{l}\text { Psychological Well-being } \\
\text { Parental Mental health } \\
\text { distress caseness (GHQ-12) } \\
\text { Child mental health }\end{array}$ & $\begin{array}{l}\text { Family economic hardship } \\
\text { creates a risk for child } \\
\text { mental health through } \\
\text { economic pressures and } \\
\text { problems in parental } \\
\text { mental health, marital } \\
\text { interaction, and parenting } \\
\text { even in a welfare state. }\end{array}$ & $\begin{array}{l}\text { Gives information } \\
\text { on } \\
\text { transgenerational } \\
\text { effect of family } \\
\text { economic pressure } \\
\text { on child mental } \\
\text { health.Child mental } \\
\text { health was } \\
\text { reported by both } \\
\text { parents and } \\
\text { children, which } \\
\text { adds to the } \\
\text { reliability.Temporal } \\
\text { order of exposures, } \\
\text { confounders, and } \\
\text { the outcome } \\
\text { under } \\
\text { consideration } \\
\text { affected all } \\
\text { participants at the } \\
\text { same time } \\
\text { producing stronger } \\
\text { causal conclusions }\end{array}$ & $\begin{array}{l}\text { Reporter bias is expected since } \\
\text { mothers and fathers reported on } \\
\text { their own mental health and } \\
\text { parenting.Other contexts } \\
\text { determinants such as reductions } \\
\text { in funding in day care and } \\
\text { schools can act as confounders. } \\
\text { Generalizing findings is limited } \\
\text { to the uniqueness of the Finish } \\
\text { welfare system with extensive } \\
\text { governmental support to families }\end{array}$ \\
\hline [119] & $\begin{array}{l}\text { Cross-national } \\
\text { samples of } \\
\text { adolescents, } 31 \\
\text { countries } \\
\text { worldwide }\end{array}$ & $\begin{array}{l}\text { Repeated } \\
\text { cross- } \\
\text { sectional }\end{array}$ & $\begin{array}{l}164,623 \\
(2005-2006) \\
168,284 \\
(2009-2010) \\
11-15 y\end{array}$ & $\begin{array}{l}\text { Inter-time Variables } \\
\text { Macroeconomic } \\
\text { indicators } \\
\text { Unemployment Rates }\end{array}$ & $\begin{array}{l}\text { Psychological Well-being } \\
\text { Psychological health complaints } \\
\text { (HBSC symptom checklist) }\end{array}$ & $\begin{array}{l}\text { Ireland and Portugal were } \\
\text { the only countries facing a } \\
\text { rise In psychological health } \\
\text { complaints }(9-17 \%) \text { with } \\
\text { increasing unemployment } \\
(21-148 \%) \text {.Youth } \\
\text { unemployment rates in } \\
2010 \text { increased the } \\
\text { likelihood of psychological } \\
\text { health complaints. }\end{array}$ & $\begin{array}{l}\text { Uses nationally } \\
\text { representative data } \\
\text { on adolescents } \\
\text { from } 31 \text { countries, } \\
\text { surveyed over two } \\
\text { time points, before } \\
\text { and after recession }\end{array}$ & $\begin{array}{l}\text { Data derives from 2006-2010 } \\
\text { and the crisis started in } 2008 \\
\text { so the long term effects of } \\
\text { the recession could not be } \\
\text { investigated. The sample is } \\
\text { composed only by } \\
\text { adolescents aging } 11 \text { to } \\
15 \text { years old. }\end{array}$ \\
\hline [120] & $\begin{array}{l}\text { National population } \\
\text { sample of } \\
\text { adolescent,Slovenia }\end{array}$ & $\begin{array}{l}\text { Cross- } \\
\text { sectional }\end{array}$ & $\begin{array}{l}1815 \\
(2010) \\
15 y\end{array}$ & $\begin{array}{l}\text { Individual-level } \\
\text { indicators } \\
\text { Family Affluence } \\
\text { Scale, perceived } \\
\text { material welfare, } \\
\text { family type, } \\
\text { occupational } \\
\text { status of parents }\end{array}$ & $\begin{array}{l}\text { Psychological Well-being } \\
\text { Mental health (KIDSCREEN-10, } \\
\text { SDQ), Life satisfaction Feelings } \\
\text { of depression }\end{array}$ & $\begin{array}{l}\text { The adolescents who } \\
\text { perceived to be } \\
\text { socioeconomically worse } \\
\text { off had 4-times higher } \\
\text { odds ( } p<0.001) \text { of a low } \\
\text { life satisfaction, a greater } \\
\text { chance of a low quality } \\
\text { of life, and a higher SDQ } \\
\text { score than those who } \\
\text { perceived to be better } \\
\text { off }(p<0.001) \text {. }\end{array}$ & $\begin{array}{l}\text { Uses a national } \\
\text { representative } \\
\text { sample and several } \\
\text { variables to } \\
\text { measure } \\
\text { socioeconomic } \\
\text { status. }\end{array}$ & $\begin{array}{l}\text { Includes only } 15 \text {-year-olds } \\
\text { who are enrolled in school } \\
\text { and does not include } \\
\text { dropouts, who might be } \\
\text { among the most socioeconomically } \\
\text { underprivileged.lts cross-sectional } \\
\text { design removes the possibility of } \\
\text { causal inference. }\end{array}$ \\
\hline
\end{tabular}


Table 6 Characteristics of studies included in review focusing children and adolescents, older adults and people with mental health problems, 2004-2014 (Continued)

[123] Regional sample of Cross- 2836 adolescents, Kosice, sectional 14-22 Slovakia ndividual-level Psychological Well-being indicators Self-rated healthLong-term Parental employment well-beingHealth complaints status
[124] Regional sample of Cohort adolescents,

emergency room

Ontario, Canada

[125] National population sample of adolescent,USA

\section{Repeated \\ cross-}

15,739

(2002-2011)

$12-17$ y

Pre and Post- recession

period

Suicidal behaviours

Hospital records of

suicide-related

behaviours

Suicidal Behaviours

Suicide ideation,

attempts and plans
Macroeconomic

State level job loss
Having at least one

parent unemployed

has a statistical significant negative impact on

erceptions of adolescent health.

Children in families with one or both parents without paid work had an increased prevalence of recurrent psychosomatic symptoms $(\mathrm{OR}=1.52$ to 3.20)

Parental long-term unemployment (especially of fathers) is negatively associated with adolescents subjective health. Father's long-term unemployment was a significant predictor of moderate self-rated health and low long-term well-being among girls and boys. Mother's long-term unemployment was

negatively associated with self-rated health of girlss and long-standing illness among boys.

The suicide-related behaviours incidence rates decreased by $30 \%$ in boys and girls from FYs 2002/03 to 2006/07, but stopped afterwards and subsequent admissions increased.

State level unemployment during the year preceding the survey increased girls' probability of suicidal ideation and suicide plans, ideation and suicide but did not affect the suicide-related behaviors of boys information about removes the possibility of causal

inference The study was not de-

ransgenerational signed specifically to address

effect of causal links between the vari-

employment

ables and parental employment.

Gives important information about the

transgenerational effect of

employment

status.

Gives important

information about

transgenerational

effect of

employmen

status.

Underreporting bias is expected as children differ in their tendency to report symptoms to their parents. Also the parents' reports on their children can depend on their own health. Its cross-sectional design removes

the possibility of causal inference.

Lack of specific detailed

informationabout parental unemployment (maternity leave of mothers, retirement, orinvalidity of parents were considered unemployment)

Large sample of adolescents and examines trends the total suicide related behaviour during recession periods.

Uses a national representative sample andGives important

information circumstances

effects on

adolescents risk

behaviours.
The hospital records do not identify suicidal intent. Data is not representative of the genera population. Suicide-related behaviours are complex and other variables may act as confounders.

It is unable to identify the pathways through which panemployment rates affect adolescents' suiciderelated behaviors. 
Table 6 Characteristics of studies included in review focusing children and adolescents, older adults and people with mental health problems, 2004-2014 (Continued)

\begin{tabular}{|c|c|c|c|c|c|c|c|c|}
\hline [126] & $\begin{array}{l}\text { Regional sample of } \\
\text { older adults, } \\
\text { Canberra/ } \\
\text { Queanbeyan, } \\
\text { Australia }\end{array}$ & Cohort & $\begin{array}{l}1973 \\
(2005-2010) \\
\text { mean age } \\
66.58 \text { y } \\
(S D=1.5)\end{array}$ & $\begin{array}{l}\text { Inter-time Variables } \\
\text { Individual-level } \\
\text { indicators } \\
\text { Pre and Post- recession } \\
\text { periodFinancial security } \\
\text { Financial hardship }\end{array}$ & $\begin{array}{l}\text { Common Mental } \\
\text { Disorders } \\
\text { DepressionAnxiety } \\
\text { (Goldberg Scales) } \\
\text { Self-reported health }\end{array}$ & $\begin{array}{l}\text { Economic slowdown } \\
\text { related distress is linked } \\
\text { to greater depression } \\
\text { symptoms at both waves } \\
2(\mathrm{t}(655)=-3.44, p=.001) \\
\text { and } 3(\mathrm{t}(662)=-4.96, \\
p<.001) \text {, and greater } \\
\text { anxiety symptoms at } \\
\text { both waves (wave } \\
2-\mathrm{t}(655)=-3.62, p<.001 ; \\
\text { wave } 3-\mathrm{t}(662)=-5.15 \text {, } \\
p<.001) \text {. }\end{array}$ & $\begin{array}{l}\text { Temporal order of } \\
\text { exposures, } \\
\text { confounders, and } \\
\text { the outcome } \\
\text { under } \\
\text { consideration } \\
\text { affected all } \\
\text { participants at the } \\
\text { same time } \\
\text { producing stronger } \\
\text { causal conclusions. }\end{array}$ & $\begin{array}{l}\text { The analysis was restricted to } \\
\text { older adults at baseline. } \\
\text { Consequently, the results and } \\
\text { recommendations should not be } \\
\text { applied to younger } \\
\text { cohorts.Limited period of time, } \\
\text { the long term effects of the } \\
\text { recession could not be } \\
\text { investigated. }\end{array}$ \\
\hline [127] & $\begin{array}{l}\text { National population } \\
\text { sample of older } \\
\text { adults, USA }\end{array}$ & Cohort & $\begin{array}{l}2261 \\
(2005-2006) \\
(2010-2011) \\
>57 y\end{array}$ & $\begin{array}{l}\text { Individual-level } \\
\text { indicators } \\
\text { Home foreclosure }\end{array}$ & $\begin{array}{l}\text { Common Mental } \\
\text { Disorders } \\
\text { Depressive } \\
\text { symptoms } \\
\text { (CES-D) }\end{array}$ & $\begin{array}{l}\text { Increases in neighborhood- } \\
\text { level foreclosure was } \\
\text { associated with an } \\
\text { increased rate in } \\
\text { depression in older adults. } \\
\text { Notices of default }(\mathrm{OR}= \\
1.75 ; 95 \% \mathrm{Cl}=1.14,2.67) \\
\text { and properties returning } \\
\text { to ownership by the bank } \\
(\mathrm{OR}=1.62 ; 95 \% \mathrm{Cl}=1.06 \\
2.47) \text { were associated with } \\
\text { depressive symptoms. }\end{array}$ & $\begin{array}{l}\text { Establishes } \\
\text { longitudinal } \\
\text { associations } \\
\text { between home } \\
\text { foreclosure and } \\
\text { depressive } \\
\text { symptoms } \\
\text { producing stronger } \\
\text { causal conclusions. }\end{array}$ & $\begin{array}{l}\text { The mechanisms linking } \\
\text { increases in foreclosure to } \\
\text { depressive symptoms are not } \\
\text { explored.The sample is limited to } \\
\text { a longitudinal cohort of older } \\
\text { American adults. }\end{array}$ \\
\hline [128] & $\begin{array}{l}\text { Cross-national } \\
\text { working population } \\
\text { sample, European } \\
\text { Union countries }\end{array}$ & $\begin{array}{l}\text { Cross- }^{-} \\
\text {sectional }\end{array}$ & $\begin{array}{l}20,368(2006) \\
20,124(2010) \\
18-64 \text { y }\end{array}$ & $\begin{array}{l}\text { Inter-time Variables } \\
\text { Macroeconomic } \\
\text { indicators } \\
\text { ndividual-level } \\
\text { indicators } \\
\text { Pre and Post- } \\
\text { recession } \\
\text { periodEmployment } \\
\text { StatusSate level } \\
\text { unemployment }\end{array}$ & $\begin{array}{l}\text { Psychological } \\
\text { Well-being } \\
\text { Mental health } \\
\text { distress (MHI-5) } \\
\text { Mental health } \\
\text { disorders }\end{array}$ & $\begin{array}{l}\text { Following the onset of the } \\
\text { recession, individuals with } \\
\text { mental health problems } \\
\text { were more vulnerable to } \\
\text { losing their jobs [OR }=1.12 \text {, } \\
95 \% \mathrm{Cl}: 1.03-1.344 \text { (OR: } \\
1.12,95 \% \mathrm{Cl}: 1.03,1.34)\end{array}$ & $\begin{array}{l}\text { Uses nationally } \\
\text { representative data } \\
\text { on people with } \\
\text { and without } \\
\text { mental health } \\
\text { problems from } 27 \\
\text { countries in Europe } \\
\text { surveyed over two } \\
\text { time points, before } \\
\text { and after recession. }\end{array}$ & $\begin{array}{l}\text { The data was collected through } \\
\text { brief, self-reported questionnaire- } \\
\text { s.Limited period of time, the long } \\
\text { term effects of the recession } \\
\text { could not be investigated.lts } \\
\text { cross-sectional design removes } \\
\text { the possibility of causal inference. }\end{array}$ \\
\hline
\end{tabular}


sectional analysis before and after the onset of the crisis revealed that state-level unemployment during the year preceding the survey increased girls' rates of suicidal ideation and suicide plans, but did not affect the suicidal behaviour of boys [125].

Studies focusing on older adults report that those facing distress related to economic slowdown and rates of home foreclosure also had greater depression and anxiety symptoms in Australian cohort studies [126, 127].

\section{People with mental health problems}

A cross-sectional study comparing data from $27 \mathrm{EU}$ countries before and after the crisis found that individuals with mental health problems were more vulnerable to losing their employment than those without these problems. This evidence is particularly important for people already facing mental health problems because it may indicate that during a recession discriminatory attitudes towards people with chronic mental health conditions may harden, both in the job market and in society, further increasing their suffering and isolation [128].

\section{Discussion}

In general, evidence on the impact of economic crises and recessions on mental health is accruing, but comprehensive studies are lacking. Epidemiological data comparing changes in health status before and after a recession are consistent and report negative associations with mental health and increased mental health problems. However, to measure the extension and duration of these impacts and to isolate the exact causal factors appeared to be challenging. There is a preponderance of cross-sectional and ecological studies compared to cohort or case-control studies. This causes great limitations in terms of determining causality between the recession and mental health problems. Nevertheless, the repeated cross-sectional studies helped to better estimate the changes in the population's outcomes before and after the recession period.

In terms of geographical allocation, most of the research is being done in Europe and North America during the period of this review (2004-2014). Some of the countries hardest hit by the economic recession (Greece, Spain, and Italy) are monitoring changes in the mental health outcomes of their populations, although they are doing so mainly by using repeated cross-sectional surveys or ecological analysis. We found no specific studies from Ireland or Portugal focusing on the effects of the recession on mental health. We strongly believe that research results from these countries could contribute to a better understanding of the consequences of the recession since its impact on mental health varies greatly, depending on how austerity measures and policy responses were implemented. Additionally, there were a very limited number of studies from low and middle-income countries despite the fact that there are strong reasons to believe that these countries are likely to be heavily affected by the recession, especially because any further reductions in these countries' already weak health budgets (mental health services in particular) is likely to be very damaging. We argue that research from these countries finds substantial barriers to publication in widely accessible journals due to possibly material and financial constraints, problems of research design and statistics and thinkable difficulty in writing in English. Thus, we argue that this under-representation of research might result in limited conclusions.

Nonetheless, the studies included in this review confirm that recession periods are feasibly associated with the increased prevalence of psychological distress and common mental disorders, substance disorders, and ultimately suicidal behaviour. Despite being limited to the validity of self-reporting, the data on alcohol misuse behaviour indicates that any increase in its prevalence may be countercyclical and related to unemployment rates. We further add that recessions might result in an increased prevalence of smoking and illicit substance use since the literature indicated this may be a coping mechanism used to help deal with unemployment and economic distress [100]. However, the impact may vary according to the profile of substance users. Recreational users may be more susceptible to cuts in income, therefore reducing abuse, while others who are more dependent may actually adopt riskier patterns of substance misuse, such as injecting or binge drinking, in order to maximise the effects of the substances they have managed to purchase [129]. Further analysis of these fields is still required.

Although reports of growing suicidal ideation and attempts in countries in recession are limited to the complexity of the phenomenon, to the cultural background, and to the quality of the data sets and self-reports, which are susceptible to recall bias, it is consistent with the previous idea that suicide is more common in areas of high socioeconomic deprivation, social fragmentation, and unemployment [4]. Futhermore, a great proportion of the evidence from this review shows that unemployment, precarious work, debt, and financial deprivation are significantly associated with mental health problems. Determinants as such are well-known driving forces for widening health inequities, and put some groups of people at higher risk of suffering the impact of the economic recession. The influence of these factors on mental health has been widely recognised in the past $[15,130,131]$. Therefore, special attention should be given to people facing economic pressure and unemployment.

Indirect data supports the view that families and children may be disproportionally affected by recession, which is consistent with the Family Stress Model [19, 20]. Many mental disorders often start in adolescence or young adulthood. Growing up in a challenging environment can put 
young people in a very vulnerable position [132-134]. Upto-date evidence shows that $27 \%$ of young Europeans aged below 18 are at risk of poverty or social exclusion and, considering the growing number of people who are unemployed and in deprivation, these are worrying indicators [135]. Failing to protect the mental health of young people and to capitalise on their energy may indicate that we will possibly face a long-lasting loss of future adult productivity $[134,136]$. Unexpectedly, there is a substantial research gap on the effects of recession on families and children. A better understanding of these effects could be gained from research focusing on how job losses and economic strain affect family members.

\section{Research and policy implications}

Summarising the data from this review gives us a global perspective and allows some hypotheses to emerge that serve as a framework for future research on economic recessions and mental health outcomes:

- it is plausible that the actual recession increased the population's psychological distress;

- according to the evidence reviewed, periods of recession correlate with higher prevalence of common mental disorders, substance disorders, and ultimately suicidal behaviour;

- it may be possible that in order to cope with psychosocial stress people might turn to substance misuse;

- some key factor seem to make people more vulnerable to the effects of the recession: being unemployed, having a precarious work situation, facing debts and economic strain, and having a pre-existing mental illness;

- economic recession may also have a severe and long-term impact on mental health in children and young people, especially if they face stress within the family as a result of economic hardship or parental unemployment;

- some specific differences between countries and regions were found in this review. The authors hypothesise that this may be explained by the socioeconomic response policy to recession (the presence of unemployment benefits or social programmes) which could influence changes in the mental health outcomes of the populations;

- more research is needed concerning mediating factors between the determinants of a recession and mental health outcomes;

- more research from countries badly hit by the economic recession and from low and middle income countries is needed;

- the links between recession and direct effects on health seem to be very complex, and the lagged effects have not been systematically studied because of a lack of longitudinal studies and therefore a scarcity of long data series persists.

Even though the economy can shape populations' mental wellbeing, better mental health can in turn be a major contributor to economic growth [136]. Policies and costeffective measures may affect the extent of the risk factors faced by populations and the occurrence of mental health disorders during and after an economic recession. The World Health Organisation [4] has argued that the mental health effects of economic crises depend on action in five key areas:

- active labour market programmes

- family support programmes

- regulation of the marketing of alcoholic beverages, restrictions on their availability, and taxation

- provision of quality and equitable access to primary care for those people at high risk of mental health problems

- debt relief programmes.

\section{Strengths and weaknesses of this study}

A language bias might be present since the review was exclusively based on English and Portuguese language research reports. Nonetheless, the potential impact of studies published in other languages in this literature review may be minimal since most of the publications in widely accessible journals are in English.

Another limitation may be the literature search time framed to last 10 years. Although it is an usual procedure [137], it could have limited the inclusion of other important works. Also, given the heterogeneity of the metrics used by the studies we were unable to use quantitative meta-analytic methods and therefore were not capable of identifying statistical patterns.

As included studies have mainly cross-sectional or ecological design, there is a limited space for establishing causal inferences. This is especially important because this gives only evidence of the rough short-term mental health outcomes related to economic recession and specific socioeconomic indicators, but there is still a lack of evidence on the longer-term consequences, particularly if the number of long-term unemployed people continues to grow and social safety nets experience further cuts.

Moreover, despite the fact that most studies are showing negative associations between the recession and levels of mental health, there may be mixed patterns (positive and negative effects of the recession) that are dependent on countries' policies and responses adopted to deal with the recession [14]. Thus, the generalisability of the findings is considerably limited by the uniqueness of the welfare and health systems of each country and its response measures 
to the economic recession itself. The only way to ascertain whether the economic recession has increased the incidence of poor mental health is to intensify the gathering of empirical evidence from long-term cohort studies [138].

Notwithstanding limitations, the literature review gives a rough approximation of the consequences of the recession, showing an increasing number of people experiencing poor mental health and reporting common mental disorders such as depression and anxiety, substancerelated disorders, and suicidal behaviour, which corroborates with what was found in other reference works [1-3].

\section{Conclusions}

Quality evidence showing that economic recessions are possibly associated with negative mental health outcomes of populations is growing. This seems especially true for psychological wellbeing, common mental disorders, substance disorders, and suicidal behaviour, despite the fact that the mediation pathways are still undisclosed. There are groups of people that may be especially vulnerable to the effects of recessions: the unemployed, those in debt or facing financial difficulties, people with pre-existing mental health problems, and families with children. It is well known that mental disorders and substance use disorders make major contributions to the global burden of disease in high-income countries and constitute important public health problems. Since economic downturns may possibly exacerbate mental ill-health and suicide risk factors, it is a collective responsibility to take action and reduce these unbearable costs as far as possible. In times of economic constraints countries may want to consider balancing appropriate resources. Structural reforms and the implementation of available cost-effective measures to achieve health and high levels of wellbeing may contribute to a more productive economy and desirable societal assets.

\section{Ethical approval}

None sought.

\section{Abbreviations}

MeSH: medical subject headings; GDP: gross domestic product.

\section{Competing interests}

None of the authors reported any further financial interests or potential conflicts of interest.

\section{Authors' contributions}

DF, MG and TG conceived the study. DF and CS developed the search strategy, read the papers, extracted data, and drafted the article. DF, MG and TG screened citations against inclusion/exclusion criteria. FS, DG, CS JC provided critical comments. All authors read and approved the final manuscript.

\section{Acknowledgments}

Frasquilho D. receives a grant from the Portuguese Foundation for Science and Technology (FCT), reference SFRH/BD/80846/2011.

This paper was also supported by the ECOP project "Support for creating excellent research teams and intersectoral mobility at Palacký University in Olomouc" (reg. no. CZ.1.07/2.3.00/30.0004), and by the Czech Ministry of
Education, Youth and Sport under contract no. LG 14043 and LG 14042. The authors wish to thank Dr. Sharon Leahy from the University of St. Andrews who assisted in the proof-reading of the manuscript.

\section{Author details}

${ }^{1}$ Medical School, CMDT, Nova University Lisbon, Lisbon, Portugal. ${ }^{2}$ Faculty of Human Kinetics, ISAMB, University of Lisbon, Lisbon, Portugal. Institute of Active Lifestyle, Faculty of Physical Culture, Palacky University Olomouc, Olomouc, Czech Republic. ${ }^{4}$ Psychiatry Department, Faculty of Medicine, University of Lisbon, Lisbon, Portugal. ${ }^{5}$ European Monitoring Centre for Drugs and Drug Addiction, Lisbon, Portugal. ${ }^{6}$ Aventura Social/ISAMB, University of Lisbon and Lisbon Lusíada University, Lisbon, Portugal. ${ }^{7}$ Department of Mental Health, Medical School, Nova University Lisbon, Lisbon, Portugal.

Received: 13 May 2015 Accepted: 11 January 2016

Published online: 03 February 2016

\section{References}

1. Zivin K, Paczkowski M, Galea S. Economic downturns and population mental health: research findings, gaps, challenges and priorities. Psychol Med. 2011:41(7):1343-8. doi:10.1017/S003329171000173X.

2. Karanikolos M, Mladovsky P, Cylus J, Thomson S, Basu S, Stuckler D, et al. Financial crisis, austerity, and health in Europe. Lancet. 2013: 381(9874):1323-31. doi:10.1016/S0140-6736(13)60102-6.

3. Modrek S, Stuckler D, McKee M, Cullen MR, Basu S. A review of health consequences of recessions internationally and a synthesis of the US response during the great recession. Public Health Rev. 2013;35:1.

4. WHO. Impact of economic crises on mental health. Geneva: The Regional Office for Europe of the World Health Organization; 2011.

5. Marmot M, Allen J, Bell R, Bloomer E, Goldblatt P. WHO European review of social determinants of health and the health divide. Lancet. 2012;380(9846): 1011-29. http://dx.doi.org/10.1016/S0140-6736(12)61228-8.

6. Eurofound. Eurofound year book 2012: living and working in Europe. Dublin, Ireland: Eurofound: 2013.

7. Eurostat. Unemployment rate, monthly average, by sex and age groups (\%). In: une_rt_m, ed.: Eurostat, 2013. Available from: http://appsso.eurostat.ec. europa.eu/nui/show.do?dataset=une_rt_m\&lang=en

8. European Comission. Flash Eurobarometer 338 - monitoring the social impact of the crisis: public perceptions in the European Union (WAVE 6), 2013. GESIS Data Archive: Cologne. 2013 Report No.ZA5773. doi:10.4232/1.11582

9. ILO. World of work report 2012 'better jobs for a better economy'. Geneva: International Labour Office; 2012

10. WHO. Poverty, social exclusion and health systems in the WHO European Region. Copenhagen. 2010.

11. Wilkinson RG, Marmot MG. Social determinants of health: the solid facts. Euro nonserial publication: World Health Organization, Regional Office for Europe. 2003.

12. Bambra C, Gibson M, Sowden A, Wright K, Whitehead M, Petticrew M. Tackling the wider social determinants of health and health inequalities: evidence from systematic reviews. J Epidemiol Community Health. 2010;64(4):284-91. doi:10. 1136/jech.2008.082743.

13. Alonso J, Angermeyer MC, Lépine JP. The European Study of the Epidemiology of Mental Disorders (ESEMeD) project: an epidemiological basis for informing mental health policies in Europe. Acta Psychiatr Scand. 2004;109:5-7. doi:10.1111/j.1600-0047.2004.00325.x.

14. Catalano R. Health, medical care, and economic crisis. N Engl J Med. 2009; 360(8):749-51. doi:10.1056/NEJMp0809122.

15. Warr PB. Work, unemployment, and mental health. New York: Oxford University Press; 1987.

16. Jahoda M. Employment and unemployment: a social-psychology analysis. Gambridge: Cambridge University Press; 1982.

17. Selenko E, Batinic B, Paul K. Does latent deprivation lead to psychological distress? Investigating Jahoda's model in a four-wave study. J Occup Organ Psychol. 2011;84(4):723-40.

18. Creed PA, Klisch J. Future outlook and financial strain: testing the personal agency and latent deprivation models of unemployment and well-being. J Occup Health Psychol. 2005;10(3):251-60. doi:10.1037/1076-8998.10.3.251.

19. Conger $K$, Rueter $M$, Conger $R$. The role of economic pressure in the lives of parents and their adolescents: the family stress model. In: 
Crockett L, Silbereisen R, editors. Negotiating adolescence in times of social change. New York: Cambridge University Press; 2000. p. 201-23.

20. Conger RD, Conger KJ. A family process model of economic hardship and adjustment of early adolescent boys. Child Dev. 1992;63(3):526. doi:10.1111/1467-8624.ep9207061028.

21. Kentikelenis A, Karanikolos M, Papanicolas I, Basu S, McKee M, Stuckler D. Health effects of financial crisis: Omens of a Greek tragedy. Lancet. 2011; 378(9801):1457-8. doi:10.1016/s0140-6736(11)61556-0.

22. Henkel D. Unemployment and substance use: a review of the literature (1990-2010). Curr Drug Abuse Rev. 2011;4(1):4-27.

23. Claessens S, Kose MA, Terrones ME. What happens during recessions, crunches and busts? Econ Policy. 2009;24(60):653-700.

24. Lynch J, Kaplan G. Socioeconomic position. Social epidemiology. 2000. p. 1.

25. Cavanagh JTO, Carson AJ, Sharpe M, Lawrie SM. Psychological autopsy studies of suicide: a systematic review. Psychol Med. 2003;33(03):395-405.

26. Bretteville-Jensen AL. Illegal drug use and the economic recession-what can we learn from the existing research? Int J Drug Policy. 2011;22(5):353-9. doi:10.1016/j.drugpo.2011.03.009.

27. Carlson MDA, Morrison RS. Study design, precision, and validity in observational studies. J Palliat Med. 2009;12(1):77-82. doi:10.1089/jpm.2008.9690.

28. Drydakis $\mathrm{N}$. The effect of unemployment on self-reported health and mental health in Greece from 2008 to 2013: a longitudinal study before and during the financial crisis. Soc Sci Med. 2014;128c:43-51. doi:10.1016/.jocscimed.2014.12.025.

29. Minelli L, Pigini C, Chiavarini M, Bartolucci F. Employment status and perceived health condition: longitudinal data from Italy. BMC Public Health. 2014;14(1):946. doi:10.1186/1471-2458-14-946.

30. Zavras D, Tsiantou V, Pavi E, Mylona K, Kyriopoulos J. Impact of economic crisis and other demographic and socio-economic factors on self-rated health in Greece. Eur J Public Health. 2013;23(2):206-10. doi:10.1093/eurpub/ cks143.

31. Vandoros $S$, Hessel $P$, Leone $T$, Avendano M. Have health trends worsened in Greece as a result of the financial crisis? A quasi-experimental approach Eur J Public Health. 2013;23(5):727-31. doi:10.1093/eurpub/ckt020.

32. Katikireddi SV, Niedzwiedz CL, Popham F. Trends in population mental health before and after the 2008 recession: a repeat cross-sectional analysis of the 1991-2010 Health Surveys of England. BMJ Open. 2012; 2(5):e001790. doi:10.1136/bmjopen-2012-001790.

33. Bartoll X, Palencia L, Malmusi D, et al. The evolution of mental health in Spain during the economic crisis. Eur J Public Health. 2014;24(3):415-8. doi:10.1093/ eurpub/ckt208.

34. Blomqvist $\mathrm{S}$, Burstrom B, Backhans MC. Increasing health inequalities between women in and out of work-the impact of recession or policy change? A repeated cross-sectional study in Stockholm county, 2006 and 2010. Int J Equity Health. 2014;13:51. doi:10.1186/1475-9276-13-51.

35. Kondo N, Subramanian SV, Kawachi I, Takeda Y, Yamagata Z. Economic recession and health inequalities in Japan: analysis with a national sample, 1986-2001. J Epidemiol Community Health. 2008;62(10):869-75. doi:10.1136/ jech.2007.070334.

36. Hauksdottir A, McClure C, Jonsson SH, Olafsson O, Valdimarsdóttir UA. Increased stress among women following an economic collapse: a prospective cohort study. Am J Epidemiol. 2013;177(9):979-88. doi:10.1093/ aje/kws347.

37. Economou M, Madianos M, Peppou LE, Patelakis A, Stefanis CN. Majo depression in the era of economic crisis: a replication of a cross-sectional study across Greece. J Affect Disord. 2013;145(3):308-14. doi:10.1016/j.jad. 2012.08.008.

38. Madianos M, Economou M, Alexiou T, Stefanis C. Depression and economic hardship across Greece in 2008 and 2009: two cross-sectional surveys nationwide. Soc Psychiatry Psychiatr Epidemiol. 2011;46(10): 943-52. doi:10.1007/s00127-010-0265-4.

39. Gili M, Roca M, Basu S, McKee M, Stuckler D. The mental health risks of economic crisis in Spain: evidence from primary care centres, 2006 and 2010. Eur J Public Health. 2013;23(1):103-8. doi:10.1093/eurpub/ cks035.

40. Wang J, Smailes E, Sareen J, Fick GH, Schmitz N, Patten SB. The prevalence of mental disorders in the working population over the period of global economic crisis. Can J Psychiatry. 2010;55(9):598-605.

41. Lee S, Guo WJ, Tsang A, Mak AD, Wu J, Ng KL, et al. Evidence for the 2008 economic crisis exacerbating depression in Hong Kong. J Affect Disord. 2010;126(1-2):125-33. doi:10.1016/j.jad.2010.03.007.
42. Bor J, Basu S, Coutts A, McKee M, Stuckler D. Alcohol use during the great recession of 2008-2009. Alcohol Alcohol. 2013:48(3):343-8. doi:10.1093/ alcalc/agt002.

43. Munne Ml. Alcohol and the economic crisis in Argentina: recent findings. Addiction. 2005;100(12):1790-9. do::10.1111/j.1360-0443.2005.01248.x.

44. Garcy AM, Vagero D. Unemployment and suicide during and after a deep recession: a longitudinal study of 3.4 million Swedish men and women. Am J Public Health. 2013;103(6):1031-8. doi:10.2105/ajph.2013. 301210.

45. Economou M, Madianos M, Peppou LE, Theleritis C, Patelakis A, Stefanis C. Suicidal ideation and reported suicide attempts in Greece during the economic crisis. World Psychiatry. 2013;12(1):53-9. doi:10.1002/wps.20016.

46. Hong J, Knapp M, McGuire A. Income-related inequalities in the prevalence of depression and suicidal behaviour: a 10-year trend following economic crisis. World Psychiatry. 2011;10(1):40-4.

47. Lopez Bernal JA, Gasparrini A, Artundo CM, McKee M. The effect of the late 2000s financial crisis on suicides in Spain: an interrupted time-series analysis. Eur J Public Health. 2013;23(5):732-6. doi:10.1093/eurpub/ckt083.

48. Córdoba-Doña JA, San Sebastián M, Escolar-Pujolar A, Martínez-Faure JE, Gustafsson PE. Economic crisis and suicidal behaviour: the role of unemployment, sex and age in Andalusia, Southern Spain. Int J Equity Health. 2014;13:55. doi:10.1186/1475-9276-13-55.

49. Alameda-Palacios J, Ruiz-Ramos M, García-Robredo B. Suicidio, prescripción de antidepresivos y desempleo en Andalucía. Gac Sanit. 2014;28:309-12.

50. Pompili M, Vichi M, Innamorati M, Lester D, Yang B, De Leo D, et al. Suicide in Italy during a time of economic recession: some recent data related to age and gender based on a nationwide register study. Health Soc Care Community. 2014;22(4):361-7. doi:10.1111/hsc.12086.

51. Barr B, Taylor-Robinson D, Scott-Samuel A, McKee M, Stuckler D. Suicides associated with the 2008-10 economic recession in England: time trend analysis. BMJ. 2012;345, e5142. doi:10.1136/bmj.e5142.

52. Coope C, Gunnell D, Hollingworth W, Hawton K, Kapur N, Fearn V, et al. Suicide and the 2008 economic recession: who is most at risk? Trends in suicide rates in England and Wales 2001-2011. Soc Sci Med. 2014;117:76-85. doi:10.1016/j. socscimed.2014.07.024

53. Reeves A, McKee M, Stuckler D. Economic suicides in the Great Recession in Europe and North America. Br J Psychiatry. 2014;205(3):246-7. doi:10.1192/ bjp.bp.114.144766.

54. Reeves A, Stuckler D, McKee M, Gunnell D, Chang SS, Basu S. Increase in state suicide rates in the USA during economic recession. Lancet. 2012; 380(9856):1813-4. doi:10.1016/50140-6736(12)61910-2.

55. Davalos ME, French MT. This recession is wearing me out! Health-related quality of life and economic. J Ment Health Policy Econ. 2011;14(2):61-72.

56. Flint E, Shelton N, Bartley M, Sacker A. Do local unemployment rates modify the effect of individual labour market status on psychological distress? Health Place. 2013;23:1-8. doi:10.1016/j.healthplace.2013.04.004.

57. Strandh M, Novo M, Hammarström A. Mental health among the unemployed and the unemployment rate in the municipality. Eur J Pub Health. 2011;21(6):799-805.

58. Eichhorn J. Unemployment needs context: how societal differences between countries moderate the loss in life-satisfaction for the unemployed. J Happiness Stud. 2013;14(6):1657-80. doi:10.1007/s10902-012-9402-y.

59. Charles KK, Decicca P. Local labor market fluctuations and health: is there a connection and for whom? J Health Econ. 2008;27(6):1532-50. doi:10.1016/j.jhealeco.2008.06.004

60. Iglesias García C, Sáiz Martinez P, García-Portilla González MP, Bousoño García M, Jiménez Treviño L, Sánchez Lasheras F, et al. Effects of the economic crisis on demand due to mental disorders in Asturias: data from the Asturias Cumulative Psychiatric Case Register (2000-2010). Actas Esp Psiquiatr. 2014;42(3):108-15.

61. Norstrom T, Gronqvist H. The Great Recession, unemployment and suicide. J Epidemiol Community Health. 2015;69:110-6. doi:10.1136/jech-2014-204602.

62. Breuer C. Unemployment and suicide mortality: evidence from regional panel data in Europe. Health Econ. 2014;24(8):936-50. doi:10.1002/hec.3073.

63. Stuckler D, Basu S, Suhrcke M, Coutts A, McKee M. The public health effect of economic crises and alternative policy responses in Europe: an empirical analysis. Lancet. 2009;374(9686):315-23. doi:10.1016/s01406736(09)61124-7.

64. Toffolutti V, Suhrcke M. Assessing the short term health impact of the Great Recession in the European Union: a cross-country panel analysis. Prev Med. 2014;64:54-62. doi:10.1016/j.ypmed.2014.03.028. 
65. Reeves A, McKee M, Gunnell D, Chang SS, Basu S, Barr B, et al. Economic shocks, resilience, and male suicides in the Great Recession: cross-national analysis of 20 EU countries. Eur J Pub Health. 2015;25(3):404-9. doi:10.1093/ eurpub/cku168.

66. Baumbach A, Gulis G. Impact of financial crisis on selected health outcomes in Europe. Eur J Public Health. 2014;24(3):399-403. doi:10.1093/ eurpub/cku042

67. Mohseni-Cheraghlou A. Labor markets and mental well-being: labor market conditions and suicides in the United States (1979-2004). J Socio-Econ. 2013;45:175-86. doi:10.1016/j.socec.2013.05.003.

68. Phillips JA, Nugent CN. Suicide and the Great Recession of 2007-2009: the role of economic factors in the 50 U.S. states. Soc Sci Med. 2014;116:22-31. doi:10.1016/j.socscimed.2014.06.015.

69. Cylus J, Glymour MM, Avendano M. Do generous unemployment benefit programs reduce suicide rates? A state fixed-effect analysis covering 1968-2008. Am J Epidemiol. 2014;180(1):45-52. doi:10.1093/aje/kwu106.

70. Chan CH, Caine ED, You S, Fu KW, Chang SS, Yip PS. Suicide rates among working-age adults in South Korea before and after the 2008 economic crisis. J Epidemiol Community Health. 2014;68:246-52. doi:10.1136/jech2013-202759.

71. Antonakakis N, Collins A. The impact of fiscal austerity on suicide: on the empirics of a modern Greek tragedy. Soc Sci Med. 2014;112:39-50. doi:10. 1016/j.socscimed.2014.04.019.

72. Madianos MG, Alexiou T, Patelakis A, Economou M. Suicide, unemployment and other socioeconomic factors: evidence from the economic crisis in Greece. Eur J Psychiatr. 2014;28(1):39-49. http://dx.doi.org/10.4321/S021361632014000100004

73. Fountoulakis K, Savopoulos C, Siamouli M, Zaggelidou E, Mageiria S, lacovides A, et al. Trends in suicidality amid the economic crisis in Greece. Eur Arch Psychiatry Clin Neurosci. 2013;263(5):441-4. doi:10.1007/s00406012-0385-9.

74. Saurina C, Bragulat B, Saez M, López-Casasnovas G. A conditional model for estimating the increase in suicides associated with the 2008-2010 economic recession in England. J Epidemiol Community Health. 2013;67(9): 779-87. doi:10.1136/jech-2013-202645.

75. Fountoulakis KN, Gonda X, Dome P, Theodorakis PN, Rihmer Z. Possible delayed effect of unemployment on suicidal rates: the case of Hungary. Ann Gen Psychiatry. 2014;13:12. doi:10.1186/1744-859x-13-12.

76. Houle JN, Light MT. The home foreclosure crisis and rising suicide rates, 2005 to 2010. Am J Public Health. 2014;104(6):1073-9. doi:10.2105/AJPH. 2013.301774.

77. Mattei G, Ferrari S, Pingani L, Rigatelli M. Short-term effects of the 2008 Great Recession on the health of the Italian population: an ecological study. Soc Psychiatry Psychiatr Epidemiol. 2014;49(6):851-8. doi:10.1007/s00127-014-0818-z.

78. Berchick ER, Gallo WT, Maralani V, Kasl SV. Inequality and the association between involuntary job loss and depressive symptoms. Soc Sci Med. 2012; 75(10):1891-4. doi:10.1016/j.socscimed.2012.07.024.

79. Olesen SC, Butterworth P, Leach LS, Kelaher M, Pirkis J. Mental health affects future employment as job loss affects mental health: findings from a longitudinal population study. BMC Psychiatry. 2013;13:144. doi:10.1186/1471244x-13-144.

80. Thomas C, Benzeval M, Stansfeld S. Psychological distress after employment transitions: the role of subjective financial position as a mediator. J Epidemiol Community Health. 2007;61(1):48-52. doi:10.1136/jech.2005.044206.

81. McKenzie SK, Imlach Gunasekara F, Richardson K, Carter K. Do changes in socioeconomic factors lead to changes in mental health? Findings from three waves of a population based panel study. J Epidemiol Community Health. 2014;68(3):253-60. doi:10.1136/jech-2013-203013.

82. Steele F, French R, Bartley M. Adjusting for selection bias in longitudinal analyses using simultaneous equations modeling: the relationship between employment transitions and mental health. Epidemiology. 2013;24(5):703-11. doi:10.1097/EDE.0b013e31829d2479.

83. Flint E, Bartley M, Shelton N, Sacker A. Do labour market status transitions predict changes in psychological well-being? J Epidemiol Community Health. 2013;67(9):796-802. doi:10.1136/jech-2013-202425.

84. Kan M. Being out of work and health among younger japanese men: a panel data analysis. Ind Health. 2013;51(5):514-23. doi:10.2486/indhealth. 2013-0040.

85. Butterworth $\mathrm{P}$, Leach L, Pirkis J, Kelaher M. Poor mental health influences risk and duration of unemployment: a prospective study. Soc Psychiatry Psychiatr Epidemiol. 2012;47(6):1013-21. doi:10.1007/s00127-011-0409-1.
86. Milner A, Spittal MJ, Page A, LaMontagne AD. The effect of leaving employment on mental health: testing 'adaptation' versus 'sensitisation' in a cohort of working-age Australians. Occup Environ Med England. 2014;16774. doi: 10.1136/oemed-2013-101759.

87. Aslund C, Starrin B, Nilsson KW. Psychosomatic symptoms and low psychological well-being in relation to employment status: the influence of social capital in a large cross-sectional study in Sweden. Int J Equity Health. 2014;13:22. doi:10.1186/1475-9276-13-22.

88. Lindstrom M. Psychosocial work conditions, unemployment and selfreported psychological health: a population-based study. Occup Med (Lond). 2005;55(7):568-71. doi:10.1093/occmed/kqi122.

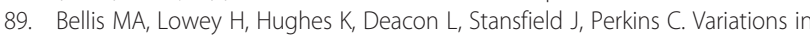
risk and protective factors for life satisfaction and mental well-being with deprivation: a cross-sectional study. BMC Public Health. 2012;12:492. doi:10. 1186/1471-2458-12-492.

90. Szwarcwald CL, Bastos Fl, Esteves MAP. State of animus among Brazilians: influence of socioeconomic context? Cadernos de Saúde Pública. 2005;21:S33-42

91. Riumallo-Herl C, Basu S, Stuckler D, Courtin E, Avendano M. Job loss, wealth and depression during the Great Recession in the USA and Europe. Int $J$ Epidemiol. 2014;43(5):1508-17. doi:10.1093/ije/dyu048.

92. Jefferis BJ, Nazareth I, Marston L, Moreno-Kustner B, Bellón JÁ, Svab I, et al. Associations between unemployment and major depressive disorder: evidence from an international, prospective study (the predict cohort). Soc Sci Med. 2011;73(11):1627-34. doi:10.1016/j.socscimed.2011.09.029.

93. Ford E, Clark C, McManus S, Harris J, Jenkins R, Bebbington P, et al. Common mental disorders, unemployment and welfare benefits in England. Public Health. 2010;124(12):675-81. doi:10.1016/j.puhe.2010.08.019.

94. Molarius A, Berglund K, Eriksson C, Eriksson HG, Lindén-Boström M, Nordström E, et al. Mental health symptoms in relation to socio-economic conditions and lifestyle factors: a population-based study in Sweden. BMC Public Health. 2009;9:302. doi:10.1186/1471-2458-9-302.

95. Pinto-Meza A, Moneta MV, Alonso J, Angermeyer MC, Bruffaerts R, Caldas de Almeida JM, et al. Social inequalities in mental health: results from the EU contribution to the World Mental Health Surveys Initiative. Soc Psychiatry Psychiatr Epidemiol. 2013;48(2):173-81. doi:10.1007/s00127-012-0536-3.

96. Snorradóttir Á, Vilhjálmsson R, Rafnsdóttir GL, Tómasson K. Financial crisis and collapsed banks: psychological distress and work related factors among surviving employees a nation-wide study. Am J Ind Med. 2013;56(9):1095-106. doi:10.1002/ ajim.22210.

97. Karjalainen $\mathrm{K}$, Lintonen T, Impinen A, Lillsunde P, Mäkelä P, Rahkonen O, et al. Socio-economic determinants of drugged driving: a register-based study. Addiction. 2011;106(8):1448-59. doi:10.1111/j.1360-0443.2011.03422.x.

98. Compton WM, Gfroerer J, Conway KP, Finger MS. Unemployment and substance outcomes in the United States 2002-2010. Drug Alcohol Depend. 2014;142:350-3. doi:10.1016/j.drugalcdep.2014.06.012.

99. Murphy RD, Zemore SE, Mulia N. Housing instability and alcohol problems during the 2007-2009 US recession: the moderating role of perceived family support. J Urban Health. 2014;91(1):17-32. doi:10.1007/s11524-013-9813-z.

100. Freyer-Adam J, Gaertner B, Tobschall S, John U. Health risk factors and selfrated health among job-seekers. BMC Public Health. 2011;11:659. doi:10. 1186/1471-2458-11-659.

101. Shim E, Cho Y. Widening social disparities in alcohol-attributable deaths among Korean men aged 40-59 years during the transitional period of the economic crisis (1995-2005). Int J Public Health. 2013;58(4):521-7. doi:10. 1007/s00038-013-0456-3.

102. Newman SC, Bland RC. Case-control study of unemployment and parasuicide. Compr Psychiatry. 2007;48(6):511-5. doi:10.1016/j.comppsych. 2007.06.002.

103. Borges G, Nock MK, Haro Abad JM, Hwang I, Sampson NA, Alonso J, et al. Twelve-month prevalence of and risk factors for suicide attempts in the World Health Organization World Mental Health Surveys. J Clin Psychiatry. 2010;71(12):1617-28. doi:10.4088/JCP.08m04967blu.

104. Milner A, Morrell S, LaMontagne AD. Economically inactive, unemployed and employed suicides in Australia by age and sex over a 10-year period: what was the impact of the 2007 economic recession? Int J Epidemiol. 2014;43(5):1500-7. doi:10.1093/ije/dyu148.

105. Miret M, Caballero FF, Huerta-Ramírez R, Moneta MV, Olaya B, Chatterji $\mathrm{S}$, et al. Factors associated with suicidal ideation and attempts in Spain for different age groups. Prevalence before and after the onset of the economic crisis. J Affect Disord. 2014;163:1-9. doi:10.1016/j.jad.2014.03.045. 
106. Sirvio A, Ek E, Jokelainen J, Koiranen M, Järvikoski T, Taanila A. Precariousness and discontinuous work history in association with health. Scand J Public Health. 2012;40(4):360-7. doi:10.1177/1403494812450092.

107. Virtanen $P$, Janlert U, Hammarström A. Exposure to temporary employment and job insecurity: a longitudinal study of the health effects. Occup Environ Med. 2011;68(8):570-4.

108. Giorgi G, Arcangeli G, Mucci N, Cupelli V. Economic stress in workplace: the impact of fear the crisis on mental health. Work. 2015;51(1):135-42. doi:10.3233/ wor-141844.

109. Butterworth P, Leach LS, McManus S, Stansfeld SA. Common mental disorders, unemployment and psychosocial job quality: is a poor job better than no job at all? Psychol Med. 2013;43(8):1763-72. doi:10.1017/ s0033291712002577.

110. Meltzer H, Bebbington P, Brugha T, Jenkins R, McManus S, Stansfeld S. Job insecurity, socio-economic circumstances and depression. Psychol Med. 2010;40(8):1401-7. doi:10.1017/s0033291709991802.

111. Sareen J, Afifi TO, McMillan KA, Asmundson GJ. Relationship between household income and mental disorders: findings from a population-based longitudinal study. Arch Gen Psychiatry. 2011;68(4):419-27. doi:10.1001/ archgenpsychiatry.2011.15.

112. Carter KN, Blakely T, Collings S, Imlach Gunasekara F, Richardson K. What is the association between wealth and mental health? J Epidemiol Community Health. 2009;63(3):221-6. doi:10.1136/jech.2008.079483.

113. Taylor MP, Pevalin DJ, Todd J. The psychological costs of unsustainable housing commitments. Psychol Med. 2007;37(7):1027-36. doi:10.1017/s0033291706009767.

114. McLaughlin KA, Nandi A, Keyes KM, Uddin M, Aiello AE, Galea S, et al. Home foreclosure and risk of psychiatric morbidity during the recent financial crisis. Psychol Med. 2012;42(7):1441-8. doi:10.1017/s0033291711002613.

115. Fone D, Greene G, Farewell D, White J, Kelly M, Dunstan F. Common mental disorders, neighbourhood income inequality and income deprivation: smallarea multilevel analysis. Br J Psychiatry. 2013;202(4):286-93. doi:10.1192/bjp. bp.112.116178.

116. Redonnet B, Chollet A, Fombonne E, Bowes L, Melchior M. Tobacco, alcohol, cannabis and other illegal drug use among young adults: the socioeconomic context. Drug Alcohol Depend. 2012;121(3):231-9. doi:10. 1016/j.drugalcdep.2011.09.002.

117. Meltzer $H$, Bebbington $P$, Brugha T, Jenkins R, McManus S, Dennis MS. Personal debt and suicidal ideation. Psychol Med. 2011;41(4):771-8. doi:10. 1017/s0033291710001261.

118. Solantaus T, Leinonen J, Punamaki RL. Children's mental health in times of economic recession: replication and extension of the family economic stress model in Finland. Dev Psychol. 2004;40(3):412-29. doi:10.1037/0012-1649.40.3.412.

119. Pfoertner TK, Rathmann K, Elgar FJ, de Looze M, Hofmann F, Ottova-Jordan $\checkmark$, et al. Adolescents' psychological health complaints and the economic recession in late 2007: a multilevel study in 31 countries. Eur J Public Health. 2014;24(6):961-7. doi:10.1093/eurpub/cku056.

120. Klanšček HJ, Ziberna J, Korošec A, Zurc J, Albreht T. Mental health inequalities in Slovenian 15-year-old adolescents explained by personal social position and family socioeconomic status. Int J Equity Health. 2014;13:26. doi:10.1186/1475-9276-13-26.

121. Borges A, Matos M, Diniz J. Estatuto familiar e autoperceção de saúde nos adolescentes. Temas em Psicologia. 2011;19(2):347-60.

122. Reinhardt Pedersen C, Madsen M, Kohler L. Does financial strain explain the association between children's morbidity and parental non-employment? J Epidemiol Community Health. 2005;59(4):316-21. doi:10.1136/jech.2003.013839.

123. Sleskova M, Salonna F, Geckova AM, Nagyova I, Stewart RE, van Dijk JP, et al. Does parental unemployment affect adolescents' health? J Adolesc Health. 2006;38(5):527-35. doi:10.1016/j.jadohealth.2005.03.021.

124. Rhodes $A E$, Lu H, Skinner R. Time trends in medically serious suicide-related behaviours in boys and girls. Can J Psychiatry. 2014;59(10):556-60.

125. Gassman-Pines A, Ananat EO, Gibson-Davis CM. Effects of statewide job losses on adolescent suicide-related behaviors. Am J Public Health. 2014; 104(10):1964-70. doi:10.2105/ajph.2014.302081.

126. Sargent-Cox K, Butterworth P, Anstey KJ. The global financial crisis and psychological health in a sample of Australian older adults: a longitudinal study. Soc Sci Med. 2011;73(7):1105-12. http://dx.doi.org/10.1016/j.socscimed.2011.06.063.

127. Cagney KA, Browning CR, Iveniuk J, English N. The onset of depression during the great recession: foreclosure and older adult mental health. Am J Public Health. 2014;104(3):498-505. doi:10.2105/AJPH.2013.301566.
128. Evans-Lacko S, Knapp M, McCrone P, Thornicroft G, Mojtabai R. The mental health consequences of the recession: economic hardship and employment of people with mental health problems in 27 European countries. PLoS One. 2013;8(7), e69792. doi:10.1371/journal.pone.0069792.

129. Ben Lakhdar C, Bastianic T. Economic constraint and modes of consumption of addictive goods. Int J Drug Policy. 2011;22(5):360-5. doi:10.1016/j.drugpo.2011.03.004.

130. Fitch C, Hamilton S, Bassett P, Davey R. The relationship between personal debt and mental health: a systematic review. Ment Health Rev J. 2011;16(4): 153-66. http://dx.doi.org/10.1108/13619321111202313.

131. Roelfs DJ, Shor E, Davidson KW, Schwartz JE. Losing life and livelihood: a systematic review and meta-analysis of unemployment and all-cause mortality. Soc Sci Med. 2011;72(6):840-54. doi:10.1016/j.socscimed.2011.01. 005.

132. Bradshaw J. Social exclusion, vulnerability \& disadvantage task group background paper 3: child poverty in the WHO European Region. Copenhagen. 2012.

133. Wahlbeck K, McDaid D. Actions to alleviate the mental health impact of the economic crisis. World Psychiatry. 2012;11(3):139-45.

134. Viner RM, Ozer EM, Denny S, Marmot M, Resnick M, Fatusi A, et al. Adolescence and the social determinants of health. Lancet. 2012;379(9826):1641-52. doi:10. 1016/S0140-6736(12)60149-4.

135. Eurostat. Children at risk of poverty or social exclusion-statistics explained. 2013.

136. WHO. Investing in mental health. Geneva: World Health Organization; 2003.

137. Cronin P, Ryan F, Coughlan M. Undertaking a literature review: a step-by-step approach. Br J Nurs. 2008;17:38-43.

138. Goldman-Mellor SJ, Saxton KB, Catalano RC. Economic contraction and mental health: a review of the evidence, 1990-2009. Int J Ment Health. 2010;39(2):6-31.

\section{Submit your next manuscript to BioMed Central and we will help you at every step:}

- We accept pre-submission inquiries

- Our selector tool helps you to find the most relevant journal

- We provide round the clock customer support

- Convenient online submission

- Thorough peer review

- Inclusion in PubMed and all major indexing services

- Maximum visibility for your research

Submit your manuscript at www.biomedcentral.com/submit
) Biomed Central 